PARALLELISM OF THE SOILS DEVELOPED ON THE GRAY DRIFTS OF MINNESOTA

UC-NRLF

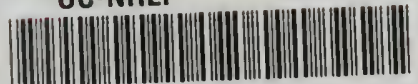

В $4523 \quad 670$

A THESIS SUBMITTED TO THE FACULTY OF THE GRADUATE SCHOOL OF THE UNIVERSITY OF MINNESOTA

BY

CLAYTON ORD ROST, B. Sc, M. A.

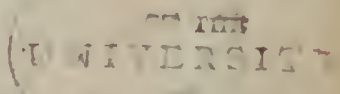

IN PARTIAL FULFILLMENT OF THE REQUIREMENTS FOR THE DEGREE OF DOCTOR OF PHILOSOPHY 

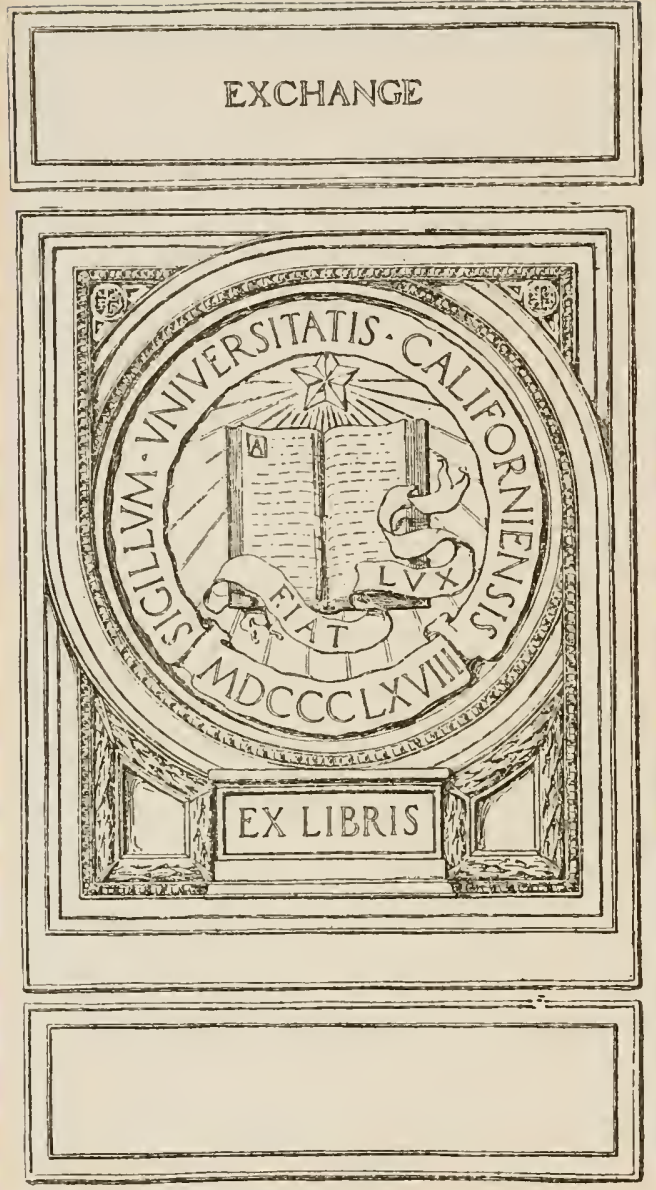


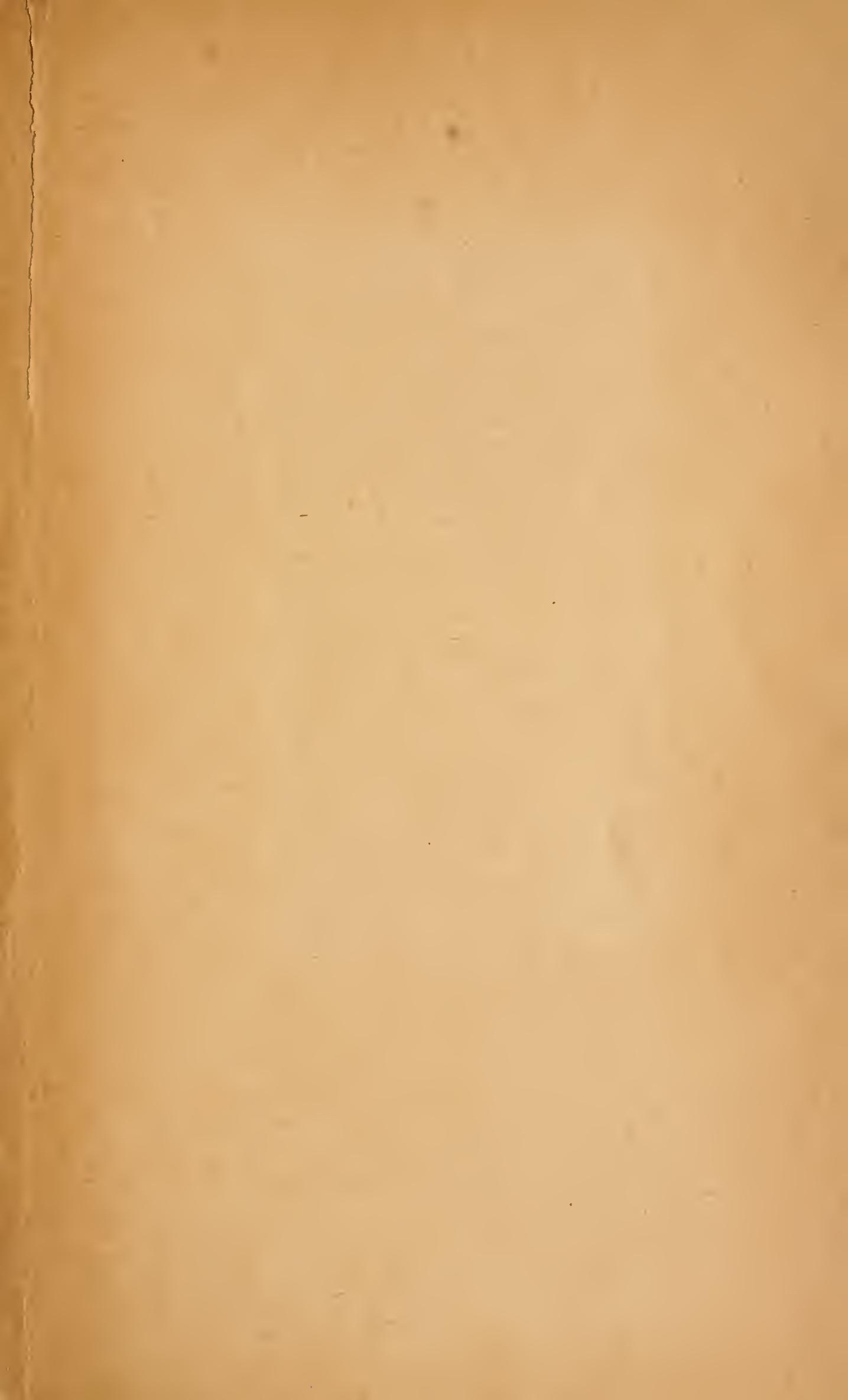





\title{
PARALLELISM OF THE SOILS DEVELOPED ON
} THE GRAY DRIFTS OF MINNESOTA

\begin{abstract}
A THESIS SUBMITTED TO THE FACULTY OF THE GRAdUATE SCHOOL OF THE UNIVERSITY OF MINNESOTA
\end{abstract}

$$
\text { BY }
$$

CLAYTON ORD ROST, B. Sc, M. A.

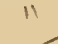

\begin{abstract}
IN PARTIAL FULFILLMENT OF THE REQUIREMENTS FOR THE DEGREE OF DOCTOR OF PHILOSOPHY
\end{abstract}




\section{ACKNOWLEDGEMENTS.}

The investigation reported in this thesis was undertaken at the suggestion of Dr. F. J. Alway, to whom the author is indebted for advice and assistance during its progress. Acknowledgement is also made to Mr. W. M. Shaw, who assisted in part of the analytical work. University of Minnesota,

C. O. R.

Division of Soils.

May 1, 1918. 
I.YTRONUCTION--

Page.

Soil formation............................. 5

Glacial history of Minnesota.................... 8

Advantages offered by area selected............... 10

Soil types studied........................... 11

Previous comparisons........................ 14

Studies in Illinois.......................... 14

Studies in Iowa......................... 16

Studies in Ninnesota...................... 17

FIELD MORK-

Selection of fields.......................... Is

Method of sampling......................... 19

EXPERIMENTAL-

A. Relative fineness of texture.................. 20

1. Proportion of coarse fragments... ........... 20

2. Texture of fine-earth................... 26

B. Lime Supply......................... 31

1. Carbonates ......................... 31

2. Reaction with litmus.................... 34

3. Reaction by the Truog method................ 35

4. Coloration of ammonia solution............... 37

5. Comparison of indications obtain ed by different methods .......................... 39

6. Relation of calcareousness to texture........... 40

7. Relation of carcareousness to age of drift....... 40

C. Inorganic Constituents-

1. Methods of analysis................... 41

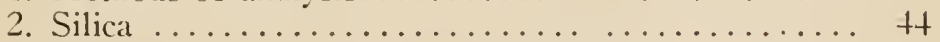

3. Iron ............................... 45

t. Alumina ............................... 45

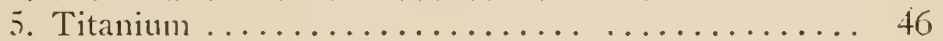

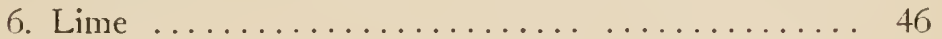

7. Magnesia ........................... 48

8. Phosphoric acid........................ 49

9. Potash $\ldots \ldots \ldots \ldots \ldots \ldots \ldots \ldots \ldots \ldots \ldots \ldots, 52$

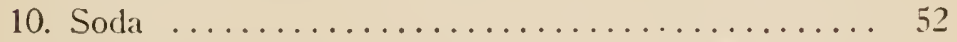

D. Organic Constituents--

1. Volatile matter ...................... 53

2. Organic carbon......................... 54

3. Nitrogen .......................... 54

E. Color ................................ 58

Classification of Rice County types according to the Russian system 62

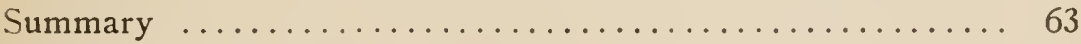

I.iterature Cited $\ldots \ldots \ldots \ldots \ldots \ldots \ldots \ldots \ldots \ldots \ldots \ldots \ldots$ 



\section{INTRODUCTION.}

Soil is to be defined as the superficial weathered layer of the solir earth-crust, the last including not only the solid rocks but also unconsolidated formations such as loess, dune-sands, and slacial deposits. Soils are variously defined, according to whether the particular writer is viewing them as the habitat of plants-the botanical viewpoint, or as simply the superficial geolorical formation-the geological viewpoint. Accordingly the depth of the superficial layer included inder the general designation "soil" varies from writer to writer, the gcologist often taking for this a higher value than the botanist. The latter will consider it to extend at least as deep as plant roots penetrate, and the former as deep as the composition of the parent rock may have been affected by percolating water, aided more or less by organisms or their products.

As the common farm crops in sonthern Mimnesota derive not only their mineral constituents but also their supply of water chiefly from the first three feet and almost exclusively from within the first five feet, we scarcely need to consider the portion below the fifth foot. As most of the crops draw more or less upon the third foot for these. and hence the whole of the first three foot section is to be considered as well within the root zone so that a study of the soil should include sections to at least this depth.

The great majority of Minnesota soils are glacial in origin and. for the most part, developed upon the massorted glacial till left behind by five separate and distinct ice sheets. Under these circumstances one of the first fuestions occurring to a soil investigator in this state is as to what relation, if any, exists between the character of the soils upon the various glaciations and the age of the latter. The object of the investigation reported in this thesis was to answer the quuestion in part.

\section{Soil Formation.}

The surface three feet or so of a freshly exposed lake-bed, recently formed sand-dume, till-plain or terminal moraine just exposed by a retreating glacier, is not to be considered as soil but as the parent rock upon which soils maty be developed by the combined agencies of living organisms and the products resulting on the death of these, and of percolating or descending waters, these carrying carbonic acid, soluble salts and organic componnds.

The form of alteration in the parent rock that will be induced by the soil-forming agencies will depend upon the vegetative covering, the temperature, the precipitation, the rate of evaporation, and the level 
of the ground water, as well as upon the perviousness to descending water of the parent rock and the water retaining capacity of its superficial portion. The vegetative covering, in its turn, is largely determined by the cliaracter of the parent rock or of the soil developed upon this, together with the climate of the locality. Hence, the properties of the parent rock and the climate of the region in which it happens to be exposed will together determine the relative importance of the various soil-forming agencies and accordingly, the character of the resulting soil.

In general the character of a soil is much more dependent upon the climate of the region in which it is found than upon the nature of the parent rock, or upon the manner of its formation. Thus a granite, a wind-laid silt loam and a lacustral clay may weather to produce soils of a very siniliar character when all three have been exposed to the same climate for a sufficient length of time, while soils of an entirely different character might arise on these same formations under other climatic conditions (2, p. 199).

Accordingly, as the climate of the earth shows a zonal distribution. the soil, unlike any other geological formation, also shows a zonal distribution, similar zones appearing in regular order on the different continents and in both hemisplieres (15, map 2 ) as we pass from the equator poleward, or, in a tropic or temperate region, ascend a high mountain (16, p. 343). Thus, desert soils in the United States resemble desert soils in Africa or Asia and the black prairie soils of the United States resemble the Chernozem of European Russia and Siberia (16, p. $286 ; 2$, p. $231 ; 4$, p. 423) and the pampas soils of Argentina (16, p. 44 and 114). If one but knows the climate of a region the general character of the soils can be predicted.

Where the character of the parent rock, its chemical composition or its physical properties, have been such as to leave upon the resulting soil an impression not overshadowed by the climate the soil is, according to Glinka, to be designated Endodynamomorphic but otherwise as Ektndynamomorphic $(16$, p. $35 ; 27$, p. 559). It is with the latter group of soils that the present study is concerned and these may be dividerl into six classes.

1. Soils formed where the mean temperature is high and the precipitation very high or fairly high.

The most of the organic material decays rapidly, causing a low proportion of this in the soil, and the salts resulting from the decay and the weathering of the silicates are completely leached out. The silicic acid derived from the weathering of silicates and alumino-silicates is leached out along with the alkali and alkali earth metals, leaving behind, in arldition to the quartz, the alumina, ferric oxide and titanium oxicle.

The laterites (title-colored soils 10, p. 440) of the moister, and the Red Earths of the drier portions of the tropics belong to this class. 
The yellow soils of southern France $(27$, p. 600) and of Japan are related to the Red Earths, the removal of the silica being charcteristic of only the later stages as in the laterites. In the latter, in various places, the concentration has proceeded so far as to make such soils serve as a source of metallic iron, really as a low gratle ore.

\section{Soils wherc the precipitation is lower and the temperature} much lower than in the preceling, as over northwestern and western Europe and in the United States east of the Mississippi river.

The soluble salts are leached out, the carbonates removed from the upper layer, and a certain amount of iron transported from the upper to the lower layers (27, p. 554). Only part of the organic matter is lost rapidly, thus permitting the accumulation of a comparatively large amount in the upper layers. In the colder, moister regions there resuit podsols, characterized by a whitish or gray horizon near the surface with a concentration of iron at a greater depth and a markedly acid reaction. Along witl the iron, manganese, calcium, magnesium, potassium and sodium more or less phosphoric acid is leached out of the upper layers and redeposited with the iron and manganese at a lower horizon $(15$, p. 78$)$. Where the temperature is higher, either degraded chernozems, brown earths or gray forest soils develop. These show less translocation of iron and little or none of phosphoric acid. Both the true podsols and the brown or gray forest soils develop under forest conditions.

III. Soils formed where the precipitation, ezaporation, temperature and topographical conditions canse a grassland i'egetation to hold its own against the forest.

The abundant growth of grasses exhausts the soil moisture supply and causes a delayed decomposition of their remains with the result that the organic matter content of the soil is higl. The plants, being chiefly annuals, biennials, or short-lived peremnials, frequently contribute both root and stem, as well as leaf, to the soil forming agencies and the organic matter is increased as deeply as the roots penetrate. Alkali salts are removed and the carbonates largely leached out of the upper layers are deposited, for the most part, in the base of the zone of maximum root pentration. Gypsum is recleposited at a still lower level, if at all. Alkali salts and carbonates formed by the action of carbon dioxide upon the silicates behave like the original soluble salts and carbonates, while the resulting silicic acid remains in the upper layers (2, p. 315). The class includes the Black Earths or Chernozems of Russia and the black and part of the brown prairie soils of the United States and Canada (21, p. 207 and 338). 


\section{Soils of the semi-arid or arid regions with a short grass or desert vegetation.}

The content of organic matter is lower than in the preceding group. Little or no percolation occurs. The movement of mineral constituents is confined to a concentration of carbonates and soluble salts just beyond or near the root tips in the drier regions and to the removal of only the soluble salts in the moister. This condition is found on the Great Plains of the United States and Canada and on the Steppes of Russia (16, p. 132).

$V$. Soils formed under excess of moisture. the upper soil horizon being saturated with water the most of the time.

Organic matter being unable to decay accumulates, iron is present largely as ferrous salts, and pyrites is formed. Where there is no outlet for the water evaporation will cause an accumulation of gypsum and carbonates near the surface if these are present in surrounding higher-lying soils. Peat, muck and marsh-meadow soils belong to this group.

\section{Y. Alkali soils.}

These form in both the third and fourth zones in places where water accumulates periodically and then escapes by evaporation, there being little or no loss by seepage or run-off $(18$, p. 103), or where water rises from a water table close to the surface and evaporates so rapidly that the percolation following rains does not counter-balance the ascent of soluble salts.

\section{Glacial History of Minnesota.}

The whole of the state of Minnesota, with the exception of a very small area in the extreme southeastern corner, has, at one time or another been glaciated (23 p. 16), the mantle of glacial material left behind constituting the parent rock of most of its soils. The study of the deposits left behind by the receding ice has shown that they are the result of successive glaciations, some of the ice sheets having radiated from centers east of James Bay and being designated the Labradorian, and the others from north or northwest of Minnesota and being referred to as the Keewatin. While some of the ice sheets from different centers may have been contemporaneous, or the one may have followed almost immediately after the other, in most cases each of the advances of ice after the first was so widely separated in time from its immediate predecessor that under the milder climate prevailing the earlier deposit had had soils developed upon it and drainage channels fully formed. The succeeding invasion then planed off the hilltops, filled up the valleys and buried the remaining portion of the earlier drift sheet. In those cases where one of the later ice sheets did not extend as far as the earlier, there is offered an opportunity for a conparison of the soils formed on the two. 
The drift naterial carried into Minmesota and left bohind by the inelting ice was picked up between the center from which the glacicr radiated and the northern borler as well as along its course across the state. In the case of the later ice shects glacial debris left by the earlier invasions was to a greater or less extent incorporated in the mass of fresh material brought by the advancing icc, a factor which complicates such a comparison as that mentioned above.

From eleven to thirtecn successive stages of the glacial period are generally recognized as applying to the United States (13, p. 383). These are as follows, the most recent (XIII) being given first and the oldest last (I).

XIII-The Champlain sub-stage (marine).

XII-The glacio-lacustrine sub-stage.

XI-The later Wisconsin, the sixth advance.

$\mathrm{X}$-The fifth interval of deglaciation, as yet unnamed.

IX-The Earlier VVisconsin, the fifth invasion.

VIII-The Peorian, the fourth interglacial interval.

VII-The Iowan, the fourth invasion.

VI-The Sangamon, the third interglacial interval.

$\mathrm{V}$-The Illinoian, the third invasion

IV-The Yarmouth, or Buchanan, the second interglacial interval.

III-The Kansan, or second invasion now recognized.

II-The Aftonian, the first known interglacial interval.

I-The Sub-Aftolian, or Jerseyan, the earliest known invasion.

There is some doubt as to the existence of the Iowan. The late Professor Calvin and members of the Iowa Geological Survey have regarded this as a distinct stage of glaciation but little older than the Wisconsin. Leverett (22, p. 282) was at first inclined to regard this as possibly of Illinoian age but has later come to consider it as part of the Kansan. In this case the Sangamon and the Peorian interglacial intervals would he iclentical. In the present thesis the views of Leverett are accepted.

Of the six glacial invasions five crossed what are now the borders of this state $(22$, p. $248 \mathrm{ff} ; 13$, p. $382 \mathrm{ff})$. The first of these was the Pre-Kansan, or Nebraskan, which corresponds to the Sub-Aftonian. This radiated from the Keewatin field and covered the greater part of the state but none of the drift is now naturally exposed in Minnesota, it having been entirely buried by the following invasions and being now encountered only in the deeper wells.

The second ice shect to reach Minnesota, the Kansan (Fig. 1), also radiated from the Keewatin field, covering every part of the state either previously or subsequently glaciated. The mantle left behind is designated as the Old Gray Drift and is still exposed in parts of Dakota, 
Rice, Dodge, Olmstead, Goodhue, Mower, Fillmore, Pipestone and Rock counties. Its presence in the last two counties named was not recognized by glacial geologists until after the field work in this study had been completed.

The Illinoian, the third to reach the state, covered only a small area in Washington county and the greater part of Dakota county. It came from a Labradorian center and over-rode the Kansan. The till left behind is designated the Old Red Drift.

The fourth advance of the ice into Minnesota, the Early Wisconsin, approached from the northeast and covered a considerable area to the west and southwest of Lake Superior (Fig. 1) and left a mantle of till known as the Young Red Drift. These two ice sheets crossing highly ferruginous rock formations gathered up portions of these and, consegtently, the soils developed upon the till show a distinctly red color.

The fifth ice sheet, the Late IVisconsin, which brought the Late Gray Drift, radiated from a Keewatin center to the north or slightly to the northwest of Minnesota and covered a much larger portion of the state (Fig. 1) than either of its immediate predecessors. This younger formation in contrast to the Old Gray Drift is characterized by numerous lakes and poorly drained areas such as the deposits older than the Young Red Drift do not possess. Fully developed drainage lines are to be found only where they were formed by the out-rushing water from the melting ice.

In addition to the Des Moines Lobe of the Late Wisconsin there was a contemporaneous Superior Lobe in which the ice advancing up to the bed of Lake Superior spread to the north, northeast, east and southeast. The till, almost free of limestone, was derived from crystalline rocks and, like the Illinoian and early $\mathrm{W}$ isconsin in Minnesota, has a red color.

Each period of glaciation was separated from the succeeding one by an interglacial interval which, in some cases, was very long, probably much longer than the time which has elapsed since the Late Wisconsin. The successive stages appear to have become shorter, the earlier being much longer than the later ones (13, p. 382).

\section{Advantages Offered by Area Selected.}

Rice connty in southeastern Minnesota offered the best site in the State for a study of the influence of the age of a glaciation upon the character of the soils. The earliest glaciation from which any till remains uncovered by later deposits, the liansan, covered the whole of what is now included in the county boundaries while the most recent of all the glaciations, the Late Wisconsin. covered only the western two-thirds and no intervening ice shects lad entered the area, except possibly the Early. Wisconsin at the very edge on the north (Fig. 1) 


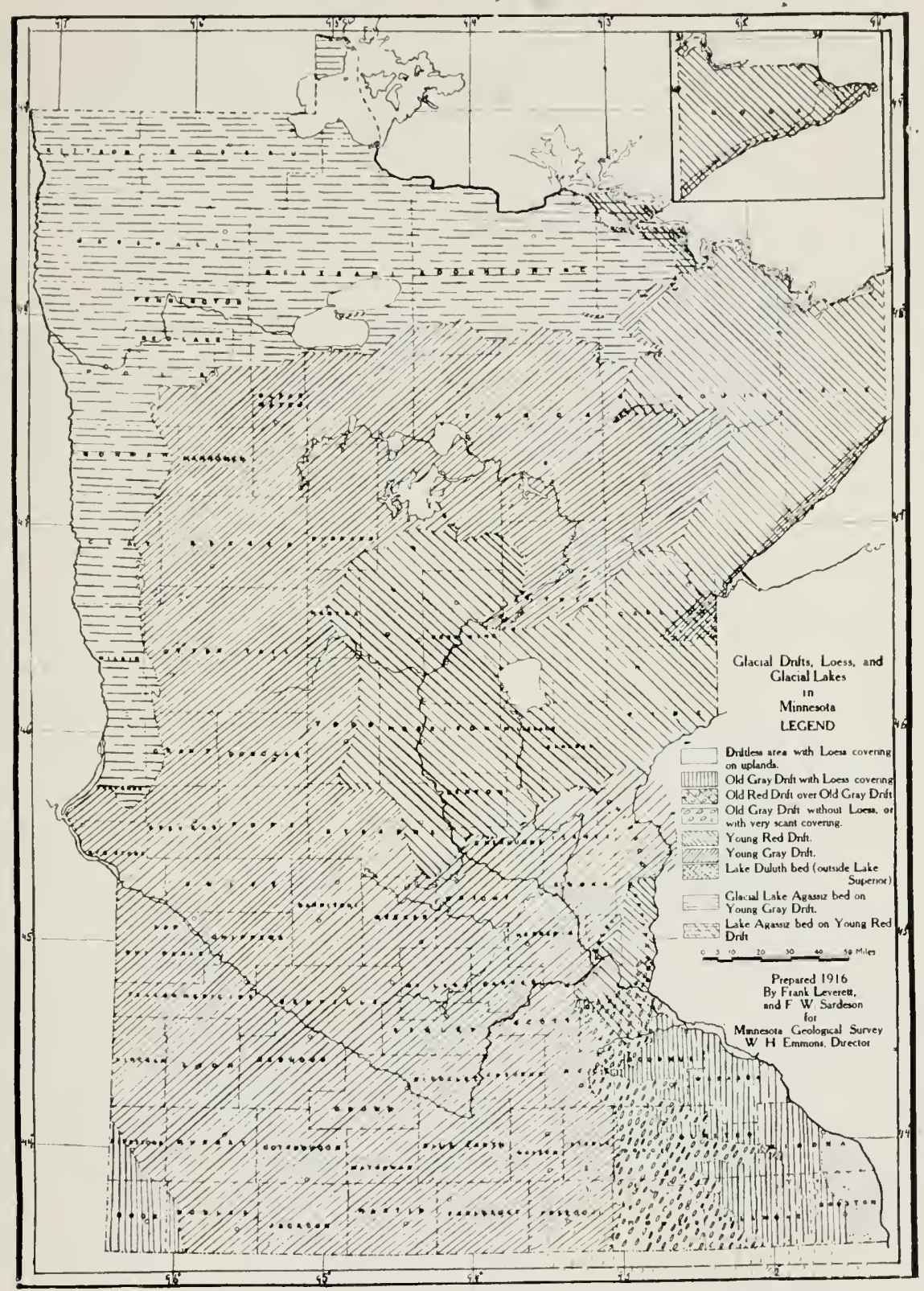

FIG. 1.-Map of Minnesota showing surface formations. (By Leverett. F., and Sardeson, F. W., .Winn. Geol. Suricy Bul. No. If, p. I3.) 


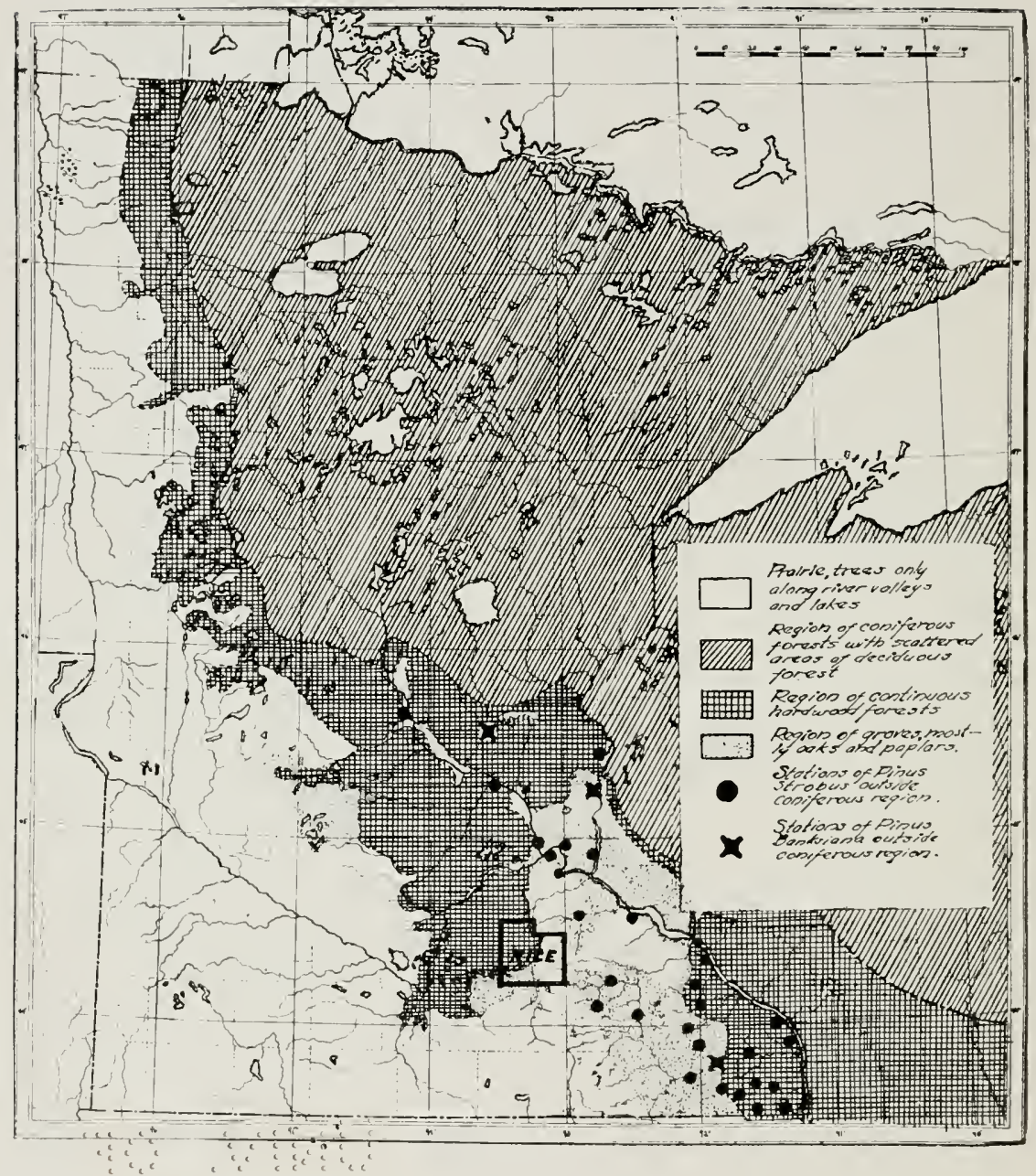

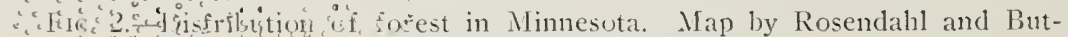
ters "ithe Plant II orld, Fol, $2 I$, No. 5. P. III). 
A long period of tine, including several epochs of glaciation as weit as long interglacial periods, in which floras and faunas were developed, elapsed between the two. Both glaciers radiated from Keewatin centers and accordingly brought along with then similar material, the chief characteristic of which was an abundance of limestone fragments.

Thus we have in Rice connty, side by sirle, the soils developed on the oldest exposed and those on the very youngest of the glacial formations, both, since the melting of the last ice-sheet, subjected to the same climatic influences and exposed to the same soil forming agencies.

For such a study it is highly desirable to be able to compare soils formed under different vegetation conditions, e. g., forest soils on the earlier drift with forest soils on the later. the natural grassland soils on the former with natural grassland soils on the latter. Rice is the only county in which this is possible, the other comnties in which the two selected drifts occur side by side being south of the limit of the forest (Fig. 2).

Further, for Rice county there was available a letailed soil surrey by the United States Bureau of Soils made in 1909) and published in 1911 (11) while Leverett, who was completing a detailed study of the glacial history of the state, kindly macke a detailed denarcation of the eastern boundary of the Late IVisconsin glaciation within the county, this having not yet been reported in printed form.

In the survey by the Burean of Soils the two drifts exposed on the surface are mentioned (11, p. 21-23), Leverett having personall: indicated the boundaries to the surveyors but no attempt was made by the latter to differentiate types in respect to the two drifts although it is stated $(11$, p. 21) that "the limestone from which much of this drift (Kansan) is derived, has long since given way to the agencies of weathering and only the more resistant rocks are left, whereas in the Wisconsin drift limestone and shales in addition to numerous cherty and crystalline rocks are very common." Fonrteen types of soil were mapped, of which three of the most extensive, viz., Carrington silt loam, Fargo silt loam, and Carrington loam, have representative areas on both drifts.

Thus Rice County offered an exceptional opportunity not only for the study of the differences in the mechanical, chemical and petrograhical composition resulting from the difference in age of the drift and the conseguent longer-continted leaching on the one than on the other, but also to determine whether soil classification as applied by the United States Bureau of Soils properly recognizes differences between soils on different drifts.

\section{Soil Types Studied.}

()nly four soil types are dealt with in the present studly, viz.. Carrington silt loam, Fargo silt loam, Carrington loam and Marshali silt loam. A soil type, as the term is employed by the U. S. Bureau of Soils (12, p. 11), is the unit of classification and is defined as including all soils that are alike agriculturally, or as nearly alike as it is possible to determine by field methods. 
The type name results from combining the class name of the surface material with the series name (Fargo, Carrington, etc.). The class (loam, silt loam, clay, etc.) is determined by the texture of the surface soil, the portion encountered by tillage implements, as decided upon in the field by the experienced surveyor and later confirmed in the laboratory by mechanical analysis of typical samples. The series name, as it serves as a key to all the important properties of the type except the texture of the surface stratum, is based upon the color and content of organic matter in both surface soil and subsoil, the subsoil profile, the topography, the origin and the mode of formation as well as any prominent chemical differences. insofar as they are likely to affect agricultural practice. A series includes all the types that differ from one another only in the texture of the surface stratum. The total number of series in the United States so far recognized by the Bureau of Soils amounts to about 600 and the types to a little in excess of 1.650 .

The soils of the Carrington series are derived from the weathering of the glacial drift. Carrington loam occupies the rolling uplands, is generally well drained and originally was nearly all covered with deciduous forest-the Big Woods. Carrington silt loam is confined almost entirely to those higher-lying portions of the county which were originally covered by prairie. On the Wisconsin the drainage is good, while on the Kansan it is much poorer than that of the Carrington loam. Boulders, some very large, occur in small numbers on both.

The Carrington loam is described $(11$, p. 22-23) as "a brownish black or yellowish brown silty loam, 12 to 24 inches deep, grading into a heavy yellow clay, which usually exceeds a depth of 15 feet. The texture of the surface soil is for the most part uniform, but the color and depth are variable. A depth of 15 inches is more typical than either of the extremes. There are few stone fragments in the material to a depth of three feet, though these increase in quantity with depth."

The Carrington silt loam (11, p. 26) is "a grayish-black or black heary silty loam, with a deptl of 15 inches, grading into a drab or brownish silty clay which at about 24 inches is underlain by dark yellow clay. The soil is senerally uniform in texture and has a high content of organic matter."

The Fargo silt loam is described $(11$, p. 32) as "a black clay or silty clay loam from 10 to 15 inches deep, grading into a dull colored clay which at 20 to 30 inches changes to a yellow and gray plastic clay. Beneath this there ustually occurs a thin layer of sand, sandy clay or gravel. In the southeast corner of the county the Fargo silt loam occupies a part of the original plain of the Kansan drift, but elsewhere it is a bottom-land type. The topography is generally level but is characterized by very gentle slopes as it approaches sloughs and streams. The areas are generally poorly drained and water is often found within the 3 -foot section in the bnttoms."

"The soil material along the sloughs has been washed from the 

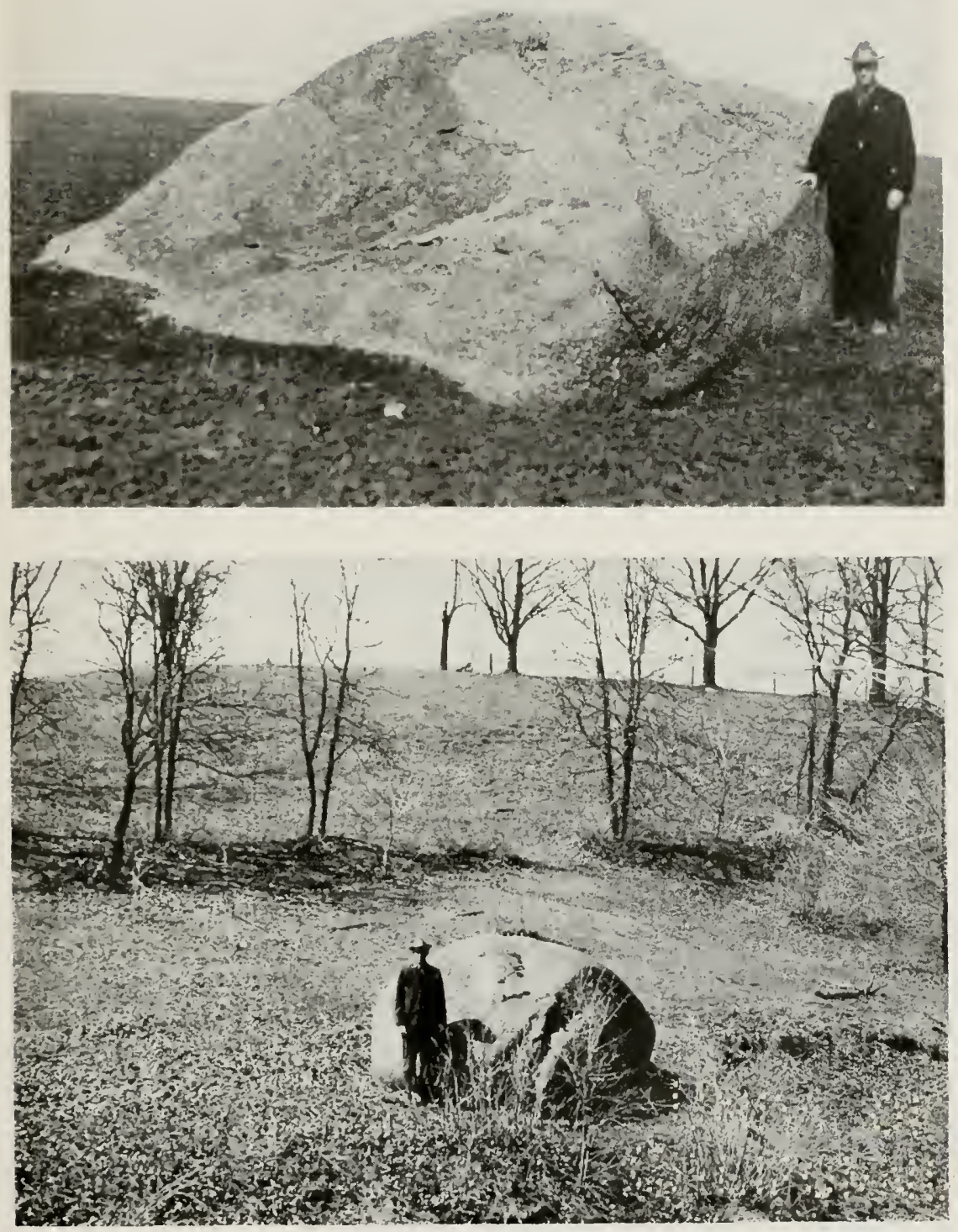

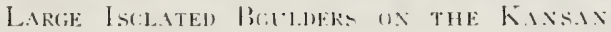

1. Pegmatite. Nirth of Nerstrand.

2. Cranite, near Field $1 / 1$ on Carrin! ton fosm. 
I'I.I'T: I
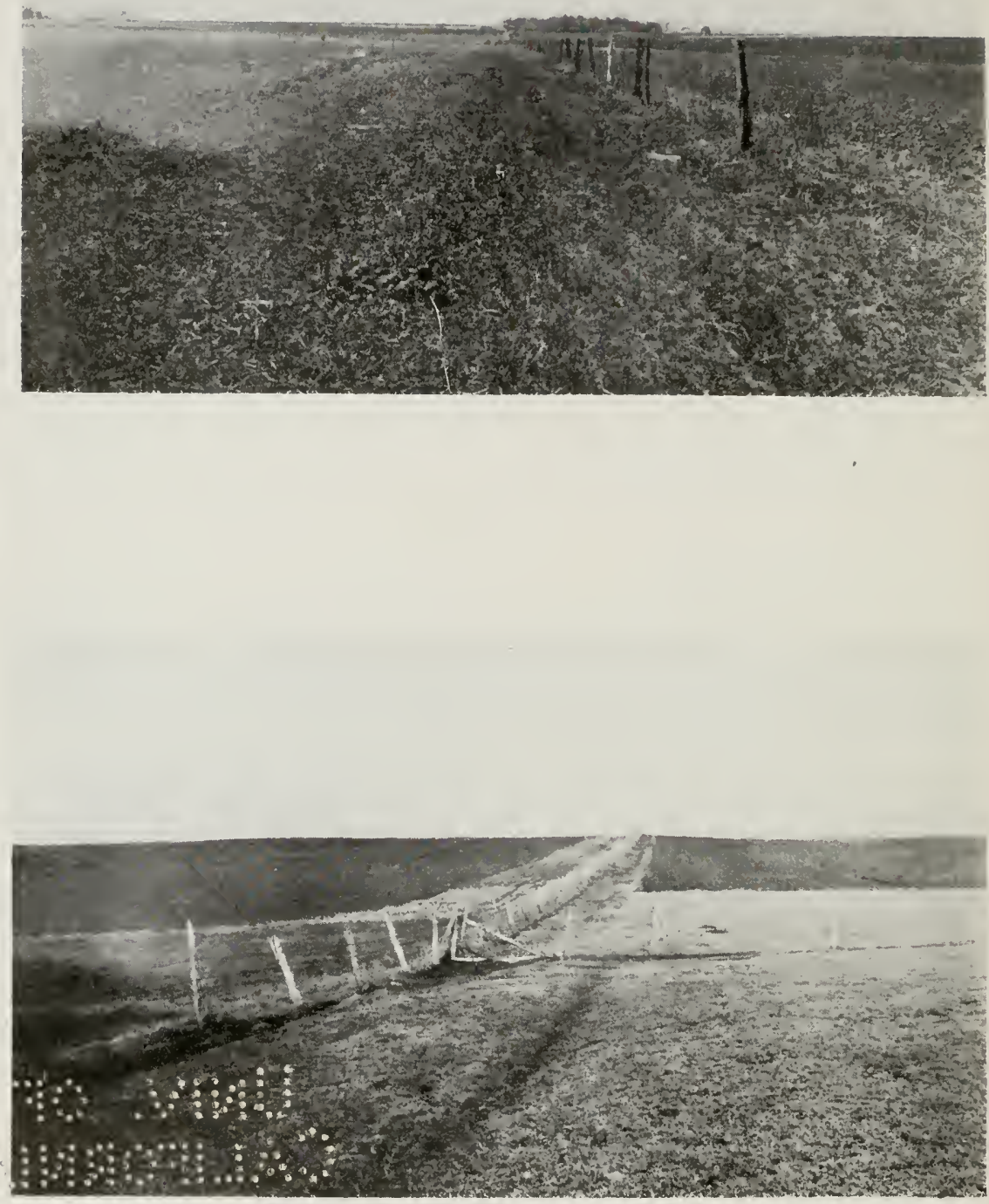

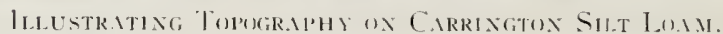

1. Field $V^{\top}$-en the Kansan.

2. Field $\mathrm{V}$-on the Late Wisconsin. 
inigher slopes and has accumulated faster than the sluggish streams can remove it. Some of the type, however, is lacustrine in origin, having, been deposited in shallow hasins or ponds. A very small part of it can be attributed to stream and river overflows." ()riqually it was almost exchusively grass-land.

Varshall loam, kesisnated Marshall silt loam in (o)mties more rescently surveved, is derived from the weathering of loess deposits (11, p. 35). The surface soil is a yellowish brown or brown silty loam to 6 or 12 inches, under which is a compact vellow silty loam and under this, at a deptl varying from 2f to 36 inches, a loose incoherent silty material lighter in color. The loess deposit varies from a few inches to 15 feet in thickness and in this county is underlain by glacial material.

The mechanical composition of typical samples from the county reported by Burke and Kolbe (11) is given in table 1 . These show the Carrington loam to be coarser in texture than the three silt loams, having considerably less of particles as fine or finer than very fine sand and accordingly more of the coarser fractions. The finer fractions: of the silt loams constitute from 81.6 to $9+$ per cent of the surface soil and from 68.9 to 91.4 per cent of the subsoil, while for the loan they form only 76.2 and 68.5 per cent for soil and subsoil, respectively. The mechanical composition of the subsoil of the Fargo silt loam is very similiar to that of the Carrington loam.

Table I.-Mechanical composition of typical samples from Rice County, as reported by Burke and Kolbe.

\begin{tabular}{|c|c|c|c|c|c|c|c|c|}
\hline ratum & $\begin{array}{l}\text { Fine } \\
\text { gravel }\end{array}$ & $\begin{array}{l}\text { Coarse } \\
\text { sand }\end{array}$ & $\begin{array}{l}\text { Medium } \\
\text { sand }\end{array}$ & $\begin{array}{l}\text { Fine } \\
\text { sand }\end{array}$ & $\begin{array}{l}\text { Very fine } \\
\text { sand }\end{array}$ & Silt & Clay & $\begin{array}{c}\text { Computed } \\
\text { Moist. equiv. } \\
\text { By B\&SI By A\&R2 }\end{array}$ \\
\hline
\end{tabular}

\section{Carrington Loam.}

\begin{tabular}{|c|c|c|c|c|c|c|c|c|c|}
\hline $\begin{array}{l}\text { Soil } \\
\text { Subsoil }\end{array}$ & $\begin{array}{l}0.7 \\
1.1\end{array}$ & $\begin{array}{l}4.0 \\
6.4\end{array}$ & $\begin{array}{l}5.1 \\
6.7\end{array}$ & $\begin{array}{l}13.8 \\
16.8\end{array}$ & $\begin{array}{r}9.9 \\
14.4\end{array}$ & $\begin{array}{l}49.0 \\
36.5\end{array}$ & $\begin{array}{l}17.3 \\
17.6\end{array}$ & $\begin{array}{l}29.7 \\
27.4\end{array}$ & $\begin{array}{l}27.1 \\
24.5\end{array}$ \\
\hline \multicolumn{10}{|c|}{ Cirrington Silt Loin. } \\
\hline $\begin{array}{l}\text { Soil } \\
\text { Subboil }\end{array}$ & $\begin{array}{l}0.0 \\
0.0\end{array}$ & $\begin{array}{l}1.2 \\
2.3\end{array}$ & $\begin{array}{l}1.6 \\
2.2\end{array}$ & $\begin{array}{l}2.8 \\
3.8\end{array}$ & $\begin{array}{l}18.8 \\
30.9\end{array}$ & $\begin{array}{l}62.3 \\
39.7\end{array}$ & $\begin{array}{l}12.9 \\
20.8\end{array}$ & $\begin{array}{l}27.7 \\
31.3\end{array}$ & $\begin{array}{l}27.1 \\
27.3\end{array}$ \\
\hline \multicolumn{10}{|c|}{ Fargu Silt Loam. } \\
\hline $\begin{array}{l}\text { Soil } \\
\text { Subsoil }\end{array}$ & $\begin{array}{l}0.0 \\
1.9\end{array}$ & $\begin{array}{l}3.3 \\
6.2\end{array}$ & $\begin{array}{l}4.2 \\
7.0\end{array}$ & $\begin{array}{r}9.4 \\
15.6\end{array}$ & $\begin{array}{r}4.9 \\
10.1\end{array}$ & $\begin{array}{l}65.0 \\
39.8\end{array}$ & $\begin{array}{l}13.1 \\
19.0\end{array}$ & $\begin{array}{l}28.4 \\
29.5\end{array}$ & $\begin{array}{l}28.0 \\
26.5\end{array}$ \\
\hline \multicolumn{10}{|c|}{ Marshall Silt Ioam. } \\
\hline Soil ... & $\begin{array}{l}0.1 \\
0.0\end{array}$ & $\begin{array}{l}1.7 \\
1.5\end{array}$ & $\begin{array}{l}4.6 \\
4.9\end{array}$ & $\begin{array}{l}12.1 \\
10.0\end{array}$ & $\begin{array}{l}10.6 \\
38.9\end{array}$ & $\begin{array}{l}50.5 \\
26.4\end{array}$ & $\begin{array}{l}20.5 \\
17.9\end{array}$ & $\begin{array}{l}33.2 \\
25.7\end{array}$ & $\begin{array}{l}28.6 \\
24.3\end{array}$ \\
\hline $\begin{array}{l}\text { Lower } \\
\text { Subsoil }\end{array}$ & 0.0 & 1.0 & 5.0 & 13.3 & 25.0 & 42.4 & 13.2 & 24.1 & . \\
\hline
\end{tabular}

1. Briggs and Shantz.

2. Alway and Russell.

The great amount of time consumerl by a mechanical analysis pre- 
vents it being exclusively employed in survey work. Certain physical constants, viz., the hygroscopic coefficient and the moisture equivalent, are dependent upon the mechanical composition and express in a singlevalued term the relative fineness of texture and have the additional advantage of being readily determined. Briggs and McLane (6, p. 20-21) and Briggs and Shantz (8, p. 73) have proposed the formulasHygroscopic coefficient $=0.0007$ sand +0.082 silt +0.39 clay and, Moisture equivalent $=0.02$ sands +0.22 silt +1.05 clay. Alway and Rost (4, p. 10), working on the relation of the hygroscopic co-efficient of loessial soils to the mechanical composition, have pointed out that no one formula for such a physical constant will do for all soils but that as an approximation for the loess soils that they were dealing with the above will serve.

Similarly Alway and Russel (5, p. 842) dealing with the moisture equivalents of the same soils have developed the formula: Moisture equivalent $=0.14$ sands +0.27 silt +0.53 clay. The moisture equivalents as calculated by these two formulas are shown in columns 9 and 10 of table 1 . The results obtained by the two formulas are very similar.

\section{Previous Comparisons.}

A limited amount of data showing the relations of the chemical composition of glacial soils to the age of the drift upon which the occur is already available, but none of the studies were made under conditions so favorable as those existing in Rice county. Hopkins and Pettit (20) in Illinois, Brown (9) in Iowa, and McMiller (25) in Minnesota have eaclı reported a study.

Hopkins and Pettit's study was based upon Leverett's drift surveyof Illinois in which six glaciations had been mapped. A considerable number of samples were collected from three depths on each, 0-7, 7-20, and 20-40 inches, and subjected to analysis for nitrogen, carbon, potassium and phosphorus. The averages for the different drift sheets are summarized in table 2.

As the glacial soils of Illinois are generally covered by a layer of loess from 3 to 10 feet or more in depth (20 p. 193) the samples were not of till but of the overlying mantle, and the age of the latter is not necessarily similar to that of the former. Hopkins and Pettit appear to have assumed that after each glaciation the freshly exposed till became quickly covered with its mantle of loess, this being derived from the till sheet, a portion of which it covered, and that the loess deposited on the later till sheets was derived chiefly from these and did not affect the soils on the earlier glaciations. There appears no satisfactory evidence that these assumptions are justified and hence it is doubtful just what importance we should attach to their data in connection with the question of the relation of the composition of a glacial soil to the age of 
重高

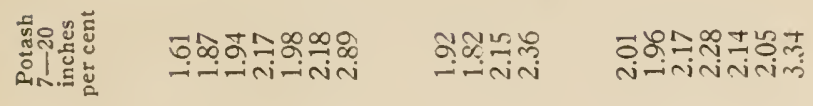
敦

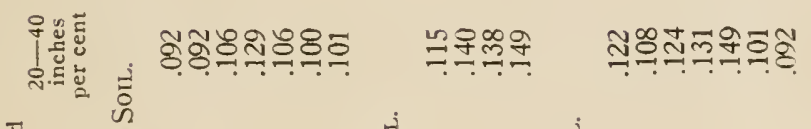

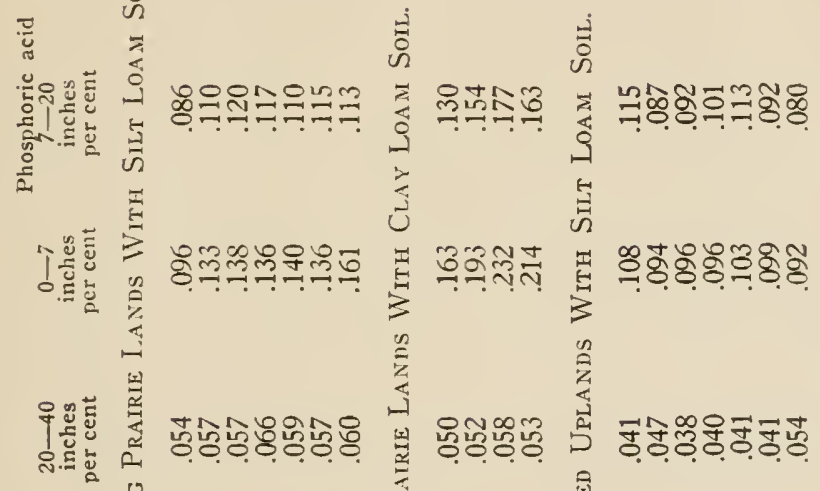

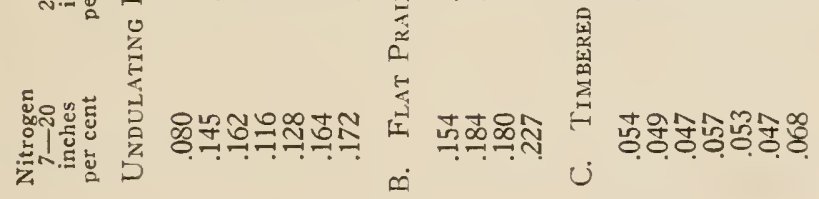

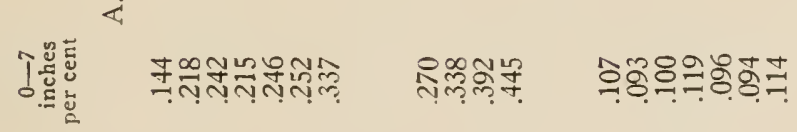

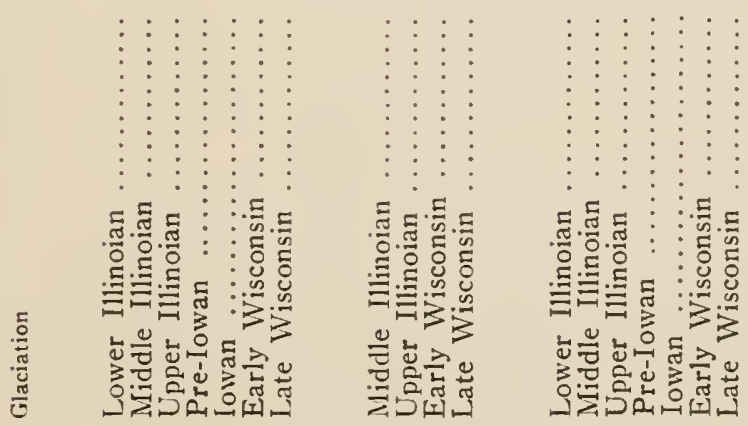


the drift upon which it has been developed. It should be pointed out that Hopkins and Pettit's investigation was not planned to answer this question, but to determine the general character of Illinois soils, their data being reported by glaciations arranged in order of age, in order to bring ont any relation existing between the age and the chemical composition. While they report no physical constants the omission or these is not very serious, as the soils alluded to in table 2 appear to all have been silt loams or clay loams of loessial origin.

The composition does not appear definitely dependent upon the age of the drift except that the Late $W$ isconsin soils are in general richer in potash than those of the earlier formations. This relationship is confined to the prairie soils, there being none within the timbered mplands. Hopkins and Pettit explain this by the assumption that erosion keeps a comparatively fresh and unleached stratum constantly near the surface in the case of the latter.

In a recent study of Jowa soils very similar in conception to that of the Illinois workers, Brown (9) compares Late IVisconsin drift soils with the Kansan drift soils lying just to the east. Following the practice of Iowa geologists, he designates as Iowan the drift sheet which Leverett regards as an integral part of the Kansan. Like Hopkins and Pettit he divides his soil column into three sections, soil $0-62 / 3$ inches, subsurface soil $62 / 3-20$ inches, and subsoil 20-40 inches. He reports neither any physical constants of his samples nor the soil types from which they were taken, most of them probably being taken from unsurveyed counties.

The Late $W$ isconsin soils were collected from three different counties-Clay, Kossuth and Boone--and the Kansas from six different counties-Cerro Gordo, Floyd, Bremer, Blackhawk, Buchanan and Delaware. Thus the most easterly of his Kansas fields were about 200 miles east of his most westerly Late IVisconsin field.

Table 3.-Difference in composition of Iowa soils on Kansan (or Iocian) and Late Wisconsin drifts, as shozem by data of Brozm.

\begin{tabular}{|c|c|c|c|c|c|c|}
\hline \multirow[b]{2}{*}{$\begin{array}{l}\text { Depith } \\
\text { Inches }\end{array}$} & \multicolumn{2}{|c|}{ Nitrogen } & \multicolumn{2}{|c|}{ Phosphoric acid } & \multicolumn{2}{|c|}{ Potatsh } \\
\hline & $\begin{array}{l}\text { Kansan } \\
\text { ner cent }\end{array}$ & $\begin{array}{l}\text { I.ate } W \text { is. } \\
\text { per cent }\end{array}$ & $\begin{array}{l}\text { Kansan } \\
\text { per cent }\end{array}$ & $\begin{array}{l}\text { Late } W \text { is. } \\
\text { per cent }\end{array}$ & $\begin{array}{r}\text { Kansan } \\
\text { per cent }\end{array}$ & $\begin{array}{l}\text { Late Wis. } \\
\text { per cent }\end{array}$ \\
\hline $\begin{array}{l}0-6.6 \\
6.6-20 \\
20-40\end{array}$ & $\begin{array}{l}.226 \\
.142 \\
.056\end{array}$ & $\begin{array}{l}.273 \\
.200 \\
.071\end{array}$ & $\begin{array}{l}.147 \\
.126 \\
.097\end{array}$ & $\begin{array}{l}.160 \\
126 \\
.124\end{array}$ & $\begin{array}{l}1.33 \\
1.44 \\
1.45\end{array}$ & $\begin{array}{l}1.72 \\
1.67 \\
1.55\end{array}$ \\
\hline $\begin{array}{l}\text { Depth } \\
\text { Iuches }\end{array}$ & $\begin{array}{l}\text { Kansan } \\
\text { per cent }\end{array}$ & $\begin{array}{l}\text { Late Wis. } \\
\text { per cent }\end{array}$ & $\begin{array}{l}\text { Carb } \\
\text { Kansan } \\
\text { per cent }\end{array}$ & $\begin{array}{l}\text { Dioxide } \\
\text { Late Wis. } \\
\text { per cent }\end{array}$ & $\begin{array}{c}\text { Freque } \\
\text { Kansan } \\
\text { per cent }\end{array}$ & $\begin{array}{l}\text { of acidity } \\
\text { Late Wis. } \\
\text { per cent }\end{array}$ \\
\hline $\begin{array}{l}0-6.6 \\
6.6-20 \\
20-40\end{array}$ & $\begin{array}{l}0.63 \\
0.63 \\
0.58\end{array}$ & $\begin{array}{l}1.33 \\
1.01 \\
6.02\end{array}$ & $\begin{array}{l}0.018 \\
0.015 \\
0.016\end{array}$ & $\begin{array}{l}0.025 \\
0.035 \\
2.970\end{array}$ & $\begin{array}{l}90 \\
66 \\
70\end{array}$ & $\begin{array}{r}12 \\
0 \\
0\end{array}$ \\
\hline
\end{tabular}

A summary of his data is reported in table 3 . He finds the Late IVisconsin soils much richer in total lime, from 60 to 1100 per cent in all three levels, while the carbonates differ little except in the lowest 
level, in which on the later drift they are abundant. An acid reaction is usually found in all three levels on the Kansan but only rarely on the Late Wisconsin, and then only in the surface section. On the latter drift, the total potash was much higher in the first two sections and slightly higher in the third, while nitrogen was considerably higher in all three levels. In both the first and third sections the total phosphoric acid averaged higher on the Late Misconsin, while the subsurface showed no difference.

McMiller (25) in an investigation of the soils of the most southerly tier of counties in Minnesota, begun in the autumn of 1913 and almost completed before the appearance of the Brown report, conducted a somewhat parallel study. It differed in general conception from the former in that only virgin fields, and these on till plains and terminal moraines, were selected; the sampling was in three one-foot sections, five fields being dealt with in each county. The proportion of gravel and the moisture equivalent are reported for every sample, thus permitting a ready recognition of the general character of the soil and even the identification of the soil type.

Five of the fields sampled by McMiller were on the Kansas, all these being near Spring Valley and on Carrington loam, while 24 were on the Late Wisconsin, four near Albert Lea, five near Wells, five near Fairmont, five near Jackson, five near Worthington and five near Adrian. These 24 fields were distributed among five different types, Carrington loam, Carrington silt loam, Fargo silt loam, Fargo clay loam and Barnes silt loam. When the averages for the five fields near Spring Valley are compared with those for the three un the same soil type near Albert Lea, which constituted the most easterly Late Wisconsin fields, they being about 50 miles to the west, no great differences in properties are shown (Table 4). However, when the averages of all the Late Wisconsin fields are compared with those of the five Kansan the differences are more similar to those reported by Brown.

Table 4-Comparison of Carrington loam at Spring Valley, on the Kansan, with that at Albert Lea, on the Late Wisconsin, from McMiller's data.

\begin{tabular}{|c|c|c|c|c|c|c|}
\hline \multirow[b]{2}{*}{$\begin{array}{l}\text { Depth } \\
\text { Feet }\end{array}$} & \multicolumn{2}{|c|}{ Coarser fragments } & \multicolumn{2}{|c|}{ Moisture equivalent } & \multicolumn{2}{|c|}{ Nitrogen } \\
\hline & $\begin{array}{c}\text { Kansan } \\
\text { per cent }\end{array}$ & $\begin{array}{l}\text { Late Wis. } \\
\text { per cent }\end{array}$ & $\begin{array}{l}\text { Kansan } \\
\text { per cent }\end{array}$ & $\begin{array}{l}\text { Late Wis. } \\
\text { per cent }\end{array}$ & $\begin{array}{c}\text { Kansan } \\
\text { per cent }\end{array}$ & $\begin{array}{l}\text { Late Wis. } \\
\text { per cent }\end{array}$ \\
\hline \multirow{4}{*}{$\begin{array}{l}1 \\
2 \\
3\end{array}$} & 0.47 & 0.00 & 23.8 & 23.1 & .190 & .220 \\
\hline & 1.28 & 0.53 & 19.6 & 21.1 & .076 & .118 \\
\hline & 1.49 & 0.89 & 16.6 & 20.6 & .030 & .063 \\
\hline & \multicolumn{2}{|c|}{ Total phosphoric acid } & \multicolumn{2}{|c|}{ Total potash } & \multicolumn{2}{|c|}{ Carbon dioxide } \\
\hline 1 & .15 & .15 & 1.85 & $1.83^{*}$ & .05 & .05 \\
\hline 2 & .09 & $10^{*}$ & 1.77 & $1.94 *$ & .03 & .05 \\
\hline 3 & .09 & $.15^{*}$ & 1.57 & $1.90^{*}$ & .01 & .05 \\
\hline
\end{tabular}

- Average of four fields, including one on Carrington silt loam. 


\section{FIELD WORK.}

\section{Selection of Fields.}

The three types mentioned above, viz., the Carrington silt loam, an upland prairie type, the Fargo silt loam, a lowland prairie type, and the Carrington loam, a forest type, were selected for study on both drifts.

The fields selected to represent these types on the Kansan are located in the township of Wheeling in the eastern part of the county with the exception of one just over the north line of this (Fig. 3). The fields of Carrington silt loam and Fargo silt loam sampled on the Late Wisconsin are in the townships of Warsaw and Morristown in the southwestern part of the county, while those of Carrington loam on this lrift were selected in the townships of Walcott and Cannon City, none being far distant from the city of Faribault.

The Marshall silt loam, a type developed upon loessial material lerived entirely from pre-Wisconsin drifts and confined to the Kansan side of the dividing line, was studied in addition to the three.just mentioned.

In selecting the individual fields it was the aim to secure those in as nearly their virgin condition as it was possible to obtain them. This is extremely important since, as has recently been pointed out by Glinka (16 p. 96), the formation of soil horizons which are within reach of the plow is not uncommon. Not a single entire field of upland prairie was found. So, in the case of the Carrington silt loam the task of locating suitable tracts from which to take samples was difficult. Practically all the samples taken on this type were from along line fences or heside roadways which it seemed certain had never been plowed. Since they were so easily brought under the plow it is not surprising that entire fields still in an actually virgin condition on this type are no longer to be found. At the time of the field work a few of the original settlers were still living and these were able to give much valuable information. Each field was selected only after the oldest settlers in the neighborhood had been consulted and a more or less complete history of the field had been obtained. Thus in the case of one field, IV, on the Marshall silt loam it was found that an old settler living within half a mile of it had cleared off the brush and plowed the adjacent field in 1858 and had seen it every year since.

In the case of the Fargo silt loam virgin fields were not so difficult to find. On the Kansan, two rather poorly drained meadows, both of which were plowed a few days after the samples were taken, formed two of the fields, the grassy roadsides two others, and a line fence border the fifth, while on the Late Wisconsin all were from line fence borders or beside roadways. 


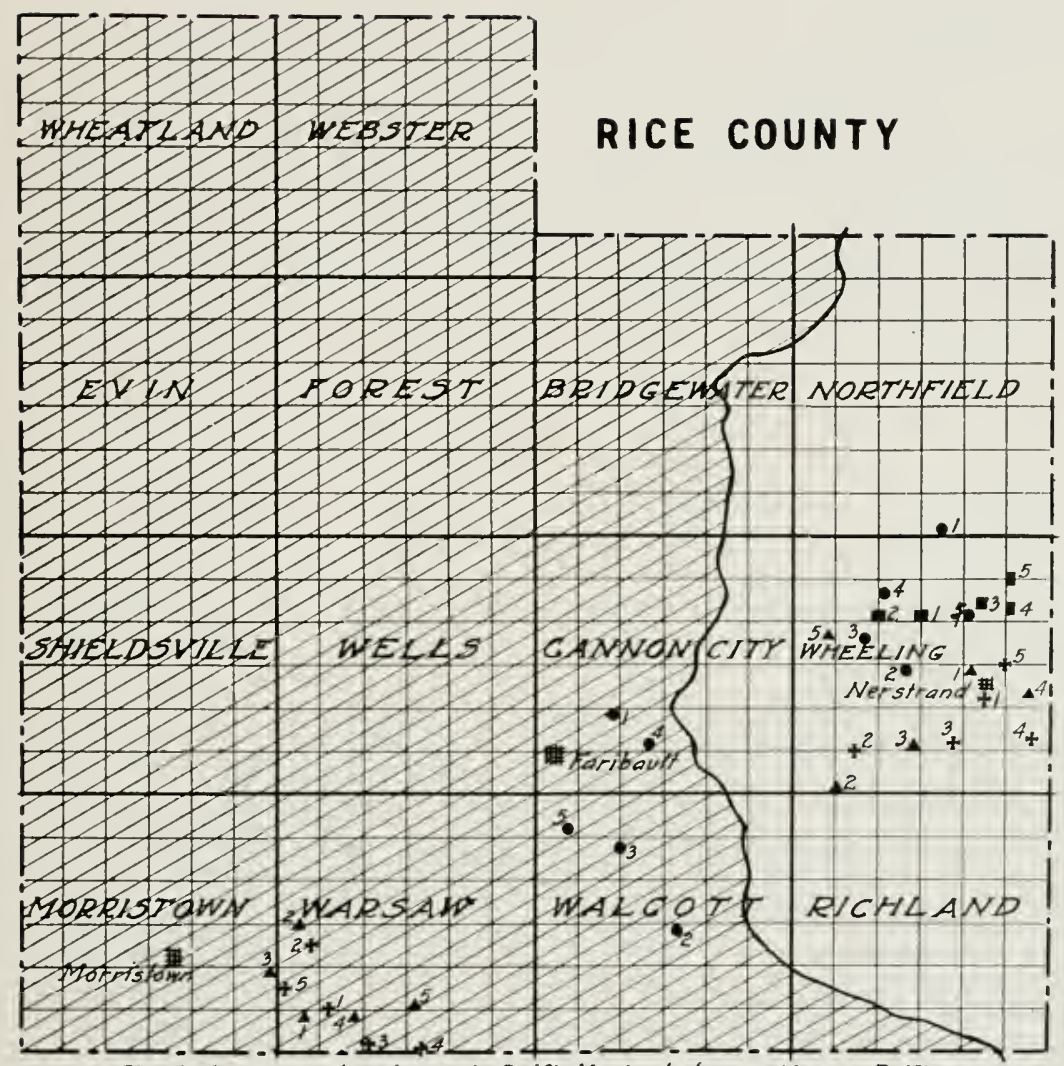

Shaded area; Late Wisconsin Drift. Unshadedarea; Kansan Drint.

- Fields on Carrington Silt Loam

+ Fields on Forgo Silt Loam

- Fields on Carrington Loam

- Fields on Marshall Loam

the fields sampled on each.

Fig. 3.- Nap of Rice County, showing the position of the two drifts and 

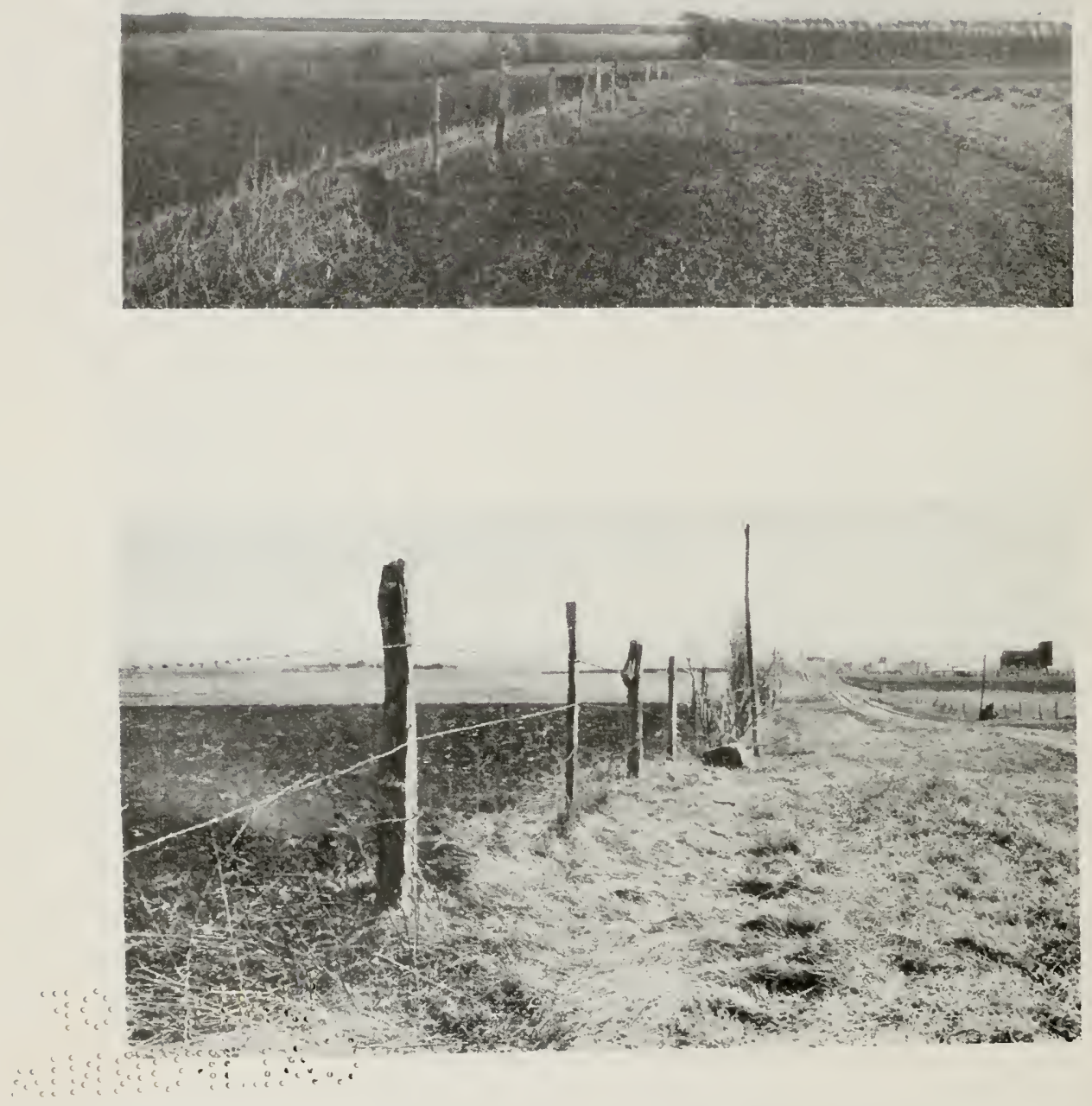

Illustrition OF the Character of the ONly Remaning UNplowed Tracts on the Carrington Shlt Lohi.

1. Fence row on the Kansan, field V.

2. Roadside strip on the Late Wisconsin. field II. 
Satisfactory fields on the Carrington loan were comparatively easy to locate, the required number of properly distributed forested areas being easily found.

On the Marshall silt loam, three of the five ficlds sampled were forested. For the other two, the sets of samples were taken, in one case along a line fence and in the other by the side of a roadway, neither of which, within the recollection of old settlers in the neighborhood, had ever been plowed. Land adjacent to the last two, however, had been cleared of the forest for many years and given over to mixed farming and hence it is probable that they also were originally in forest. These two are designated as "cleared fields."

In the case of each type an effort was made to locate the five fields so that no two would be less than a mile apart and usually this was found possible. On the Marshall silt loan three of the fields were a little less than this distance apart.

\section{Method of Sampling.}

Five fields (Fig. 3) on each of the types chosen on the two drifts were selected and from each one of these two sets of samples were taken, the samples of each set being composites from ten borings made approximately 10 yards apart and to a depth of 3 feet. The surface foot was taken in two 6 -inch sections so that samples from 4 different depths were obtained, viz., 1-6, 7-12, 13-24 and 25-36 inches. Two augers, one 2.0 and the other 1.5 inches in diameter, were used in the work, the larger being employed to take the surface section and to enlarge the hole preparatory to taking the lower sections with the smaller. Care was taken to prevent the samples from the lower sections becoming contaminated with the soil from the upper part of the hole as the auger was withdrawn. The composites of ten borings are designated "Set 1 samples" and "Set 2 samples," while the composites made up in turn from these, and so representing twenty borings, are referred to as the "field samples." "The so-called "drift samples" for each type were secured by combining equal weights of the "field samples," and so are composites from 100 borings scattered over a considerable territory. 


\section{EXPERIMENTAL.}

\section{A. Relative Fineness of Texture.}

When taking samples the fragments larger than $21 n m$. in diameter that were brought up by the auger were included in the sample. In cases where a pebble an inch in diameter or larger obstructed the way a new boring was made. No attempt was made to ascertain the amount of coarse gravel or of rock fragments of still larger size. On glaciated areas such as these this would vary considerably from place to place and its determination would involve the handling of large amounts of soil and subssil in the field.

\section{Froportion of Coarser Fragments.}

The ,ercentage of the coarser material, as above defined, and the average reight of the fragments (Tables 5 to 12 ) were determined in all the field samples. These data also serve as a rough index of the varying amounts of coarse gravel and boulders present in the different sections and on the two drifts.

Carrington Silt Loam. On the Kansan (Table 5) the average percentages found for the three foot section in the different fields are very similar, while the differences between the amounts found in the corresponding sections are small, the maximum being found, as would be expected, in the third foot-section. The average for all sections of the 5 fields is 0.51 per cent.

Table 5--Coarse graiel in the different sections from the five fields on Carrington silt loam.

\begin{tabular}{|c|c|c|c|c|c|c|}
\hline $\begin{array}{l}\text { Depth } \\
\text { Inches }\end{array}$ & $\begin{array}{l}\text { Field } \\
\text { I } \\
\text { per cent }\end{array}$ & $\begin{array}{l}\text { Field } \\
\text { II } \\
\text { per cent }\end{array}$ & $\begin{array}{l}\text { Field } \\
\text { III } \\
\text { per cent }\end{array}$ & $\begin{array}{l}\text { Field } \\
\text { IV } \\
\text { per cent }\end{array}$ & $\underset{\text { Vield }}{\text { Fer cent }}$ & $\begin{array}{c}\text { Average fo } \\
5 \text { fields } \\
\text { per cent }\end{array}$ \\
\hline & & & - KANSAN. & & & \\
\hline $1-6$ & 0.06 & 0.52 & 0.23 & 0.15 & 0.12 & 0.22 \\
\hline $7-12$ & 0.04 & 0.68 & 0.33 & 0.21 & 0.50 & 0.35 \\
\hline $13-24$ & 0.13 & 0.37 & 0.31 & 0.13 & 0.14 & 0.22 \\
\hline $25-36$ & 1.08 & 0.77 & 1.15 & 1.06 & 1.15 & 1.04 \\
\hline $\begin{array}{l}\text { Average } \\
1-36^{*}\end{array}$ & 0.42 & 0.58 & 0.55 & 0.46 & 0.53 & 0.51 \\
\hline
\end{tabular}

2. Late Wisconsin.

$\begin{array}{ccccccc}1-6 & 0.17 & 1.18 & 1.00 & 1.03 & 0.99 & 0.88 \\ 7-12 & 0.51 & 1.08 & 1.25 & 1.38 & 0.98 & 1.04 \\ 13-24 & 1.32 & 0.91 & 2.83 & 1.91 & 2.38 & 1.87 \\ 25-36 & 1.94 & 2.85 & 3.44 & 2.59 & 4.32 & 3.03 \\ \text { Average } & & & & & & \\ 1-36 & 1.20 & 1.63 & 2.46 & 1.90 & 2.56 & 1.95\end{array}$

*To secure the averages for the 3 foot-sections the percentages from the two 6-inch sections were averaged and this result, in turn averaged with the percentages for the two lower sections, This procedure was followed for all tables reported hereafter. 
The percentages found for the Late 11 inconsin are, on the average, 280 per cent higher than those for the Kansan. It is evident from this that the processes of weathering are the more advanced on the older deposit. An examination of the particles shows that shales, linestones, and cherty rocks are much more abundant on the younger formation, having practically disappeared from the older.

For this type the average weight (Table 6) of the gravel particles brought up by the auger is very uniform, showing little variation from field to field or from arift to drift.

Table 6.-Arerage weight of coarse graicl particles in the different settions trom the fice fields on Carrington silt loam.

\begin{tabular}{|c|c|c|c|c|c|c|}
\hline $\begin{array}{l}\text { Depth } \\
\text { Inches }\end{array}$ & $\begin{array}{c}\text { Field } \\
\text { I } \\
\text { grams }\end{array}$ & $\begin{array}{c}\text { Field } \\
\text { Il } \\
\text { grams }\end{array}$ & $\begin{array}{c}\text { Field } \\
\text { III } \\
\text { grams }\end{array}$ & $\begin{array}{l}\text { Fielul } \\
\text { IV } \\
\text { grams }\end{array}$ & $\begin{array}{c}\text { Field } \\
\text { grams }\end{array}$ & $\begin{array}{l}\text { Average for } \\
5 \text { fields } \\
\text { grams }\end{array}$ \\
\hline \multicolumn{7}{|c|}{ 1. KANSAN. } \\
\hline $1-6$ & .022 & .022 & .043 & .020 & .018 & .025 \\
\hline $7-12$ & .019 & .031 & .043 & .020 & .064 & .035 \\
\hline $13-24$ & .017 & .020 & .031 & .016 & .023 & .021 \\
\hline $\begin{array}{l}25-36 \\
\text { Average }\end{array}$ & .043 & .021 & .044 & .024 & .032 & .033 \\
\hline $1-36$ & .027 & .022 & .039 & .020 & .0 .32 & .028 \\
\hline
\end{tabular}

2. Late Wiscoxis.

$\begin{array}{ll}1-6 & .020 \\ 7-12 & .018 \\ 13-24 & .024 \\ 25-36 & .020 \\ \text { Average } \\ 1-36\end{array}$

$\begin{array}{ll}.037 & .02 \\ .024 & .03 \\ .027 & .02 \\ .027 & .02 \\ .028 & .02\end{array}$

$\begin{array}{lll}.020 & .065 & .039 \\ .031 & .027 & .026 \\ .028 & .031 & .024 \\ .022 & .027 & .024\end{array}$

$.026 \quad .035 \quad .027$

Fargo Silt Loam. The general distribution (Table 7 ) of coarser fragments is much the same as on the Carrington silt loam, the maximum being in the third foot and on the average only 25 per cent as much on the Kansan as on the later formation. On the former, three fields, I, III and $Y$. show little or no coarse gravel in the surface foot, while only one. II, show's as much as 1.0 per cent in the lowest section. On the Late Wisconsin the range is from 0.23 per cent to 4.38 per cent, with an average of 1.50 per cent for the three font section on the five fields.

The average weights for the gravel particles (Table 8 ) are quite similar both from field to field and on the two drifts. The second footsection from Field III on the Kansan shows the highest average of all the field samples, but this was due to the inclusion of several stones larger than those one is ordinarily able to bring up with the auger. 
Table 7.-Coarse gratel in the different sections from the five fields on Fargo silt loam.

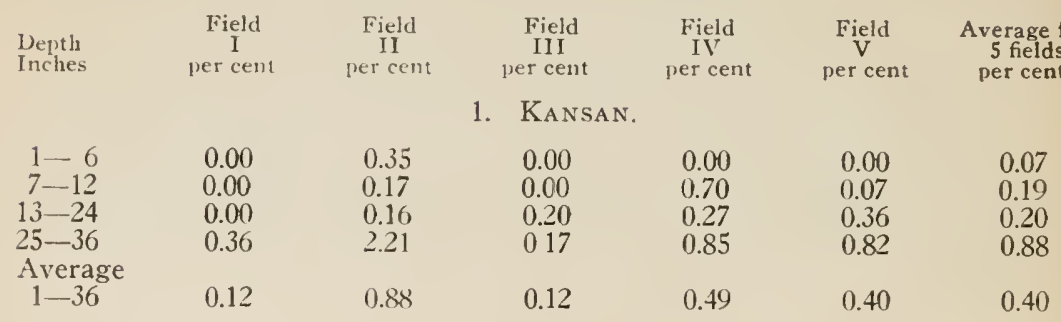

2. Late Wisconsin.

$\begin{array}{lllllll}1-6 & 0.67 & 0.23 & 0.64 & 0.58 & 0.46 & 0.52 \\ 7-12 & 1.00 & 0.23 & 1.06 & 1.44 & 0.83 & 0.91 \\ 13-24 & 0.94 & 0.79 & 1.51 & 4.28 & 0.68 & 1.64 \\ 25-36 & 1.65 & 1.06 & 2.07 & 4.38 & 1.57 & 2.15 \\ \text { Average } & & & & & & \\ 1-36 & 1.14 & 0.69 & 1.43 & 3.22 & 0.96 & 1.50\end{array}$

Table 8.-Avcrage weight of coarse grazel particles in the different sections on Fargo silt loam.

$\begin{array}{lcccccc}\begin{array}{l}\text { Depth } \\ \text { Inches }\end{array} & \begin{array}{c}\text { Field } \\ \text { I } \\ \text { grams }\end{array} & \begin{array}{c}\text { Field } \\ \text { II } \\ \text { grams }\end{array} & \begin{array}{c}\text { Field } \\ \text { III } \\ \text { grams } \\ \text { 1. } \begin{array}{c}\text { KaINSAN. } \\ 1-6\end{array}\end{array} & \begin{array}{c}\text { Field } \\ \text { IV } \\ \text { grams }\end{array} & \begin{array}{c}\text { Field } \\ \text { V } \\ \text { grams }\end{array} & \begin{array}{c}\text { Average for } \\ 5 \text { fields } \\ \text { grams }\end{array} \\ 7-12 & .000 & .011 & .000 & .000 & .000 & .002 \\ 13-24 & .000 & .020 & .011 & .049 & .017 & .019 \\ 25-36 & .000 & .017 & .193 & .030 & .024 & .053 \\ \begin{array}{c}\text { Average } \\ 1-36\end{array} & .046 & .029 & .028 & .081 & .044 & .046 \\ & .015 & .020 & .075 & .045 & .025 & .036\end{array}$

$\begin{array}{ccccccc}1-6 & .025 & .027 & .023 & .020 & .014 & .022 \\ 7-12 & .025 & .019 & .014 & .022 & .018 & .020 \\ 13-24 & .023 & .025 & .017 & .051 & .015 & .026 \\ 25-36 & .030 & .020 & .018 & .025 & .020 & .023 \\ \text { Average } & .026 & .023 & .018 & .032 & .017 & .023 \\ 1-36 & .023\end{array}$

Carrington Loum. On both drifts (Table 9) the variation from field to field is much greater than with the two other types. Here also in general the maximum is found in the third foot. The average for the five fields is somewhat the higher on the Kansan, the opposite of what was found for the two other types. This is caused by the exceptionally high percentages for the third foot of Fields I, II and III on the older drift. The topography of this type, as mentioned above (p. 12) is the most rolling of any sampled and accordingly the soil is the most apt to be strongly eroded, hence it is not unlikely that much of the material originally at the surface on these three fieids has been carried away, thus bringing less weathered layers within the three foot section. 
Table 9.-Coarse gruiel in the different sictions from the fire fields on Carrington loam.

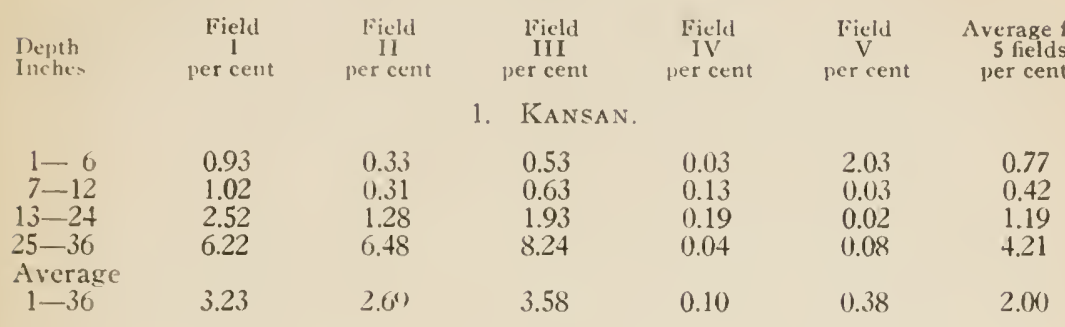

2. Late Wiscunsin.

\begin{tabular}{|c|c|c|c|c|c|c|}
\hline $1-0$ & 0.47 & $1.0 \pi$ & 0.64 & 1.79 & 0.46 & 0.89 \\
\hline $7-12$ & 0.94 & 0.75 & 0.27 & 1.65 & 0.26 & 0.77 \\
\hline $13-24$ & 1.52 & 1.70 & 1.10 & 4.25 & 0.18 & 1.75 \\
\hline $25-36$ & 1.81 & 2.93 & 2.90 & 4.92 & 1.98 & 2.91 \\
\hline $\begin{array}{c}\text { Average } \\
1-36\end{array}$ & 1.34 & 1.8 & 1.48 & 363 & 0.94 & 1.83 \\
\hline
\end{tabular}

An examination of the minerals in the third foot-section on the two drifts showed that on the Kansan considerably larger quantities of trap) rocks and iron minerals (limonite, magnetite, etc.) were present than on the Late Wisconsin, while on the latter a higher percentage of quartz, light colored quartzite, chert and shales was observerl, 110 trace of the two last named rocks being found on the Kansan.

The average weight of the gravel particles (Table 10) in the three foot section is very similar for all fields on the Late Wisconsin and for Fields IV and $V$ on the Kansan. The average weight for the other fields, I, II and III, on the latter, is slightly higher, lue to the heavier particles found in the third foot-section.

Table Ic.-Aicrage weight of coarse graicl particles in the different sections from the fin'e ficlds on Carrington loan.

\begin{tabular}{|c|c|c|c|c|c|c|}
\hline $\begin{array}{l}\text { Deputh } \\
\text { Inches }\end{array}$ & $\begin{array}{c}\text { Field } \\
1 \\
\text { grams }\end{array}$ & $\begin{array}{l}\text { Field } \\
\text { II } \\
\text { granıs }\end{array}$ & $\begin{array}{l}\text { Field } \\
\text { III } \\
\text { grams }\end{array}$ & $\begin{array}{c}\text { Field } \\
\text { IV } \\
\text { grams }\end{array}$ & $\begin{array}{c}\text { Field } \\
\text { V } \\
\text { grams }\end{array}$ & $\begin{array}{c}\text { Average fo } \\
5 \text { fields } \\
\text { grams }\end{array}$ \\
\hline \multicolumn{7}{|c|}{ 1. Kansan. } \\
\hline $1-6$ & .020 & .026 & .020 & .009 & .035 & .022 \\
\hline $7-12$ & .020 & .024 & .026 & 035 & .014 & .024 \\
\hline $13-24$ & .033 & .033 & .038 & (1)37 & .017 & .032 \\
\hline $25-36$ & .043 & .039 & .050 & .016 & .027 & .035 \\
\hline $\begin{array}{l}\text { Average } \\
1-36\end{array}$ & .032 & .032 & .037 & .025 & .023 & .030 \\
\hline \multicolumn{7}{|c|}{ 2. IATE Wisconsin. } \\
\hline $1-6$ & .019 & .031 & .035 & .026 & .036 & .029 \\
\hline $7-12$ & .021 & .025 & .020 & .021 & .015 & .020 \\
\hline $13-24$ & .021 & .030 & .023 & .033 & .017 & .025 \\
\hline $25-36$ & .021 & .030 & .033 & .030 & .025 & .028 \\
\hline $\begin{array}{c}\text { Average } \\
1-36\end{array}$ & .021 & .029 & .028 & .029 & .022 & .026 \\
\hline
\end{tabular}


Marshall Sill Loan. This type has developed on a loessial formation and accordingly it would not be expected to carry many, if any, fragments coarser than $2 \mathrm{~mm}$. The thickness of the deposit might have an influence on the number of these since, in case it were shallow, burrowing animals and insects might carry upward a sufficient amount of the underlying till to modify to a certain degree the mechanical, if not the chemical composition of the soil (21, p. 90-91).

Un one field, I (Table 11) and in the first set from another, III, the till was encountered in the third foot-section. Set 2 of the latter field being evidently entirely on the till, since it carried as high a percentage of coarse fragments as any field on the Carrington loam. The amounts found in the two sets on this field are given below:

$\begin{array}{ccc}\text { Depth } & \text { Set 1 } & \text { Set } 2 \\ \text { Inches } & \text { percent } & \text { per cent } \\ 1-6 & .14 & 2.25 \\ 7-12 & .14 & .51 \\ 13-24 & .13 & 3.50 \\ 25-36 & 3.99 & 10.17\end{array}$

The large area of this kind of soil west of Nerstrand, upon whicil Fields I and III are located has a very shallow deposit of loess (11. p. 36.), while that to the north and east, upon which sites for Fields II, IV and $V$ were selected, appears to have a greater thickness and accordingly is more representative of this type. Few fragments were found in the samples from the three fields last mentionerl.

Table II.-Coarsi gratel in the different sections from the five fields on larshall silt loam.

Dejuth

Inclies

Field
I
jer cent

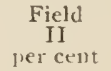

Field
III

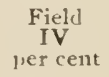

Field
jer cent

Average for
5 fields

1. KANSAN

$\begin{array}{ll}1-6 & 0.00 \\ 7-12 & 002 \\ 13-24 & 0.48 \\ 25-36 & 1.92 \\ \text { Average } & \\ 1-36 & 0.81\end{array}$

0.05
0.02
0.00
0.05
0.0 .3

1.19

0.32

1.81

7.08

3.21

0.00
0.02
0.01
0.00
0.01

0.00

0.00

0.00

0.00

0.24

0.07

0.46

1.81

0.81

Table 12.- Aicrage weisht of coarse sratel parliclis in the different sections from the fia'e ficlds on Marshall silt loam.

\begin{tabular}{|c|c|c|c|c|c|c|}
\hline $\begin{array}{l}\text { Depth } \\
\text { Inclies }\end{array}$ & $\begin{array}{c}\text { Field } \\
\text { I } \\
\text { grams }\end{array}$ & $\begin{array}{l}\text { Field } \\
\text { II } \\
\text { grams }\end{array}$ & $\begin{array}{c}\text { Field } \\
\text { III } \\
\text { grams }\end{array}$ & $\begin{array}{c}\text { Fielt } \\
\text { IV } \\
\text { granss }\end{array}$ & $\begin{array}{l}\text { Field } \\
\text { grams }\end{array}$ & $\begin{array}{l}\text { Average for } \\
5 \text { fields } \\
\text { grams }\end{array}$ \\
\hline \multicolumn{7}{|c|}{ 1. KANSAN. } \\
\hline $1-6$ & .011 & .025 & .024 & .000 & .000 & .012 \\
\hline $7-12$ & .011 & .013 & .018 & .005 & .000 & .009 \\
\hline $13-24$ & .030 & .000 & .040 & .005 & .000 & .015 \\
\hline $25-36$ & .032 & .049 & .029 & .1000 & .000 & .022 \\
\hline $\begin{array}{l}\text { dverage } \\
1-36\end{array}$ & .024 & .023 & .030 & .003 & .000 & .016 \\
\hline
\end{tabular}


Discussion. The atrerage percentages of coarser fragments (Table 13) are higher in the soils on the Kansan than in those of the Late IVisconsin, with exception of the third foot-section of the Carrington loam. The explanation of this exception appears to lie in the fact that on three fields erosion has removed the surface material and thus left the lessweather portion nearer to the surface than it is ordinarily found. The larger amount of coarser particles on the younger formation may be due partially to a less advanced degree of weathering than on the older drift. This also accounts for the clifferent amounts of softer rock: (limestones, shales and cherty material) found on the two drifts. these on the older formation having practically entirely given way to the processes of weathering to a depth greater than three feet.

Glacial material was encountered in the third foot on two fields of Marshall silt loanı, but on the other three the thickness of the loess deposit was sufficient to be characteristic.

Table 13.-Coarse gravel in the different sections. The data are the vierages for the fire fields on each type reported in the last column of tables 5, 7 , o and $I I$.

\begin{tabular}{|c|c|c|c|c|c|c|c|}
\hline \multirow[b]{2}{*}{$\begin{array}{l}\text { Depth } \\
\text { Inches }\end{array}$} & \multicolumn{2}{|c|}{ Carrington silt loan! } & \multicolumn{2}{|c|}{ Fargo silt loam } & \multicolumn{2}{|c|}{ Carrington loam } & \multirow{2}{*}{$\begin{array}{l}\text { Marshall silt } \\
\text { loam } \\
\text { percent }\end{array}$} \\
\hline & $\begin{array}{l}\text { Kansan } \\
\text { per cent }\end{array}$ & $\begin{array}{l}\text { Late } 1 \mathrm{is} \text {. } \\
\text { per cent }\end{array}$ & $\begin{array}{l}\text { Kansan } \\
\text { yer cent }\end{array}$ & $\begin{array}{l}\text { Late Wis. } \\
\text { per cent }\end{array}$ & $\begin{array}{l}\text { Kansan } \\
\text { per cent }\end{array}$ & $\begin{array}{l}\text { Late Wis. } \\
\text { per cent }\end{array}$ & \\
\hline $1-0$ & 0.22 & 0.88 & $0.0 \mathrm{~T}$ & 0.52 & $0.7 \pi$ & 0.89 & 0.24 \\
\hline $7-12$ & 0.35 & 1.04 & 0.19 & 0.91 & 0.42 & 0.77 & 0.07 \\
\hline $13-24$ & 0.22 & 1.87 & 0.20 & 1.64 & 1.19 & 1.75 & 0.46 \\
\hline $25-36$ & 1.04 & 3.03 & 0.88 & 2.15 & +.21 & 2.91 & 1.81 \\
\hline $\begin{array}{c}\text { Average } \\
1-36\end{array}$ & 0.51 & 1.95 & 0. 40 & 1.50 & 2.00 & 1.83 & 0.81 \\
\hline
\end{tabular}

The average weight of the gravel particles (Table 14) found in the three-foot section was much the same from type to type and from drift to drift, that of those fomd on the Kansan being slightly higher than that of those on the Late Wisconsin, the difference being greatest on the Fargo silt loam.

Table I7.-Aierage aight of course graicl particles in the different sections. The data are the acerages for the fice fields on each type reported in the last column of tables 6,8, ro and 12 .

\begin{tabular}{|c|c|c|c|c|c|c|c|}
\hline \multirow[b]{2}{*}{$\begin{array}{l}\text { Wepth } \\
\text { Inches }\end{array}$} & \multicolumn{2}{|c|}{ Carrington silt loam } & \multicolumn{2}{|c|}{ Fargo silt loan } & \multicolumn{2}{|c|}{ Carrington loam } & \multirow{2}{*}{$\begin{array}{l}\text { Marshall silt } \\
\text { loam } \\
\text { grams }\end{array}$} \\
\hline & $\begin{array}{c}\text { Kansan } \\
\text { grams }\end{array}$ & $\begin{array}{c}\text { 1.ate Wis. } \\
\text { grams }\end{array}$ & $\begin{array}{l}\text { Kansan } \\
\text { grams }\end{array}$ & $\begin{array}{c}\text { Late Wis. } \\
\text { grams }\end{array}$ & $\underset{\text { gramsan }}{\text { Kansan }}$ & $\begin{array}{l}\text { Late Wis. } \\
\text { grams }\end{array}$ & \\
\hline $1-6$ & .025 & .039 & .002 & .022 & .022 & .029 & .012 \\
\hline $7-12$ & .035 & .026 & .019 & .020 & .024 & .020 & .009 \\
\hline $13-24$ & .021 & .024 & .053 & .026 & .032 & .025 & .015 \\
\hline $25-36$ & .033 & .024 & .046 & .023 & .035 & .028 & .022 \\
\hline $\begin{array}{l}\text { Average } \\
1-36\end{array}$ & .028 &.$(1) 27$ & .036 & .023 & .030 & .026 & 016 \\
\hline
\end{tabular}




\section{Texture of Fine-earth.}

As the most satisfactory method of ascertaining the similarity in texture of the fine-earth of the samples used in this study the determination of the moisture equivalent ( 7 ) was selected. The relation of this to the mechanical composition and other physical constants has been discussed by various atuthors as mentioned above.

The moisture equivalents of the samples in the two sets from each field were determined (Tables 15 to 18 ). The data in Table 15. the first part of table 16 and those for Field $I$ in the first part of table 17 , are the means of duplicate determinations, the others being derived from single determinations. The concordance of duplicate determinattions may be illustrated by the results from the 136 samples mentioned, only two showing a difference greater than 11nity. Another illustration is afforded by the data in table 19.

Carrington Silt Loam. On the Kansan Drift this type showed (Table 15) very little variation from set to set within the same field and but a slightly greater one from field to field, the latter being the most marked in the two sections from the surface foot where there was also the greatest variation in the percentage of organic matter (6, p. 18). The highest value, 33.5 , was found in the surface section, and the lowest, 22.1, in the third foot.

On the Late Wisconsin the variation from field to field was no greater than on the Kansan. but in Field III the first set averaged only 20.5 and the second 26.7, compared with 34.8 for Set 2 from Field $\dot{I}$. The latter field differs markedly from the four others on this drift and shows the highest value of all the fields sampled on this type, those for the four sections ranging only from 33.3 to 35.3 . The averages for the five fields on the two llifts are very similar.

Fargo Silt Loam. (On the Kansan (Table 16) this type shows little variation either within the sane field or from field to field. but on the Late Wisconsin there is a somewhat wider variation in both. The range is from 23.1, found in the subsoil to $52.5 \mathrm{in}$ the surface. The averages for the surface 6 -inch sections on the two drifts show a marked difference, that for the Kansan being 45.9 compared with 35.9 on the other. This, in all probability, is due to the larger amount of orsanic material in the former $(6, \mathrm{p}, 18)$ as indicated by the percentages of organic carbon (Table 53), nitrogen (Table 57) and volatile matter (Table 52). On the Kansan the organic carbon rises to 9.47 per cent comparer with 5.71 on the Late Wisconsin. 


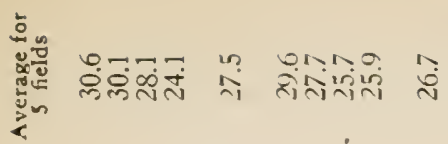

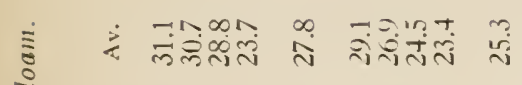

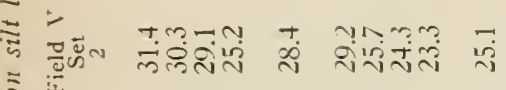

5

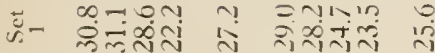

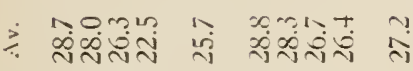

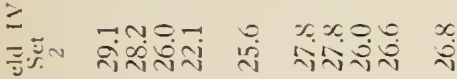

- tomo a monira 1

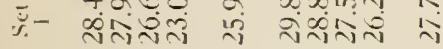

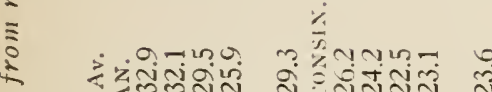

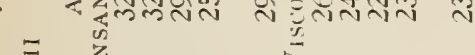

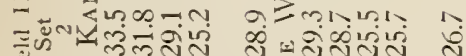

एँ

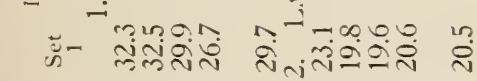

亏

ปั

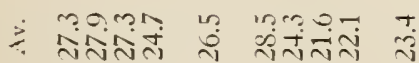

$3=$

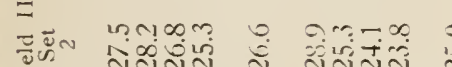

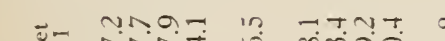

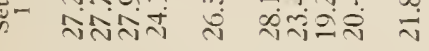

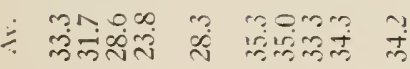

$-$

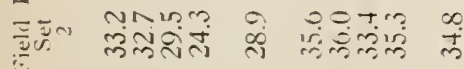

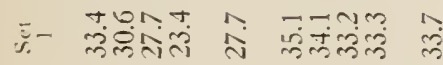

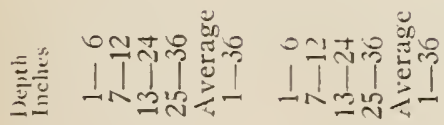

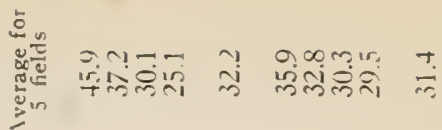

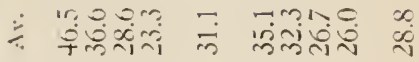

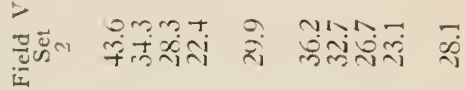

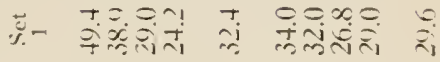

- rionir

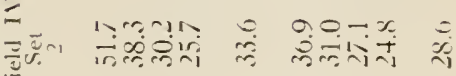

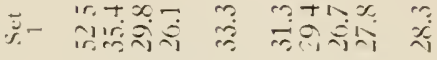

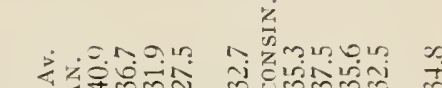
=

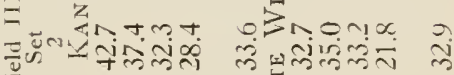
ए.

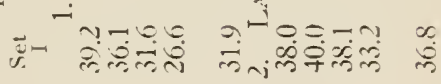

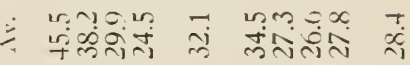

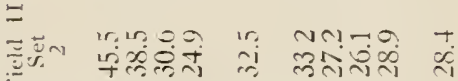

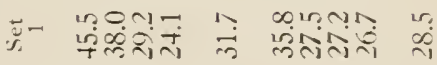

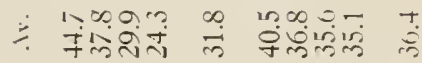

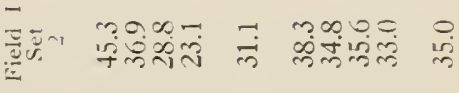

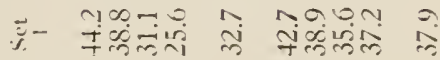

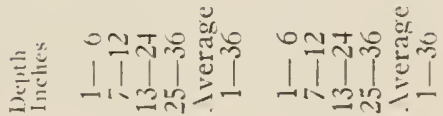




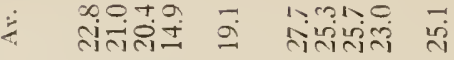

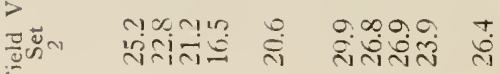

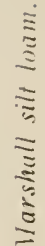

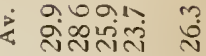

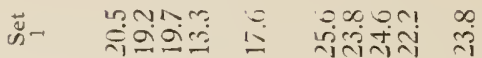

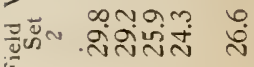

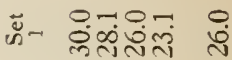

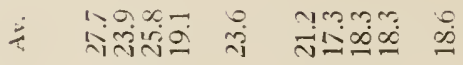

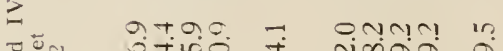

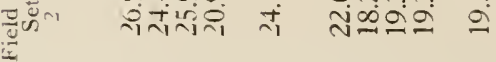

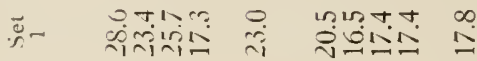

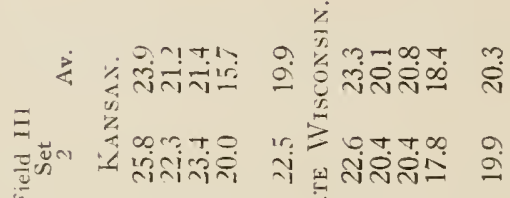

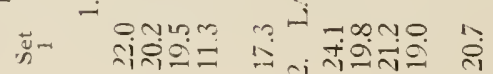

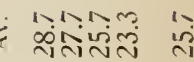

¿ inciar o

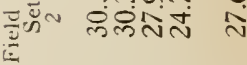

i. जiniñ

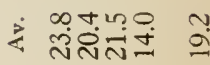

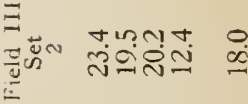

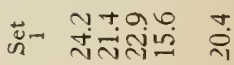

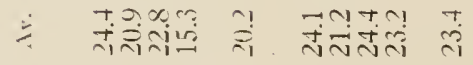

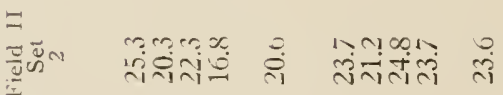

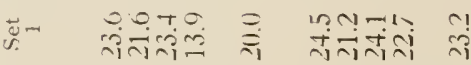

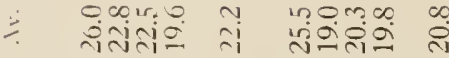

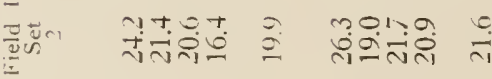

戶.

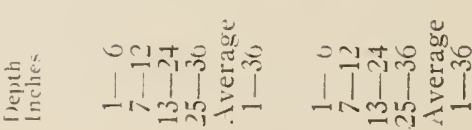

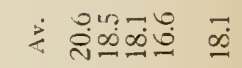

$=$

चัँ

घั-

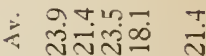

चัँ

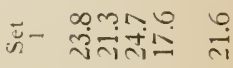

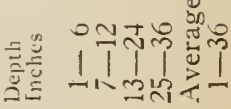


Carrington 1.um. There is considerable variation in texture within the individual fickls and from field to field (Table 17) on the Kansan, this being more pronounced in the third foot. suggesting that at this depth, disintegration has not proceeded as far on the younger Irift. On the Late Misconsin, the variation within the same field and irom field to field is not so wreat. Burke and Kolbe (11, p. 22), in lescribing this type. state that "the texture of the surface soil is for the most part uniform, but the color and denth are variable. Areas of minimum depth apparently have resulted from erosion, those of maximum depth representing more probably the natural conditions.'

It is to be observed that the moisture expuivalent is in most cases licher for the second foot-section than for the 6 -inch section above this. The organic matter in forest soils, such as the Carrington loam, is low even in the surface six inches and a lack of this, compled with the translocation of clas particles (lownwarel into the second foot may account for this rather regular variation. The averages range from 24.8 in the surface section to 16.9 in the subsoil.

Marshall Silt Loam. (In this type (Table 18) considerable variation within Fields II and II is slown and especially great differences between Set 1 from Ficld II and Set 2 from Field IV the former averaging 16.3 and the latter 27.6 , or nearly 70 per cent higher. To eliminate any chance of differences in speed of the centrifuge, etc., causing this, the corresponding samples from these two fields were run side by side (Table 19). It will be seen that these awree very closely with the

Table 19.--Moisture e'quivalents of samples from two ficlds of Marshall silt loam.

$$
\begin{gathered}
\begin{array}{c}
\text { Depth } \\
\text { Inches }
\end{array} \\
1-6 \\
7-12 \\
1.3-24 \\
25-36
\end{gathered}
$$

Det.
I
18.5
16.0
15.9
15.7

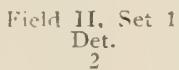

17.8

16.5

15.5

15.1
Av.

18.2

16.3

15.7

15.4

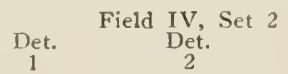

30.4

30.4

27.9

25.5
Av.

30.3 30.2 28.0 25.3

first determinations, so sreat a variation either within the same field or between the different fields on this type was not anticipated. From its loessial origin, a texture more uniform than that on a type developed on the till was to have been expected. In Fields IV and V the moisture equivalents for the different sections are distinctly higher than in the three other fields. The area in which the former two are located while originally on the very fringe of the forest has, for many years, been clear even of brush and the fields on both sides of these "fence row" fields have been kept under mixed farming conditions, which has permitted an accumulation of organic matter somewhat similar to that which would accrue under prairie conditions. While this might account for the greater moisture holding capacity in the surface foot it could not explain the variation in the lower sections. 
Discussion. 'The averages for the five fields on the different types (Table 20) show little variation from drift to drift. On the Kansan the Fargo silt loam appears to have a finer texture in the two upper sections than in the corresponding ones on the Late $W$ isconsin, but this is probably due to the higher content of organic matter on the former.

Table 20.-Hoisture equitalents of samples from the different types on the two drifts. The data are arerages for the fire fields reported in tables 15 to 18 inclusive.

\begin{tabular}{|c|c|c|c|c|c|c|c|}
\hline $\begin{array}{l}\text { Depth } \\
\text { Inches }\end{array}$ & $\begin{array}{l}\text { Carringtc } \\
\text { Kansan }\end{array}$ & $\begin{array}{l}\text { silt loam } \\
\text { Late Wis. }\end{array}$ & $\underset{\text { Kansan }}{\text { Fargo }}$ & $\begin{array}{l}\text { ilt loam } \\
\text { Late Wis. }\end{array}$ & $\underset{\text { Kansan }}{\text { Carrir }}$ & $\begin{array}{l}\text { ton loam } \\
\text { Late Wis. }\end{array}$ & $\underset{\text { Marshall silt }}{\text { Marm }}$ \\
\hline $\begin{array}{r}1-6 \\
7-12 \\
13-24 \\
25-36\end{array}$ & $\begin{array}{l}30.6 \\
30.1 \\
28.1 \\
24.1\end{array}$ & $\begin{array}{l}29.6 \\
27.7 \\
25.7 \\
25.9\end{array}$ & $\begin{array}{l}45.9 \\
37.2 \\
30.1 \\
25.1\end{array}$ & $\begin{array}{l}35.9 \\
32.8 \\
30.3 \\
29.5\end{array}$ & $\begin{array}{l}24.8 \\
22.0 \\
22.6 \\
16.9\end{array}$ & $\begin{array}{l}24.4 \\
20.6 \\
21.9 \\
20.5\end{array}$ & $\begin{array}{l}25.4 \\
23.3 \\
22.9 \\
19.1\end{array}$ \\
\hline $\begin{array}{c}\text { Average } \\
1-36\end{array}$ & 27.5 & 26.7 & 32.2 & 31.4 & 21.0 & 21.6 & 22.1 \\
\hline
\end{tabular}

The Carrington loam shows a more pronounced variation in texture from drift to drift than is found with the other types, this being greatest in the third foot-section. However, the averages for the five fields on the two drifts are very similar.

To obtain the true moisture equivalent a correction for the coarse gravel would need to be made, but this does not affect the actual waterholding capacity, since the rock fragments neither increase or decrease the amount of water held by the fine-earth.

The uniformity in texture on the same type on both drifts shows that the U. S. Bureau of Soils Surveyors were fully justified in their classification. Other differences are not so apparent in the field and are brought out only by a laboratory investigation.

The moisture equivalents, computed from the mechanical analysis (Table 1 ) by formulas proposed by Briggs and Shantz ( 8, p. 73 ) and Alway and Russel (5, p. 842) do not agree satisfactorily with those obtained by direct determination, although the values found by the Alway and Russel formula for the two cleared fields on the Marshall silt loam resemble very closely those found by direct determination. This is to be expected, since this formula was developed for loessial soils only, and it was pointed out $(5, \mathrm{p} .843)$ that different formulas would be required for various soil types. The most marked difference between the computed and actual values is found with the surface soil on the Fargo silt loam, where the former are much too low. 


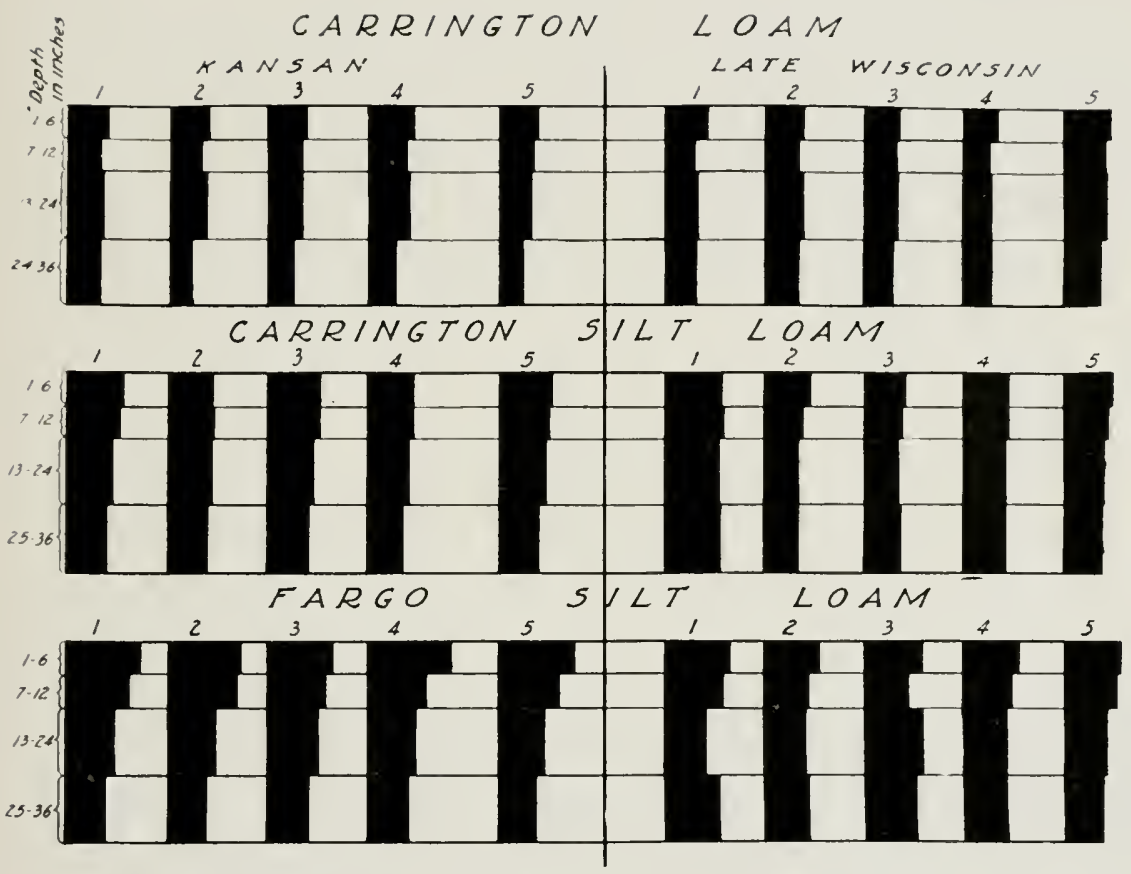

Fig. 4.-Diagram showing the mean moisture equivalents of the different types on both drifts. 

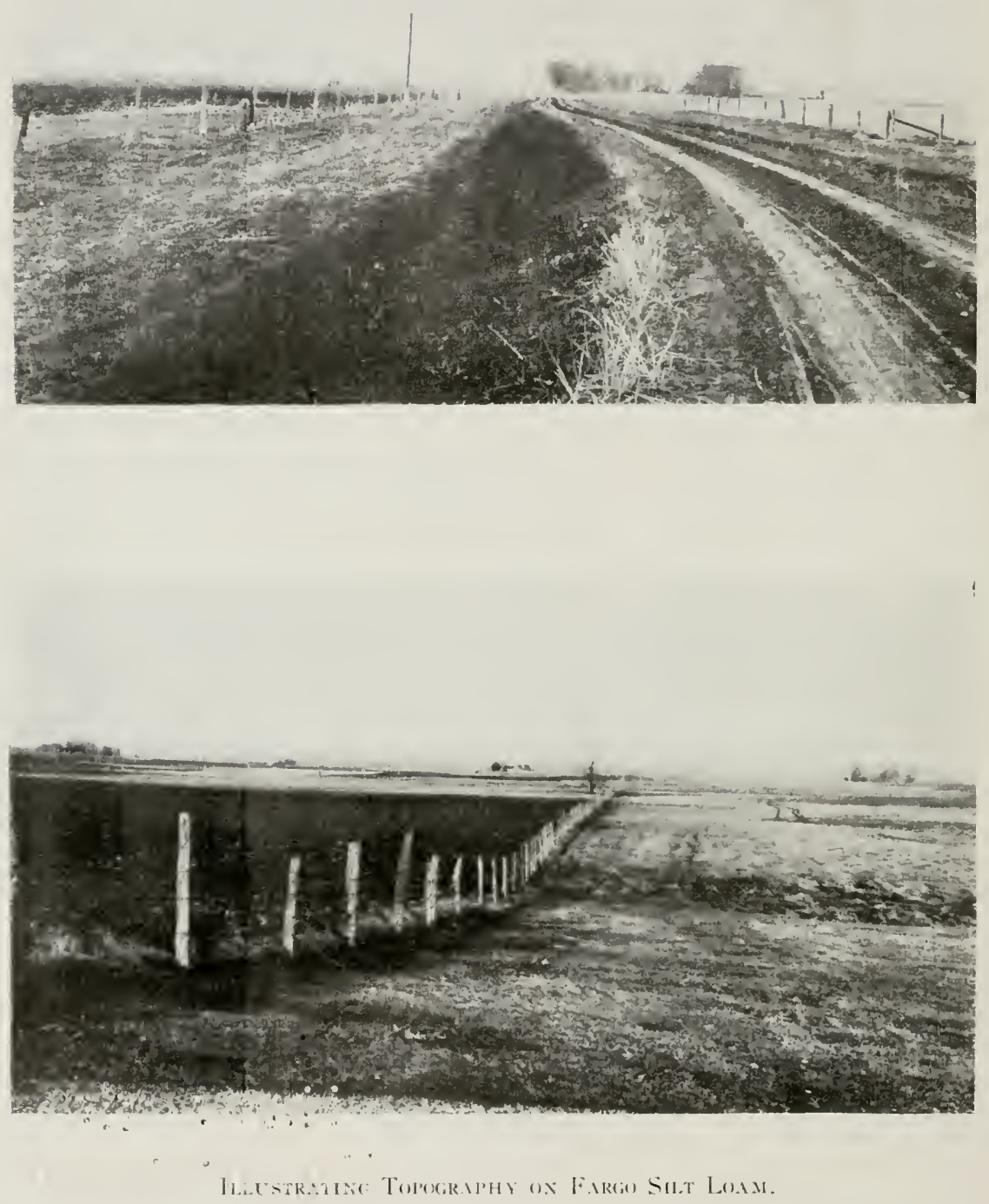

1. Field III-on the Kansan, the broad roadside strip on the left.

2. Field II-on the Late Wisconsin, at the foot of the slope and to the right of the fence. 


\section{B. LIME SUPPLY.}

\section{Carbonates.}

The carbon dioxide in the field samples is reported in tables 21 to 23. Only one determination was made for eacl sample, but a check on the accuracy of these is furnished by the determination of the amount in the "drift samples," prepared by compositing equal weights of the five field samples. The full agreement of these may be seen from the last two columns in the tables.

Carrington Silt Loam. The amount of carbonates on the Kansan is practically negligible and varies but little from field to field, the average of the carbon dioxide in the three foot section of the different fields falling between 0.051 and 0.062 per cent, with an average for all five of 0.057 (Table 21).

Table 21.-Carbon dioxide in the different sections from the five ficlds on Carrington silt loam.

Depth

$\begin{array}{cc}\text { Field } & \text { Field } \\ \text { I } & \text { II } \\ \text { per cent } & \text { per cent }\end{array}$

$\begin{array}{cc}\text { Field } & \text { Field } \\ \text { III } & \text { IV } \\ \text { per cent } & \text { per cent }\end{array}$

$\underset{\substack{\text { Field } \\ \text { per cent }}}{\text { nat }}$

$\begin{array}{ll}\text { Av. for } & \text { Drift } \\ 5 \text { fields } & \text { Sarple } \\ \text { per cent } & \text { per cent }\end{array}$

\section{KANSAN.}

$\begin{array}{llllllll}1-6 & 0.084 & 0.052 & 0.068 & 0.108 & 0.072 & 0.077 & 0.080 \\ 7-12 & 0.088 & 0.076 & 0.080 & 0.076 & 0.092 & 0.082 & 0.088 \\ 13-24 & 0.045 & 0.056 & 0.075 & 0.064 & 0.046 & 0.057 & 0.060 \\ 25-36 & 0.031 & 0.035 & 0.036 & 0.016 & 0.024 & 0.034 & 0.033 \\ \text { Average } & & & & & & \\ 1-36 & 0.054 & 0.052 & 0.062 & 0.057 & 0.051 & 0.057 & 0.05 \text { () }\end{array}$

$\begin{array}{cccccccc}1-6 & 0.112 & 0.112 & 0.048 & 0.044 & 0.064 & 0.076 & 0.072 \\ 7-12 & 0.066 & 0.042 & 0.047 & 0.070 & 0034 & 0.052 & 0.049 \\ 13-24 & 0.064 & 0.172 & 0.348 & 0.026 & 0.040 & 0.130 & 0.134 \\ 25-36 & 0.060 & 1.565 & 3.136 & 0.026 & 0.544 & 1.066 & 1.057 \\ \text { Average } & & & & & & & \\ 1-36 & 0.071 & 0.605 & 1.177 & 0.036 & 0.211 & 0.420 & 0.417\end{array}$

On the Late Wisconsin two of the fields, I and IV, show a similat low content, but two, II and III, show an appreciable amount in the second and third foot-sections, and the fifth, $V$, the third foot only. The maximum, 3.14 per cent, is found in the third foot of Field III.

It is evident that the carbonate on the Kansan has been leached out to a depth greater than three feet and that the same is true in the case of two of the fields on the Late Wisconsin, but in general the leaching on the latter has not progressed nearly so far.

Fargo Silt Loam. On this type (Table 22) the carbonate content on the Kansan varies considerably from field to field, in two, I and IV, there being no more than in the Carrington silt loam on the same drift. while in the three others an appreciable amount was found in the third foot-section. In all four sections in Field $\mathrm{V}$ the content is compara. tively high. 
In Field I on the Late Wisconsin, the carbon dioxide ranged from 2.23 per cent in the surface section to 3.99 in the third foot. this field leing the richest in carbonate of all thirty-five fields sampled. () f the four other fields, IV is the only one showing an appreciable quantity; this carrying 1.03 per cent in the third foot-section. The others average less than 0.1 per cent for the three feet. With this type in general, carbonates are higher on the Kansan than on the Jate II isconsin, the average for the latter being high only because of the large amount in Field I.

Table 22.-Carhon dionide in the different scctions from the fir' fields on liargo silt toam.

\begin{tabular}{|c|c|c|c|c|c|c|c|}
\hline $\begin{array}{l}\text { Depth } \\
\text { Inclics }\end{array}$ & $\begin{array}{c}\text { Fiell } \\
\text { I } \\
\text { per cent }\end{array}$ & $\begin{array}{c}\text { liceld } \\
11 \\
\text { percent }\end{array}$ & $\begin{array}{l}\text { Field } \\
\text { III } \\
\text { per cent }\end{array}$ & $\begin{array}{c}\text { Field } \\
\text { IV } \\
\text { per cent }\end{array}$ & $\begin{array}{l}\text { Field } \\
\text { V cent } \\
\text { per cent }\end{array}$ & $\begin{array}{l}\text { Av. for } \\
5 \text { fields } \\
\text { per cent }\end{array}$ & $\begin{array}{c}\text { Drift } \\
\text { Sample } \\
\text { per cent }\end{array}$ \\
\hline \multicolumn{8}{|c|}{ 1. Kansan. } \\
\hline $1-6$ & 0.096 & & 0.096 & 0.140 & 0.924 & 0.314 & 0.290 \\
\hline $7-12$ & 0.060 & 0.080 & 0.072 & 0.088 & 0.672 & 0.194 & 0.201 \\
\hline $13-24$ & 0.038 & 0.064 & 0.028 & 0.006 & 0.160 & 0.059 & 0.064 \\
\hline $25-36$ & 0.080 & 0.490 & 1.000 & 0.008 & 2.562 & 0.828 & 0.840 \\
\hline $\begin{array}{c}\text { Iverage } \\
1-36\end{array}$ & 0.065 & & 0.371 & 0.043 & 1.173 & 0.380 & 0.38 \\
\hline
\end{tabular}

2. Late Wisconsin.

$\begin{array}{llllllll}1-6 & 2.230 & 0080 & 0.094 & 0.097 & 0.068 & 0.511 & 0.485 \\ 7-12 & 2.410 & 0.056 & 0.108 & 0.064 & 0.064 & 0.540 & 0.570 \\ 13-24 & 2.500 & 0.036 & 0.080 & 0.034 & 0.010 & 0.530 & 0.536 \\ 25-36 & 3.990 & 0.108 & 0.036 & 1.034 & 0.020 & 1.037 & 1.040 \\ \begin{array}{c}\text { Average } \\ 1-36\end{array} & 2.937 & 0.071 & 0.072 & 0.383 & 0.032 & 0.697 & 0.701\end{array}$

Subsequent to the collection and analysis of samples from Field I it was established that although it appeared, on first inspection, that the drainage outlet was lower than the lowest point in the tract, in reality it was some feet higher, the field thus forming a part of an extınsive but very shallow "pot-hole." The drainage water accumulating in the lower part of this and evaporating would leave behind the mineral constituents leached from the surrounding uplands, thus bringing about a concentration of these, and as the drift was so well supplied with limestone the carbonate content of the soil of this field was raised to a high point.

Carrington Loam. The quantity of carbonate in the Carrington lo:am varies but little from field to field and is practically nil on both drifts, the soil having been thoroughly leached to at least three feet even on the Late Wisconsin (Table 23).

Discussion. The average amounts of carbon dioxide for the five fields on the different types on the two drifts are shown in table 24 . On the Late $W$ isconsin the averages in the three foot section are higher than on the Kansan with the exception of those for the Carrington 


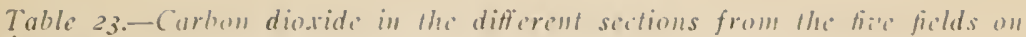
Carrington loam.

\begin{tabular}{|c|c|c|c|c|c|c|c|}
\hline $\begin{array}{l}\text { Depth } \\
\text { Inches }\end{array}$ & $\begin{array}{c}\text { Pield] } \\
1 \\
\text { per cem }\end{array}$ & 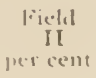 & $\begin{array}{l}\text { Field } \\
\text { III } \\
\text { per cent }\end{array}$ & $\begin{array}{l}\text { Field } \\
\text { IV } \\
\text { per cent }\end{array}$ & $\begin{array}{l}\text { Field } \\
\text { per cent }\end{array}$ & $\begin{array}{l}\text { Iv. for } \\
5 \text { ficlils } \\
\text { per cent }\end{array}$ & $\begin{array}{r}\text { Drift } \\
\text { Sample } \\
\text { per cent }\end{array}$ \\
\hline \multicolumn{8}{|c|}{ 1. KIXSAN. } \\
\hline $1-6$ & 0.066 & 0.048 & 0.072 & 0.088 & 0) 088 & 0.072 & 0.092 \\
\hline $7-12$ & 0.062 & 0.048 & 0.052 & 0.052 & 0.056 & 0.054 & 0.044 \\
\hline $13-24$ & 0.032 & 0.084 & 0.000 & 0.064 & 0.080 & 0.0 .53 & 0.032 \\
\hline $25-36$ & 0.046 & 0.076 & 0020 & 0.0 .56 & 0.060 & 0.051 & 0.040 \\
\hline $\begin{array}{l}\text { Average } \\
1-36\end{array}$ & 0.047 & (1.069 & 0.029 & 0.063 & 0.071 & 0.056 & 0.047 \\
\hline \multicolumn{8}{|c|}{ 2. LAte W1Sconsix. } \\
\hline $1-6$ & 0.110 & 0.112 & 0.002 & 0.056 & 0.072 & 0.082 & 0.100 \\
\hline $7-12$ & 0.086 & 0.04 & 0.070 & 11.040 & 0056 & 0.061 & $0.06 t$ \\
\hline $13-24$ & 0.048 & 0.036 & 0.040 & 11.044 & 0.044 & $0.0+2$ & 0.052 \\
\hline $25-36$ & 0.026 & 0.050 & 0.0 .36 & 0.108 & $0.0+2$ & 0.0 .52 & 0.044 \\
\hline $\begin{array}{l}\text { Average } \\
1-36\end{array}$ & 0.057 & 0.055 & 0048 & 0.067 & 0.050 & 0.055 & 0.1159 \\
\hline
\end{tabular}

loam. where they are alike for the two drifts. ( )n the older formation the carbonates have been leached out to a depth greater than three fee: on the two Carrington series. No serious leaching has taken place on the Fargo silt loam on either drift. On the Late Wisconsin an appreciable amount is found in the third foot on the Carrington silt loam, but practically all has been leached out of the first three feet on the Car. rington loam.

Field $V$ on the Kansan and Field I on the Late Wisconsin, on the Fargo silt loam, show a carbonate content radically different from the four other fields on their respective (lrifts, well illustrating the fact that samples from a single field cannot safely he assumed to be representative of a particular type in any given area.

Table 24.--Carbon dioxide in the different sections. The data are averages for the fie' ficlds reportid in colnum 7 of tahles 21,22 and 23.

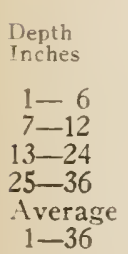

$\begin{array}{cc}\begin{array}{c}\text { Carrington silt loan } \\ \text { Kansan } \\ \text { pater cent }\end{array} & \begin{array}{c}\text { Wis. } \\ \text { per cent }\end{array} \\ 0.077 & 0.076 \\ 0.082 & 0.052 \\ 0.057 & 0.130 \\ 0.034 & 1.066 \\ & \end{array}$

.0 .057

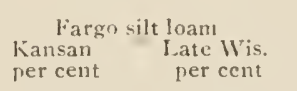

$\begin{array}{cc}\begin{array}{c}\text { Carrington loam } \\ \text { Kansan } \\ \text { per cent }\end{array} & \begin{array}{r}\text { late } \mathrm{Wis} \\ \text { per cent }\end{array} \\ 0.072 & 0.082 \\ 0.054 & 0.061 \\ 0.053 & 0.042 \\ 0051 & 0.052 \\ 0.056 & 0.055\end{array}$




\section{Reaction With Litmus.}

The reaction of both sets of samples from each field was tested with litmus paper. Strips of sensitive red and blue litmus paper were placed in direct contact with the soil, the latter was then moistened with distilled water and after a half hour the reaction was noted.

Carrington Silt Loam. On the Kansan the soils of this type (Table 25 ) all proved acid, while on the Late Wisconsin the acidity was found less general, the lower two sections being neutral in Field II and in Set 1 of Field III. The third foot in the second set of Field $V$ is also neutral.

Table 25.-Acidity as found by the litmus method. Samples taken from fire fields on Carrington silt loam.

Depth

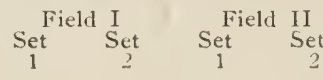

$$
\begin{array}{cccc}
\text { Field } & \text { III } & \text { Field } & \text { IV } \\
\text { Set } & \text { Set } & \text { Set } & \text { Set } \\
1 & 3 & 1 & 2
\end{array}
$$$$
\begin{array}{cc}
\text { Field } & V \\
\text { Set } & \text { Set } \\
1 & ?
\end{array}
$$

\section{Kansan.}

1-6 acid acid acid acid acid acid nent. nent. acid nent.

$7-12$ acid acid acid acid acid acid acid acid acid acid

13-24 acid acid acid acid acid acid acid acid acid acid

25-36 acid acid acid acid acid acid acid acid acid acid

2. LATE WISCONSIN.

$1-6$ acid acid acid acid acid acid acid acid acid acid

7-12 acid nent. acid acid acid nent. acid acid acid acid

13-24 acid acid neut. neut. netst. acid acid acid acid acid

25-36 acid acid nent. nent. nent. acid acid acid acid nent.

Fargo Silt Loam. Nearly all of the soils on the Kansan (Table 26) were neutral, the second set from Field III being the only one of the ten sets in which the reaction was acid for all four sections. On the Late Wisconsin the acidity was more marked, approximately half of the samples being neutral and half acid.

Table 26.-Acidity as found by the litmus method. Samples taken from fi'c fields on Fargo silt loam.

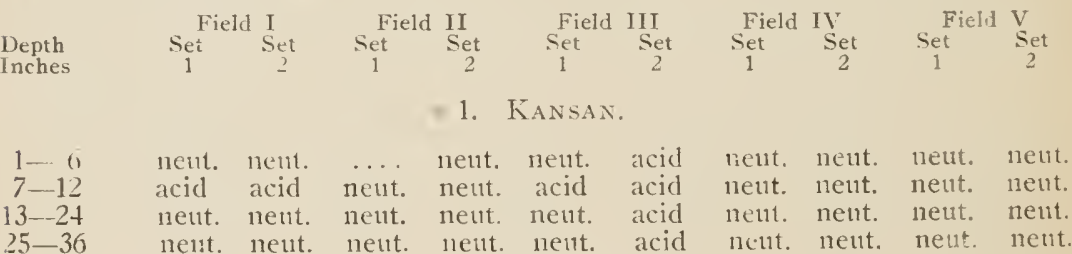

\section{LATE WISCONSIN.}

1-6 nent. nent. acid acid acid acid acid acid acid acid

7-12 neut. neut. acid acid acid acid acid acid acid nent.

13-24 neut. nent. nent. acid acid acid acid neut. acid acid

25-36 neut. nent. nent. neut. acid acid neut, neut. neut, nent.

Carrington Loam. On the Kansan (Table 27) every sample reacted acid, while on the Late Wisconsin all were acid with the exception of the surface foot in three sets. 
Table 27-- Acidity by thi litmus method. Samples talien from fir'e ficlds on Carrington loam.

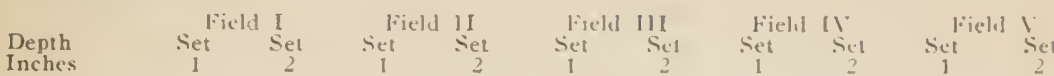

1. Kansin.

$1-6$ acid acid acid acid acid ateid acid acid acid acirl

acid acid acid acid acid acid acid nent. acid acid

acid acid acid acid acid acid acid acid acid acirl

\section{LATE WISCONSIN}

1-0 neut. neut. acid acid acid nent. acid nent. acid acid

7-12 acid nent acid acid acid acid acid nent. acid acid

13-24 acid acid acid acid acid acid acid acid acid acid

25-36 acid acid acid acid acid acid acid acid acid acid

Marshall Silt Loam. All the samples on this type (Tal)le 28) were acid with the exception of the second and third foot-sections of Set I from Field II.

Table 28.- - Icidity by the litmus method. Samples taken from fise fields of Marshall silt loam.

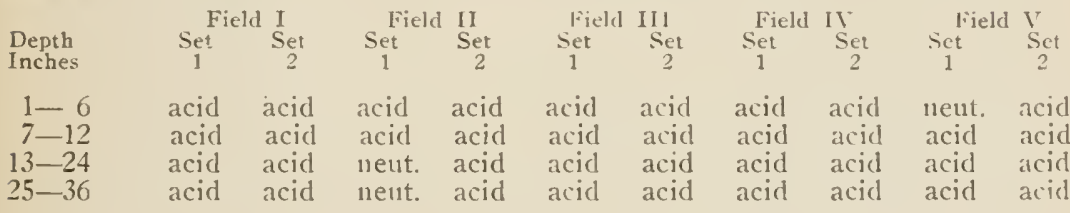

Discussion. The reaction toward litmus shows the soils of the two Carrington series on the Kansan to be more acid than those on the Late Wisconsin, while with the Fargo silt loam the opposite is true. The samples of Marshall silt loan were practically all acid.

\section{Reaction as Determined by the Truog Method.}

The reaction of the two sets of samples from each field was also tested by the Truog (30) method. This method is briefly as follows: To 10 grams of soil a re added 1 gram calcium chloride. 0.1 gm. zinc sulfide and 100 c.c water. The mixture is thoronghly sliaken, heated to boiling and after hoiling one minute a strip of learl acetate paper is placed over the mouth of the flask and the boiling continned two minutes longer, when the paper is removed. If the soil is acid the paper will be darkened on the under side in proportion to the degree of acidity.

The results obtained by this method are reported in tables 29 to 32 , and since they so closely resemble those secured by the litmus method need no further discussion. I comparison of the indications obtained by the two methods is given helow. 
Table 29.- Icidity of Carrington silt loam soil as indicated by the Truog method.

1)epth

lnches

$1-6$

$7-12$

$13-24$

$25-36$

$\frac{1-6}{7-12}$

$7-12$
$13-24$

$25-36$

$$
\begin{array}{llll}
\text { Set } & \text { Sield } & \text { Jield } & \text { IJ } \\
1 & 2 & 1 & \text { Set }
\end{array}
$$

$\begin{array}{lcc}\text { 1] } & \text { jield } & \text { III } \\ \text { Set } & \text { Set } & \text { Set } \\ 1 & 1 & 2\end{array}$

1. KANSAN.

med. nued. med. str. nued. ned. str. nued. nued. nued. med. sl. med. med. med. med. str. med. med. sl.

v. str. nled. med. med. str. str. v.str. l.str. str. str. med. v.sl. sl. med. sl. med. med. str. sl. med.

2. LATE WISCONSIN.

sl. med. sl. v. sl. sl. med. ned. med. med. med. med. sl. v.sl. v.sl. sl. med. med. sl. sl. sl. v. sl. sl. v.sl. neut. neut. med. sl. sl. v. sl. sl. sl. neut. neut. neut. neut. sl. v.sl. v.sl. v.sl. neut.

neut. = neutral; v. sl. - very slight; sl. = slight; med. = medium; str. = strong; v. 4 t\%. = very stiong. Table 30. - Acidity of Fargo silt loam soil as indicatid by the Truog method.
Field I

$\begin{array}{ccc}\text { Set } & \text { Set } & \text { Set } \\ 1 & 2 & 1\end{array}$

$\begin{array}{ccccccc}\text { Set } & \text { Set } & \text { Set } & \text { Set } & \text { Set } & \text { Set } & \text { Set } \\ 2 & 1 & 2 & 1 & 2 & 1 & 2\end{array}$

1- 6 sl. sl. neut. neut. sl. med. neut. neut. neut. neut.

y-12 sl. v.sl. neut. neut. v.sl. ned. neut. neut. nent. neut.

$13-24$ neut. neut. neut. neut. neut. sl. neut. neut. neut. neut.

35-30 neut. neut. neut. neut. neut. v. sl. neut. neut. neut. neut.

2. LATE IVISCONSIN.

$1-6$ neut, neut. med. nied. med. med. sl. sl. sl. v. sl.

$7-12$ neut. nent. v.sl. med. sl. v.sl. sl. visl. sl. v. sl.

$13-24$ neut. neut. neut. v.sl. v.sl. neut. v.sl. neut. v. sl. neut.

25-36 neut. neut. neut. neut, nent. neut. neut. nent. neut. neut.

Table 3x.-Acidity of Carrington loam soil as indicated by the Truog method.

$\begin{array}{lccccccccc} & \text { Firld I } & \text { Field II } & \text { Field III } & \text { Field IV } & \text { Field V V } \\ \text { Depth } & \text { Set } & \text { Set } & \text { Set } & \text { Set } & \text { Set } & \text { Set } & \text { Set } & \text { Set } & \text { Set } \\ \text { Inches } & 1 & 2 & 1 & 2 & 1 & 2 & 1 & 2 & 1\end{array}$

$1-6$ sl. str. str. str. str. str. str. str. med. ined.

7-12 sl. str. str. str. med. med. med. str. med. str.

13-24 v. sl. med. str. med. str. str. med. med. str. v. str.

$25=-36$ v. sl. sl. v.si. v.sl. v.sl. str. sl. v. sl. 1med. str.

2. LATE WISCONSIN.

1 - 6 sl. r. sl. sl. sl. med. med. sl. v. sl. str. med.

$7-12$ sl. v. si. sl. sl. str. med. sl. v. sl. med. sl.

13-24 med. si. sl. sl. str. str. sl. v. sl. med. sl.

25-36 str. sl. sl. sl. med. sl. v. sl. neut. sl. sl.

Tahle 32.-Acidity of Marshall silt loam soil as indicated by the Truog method.

1)epth
Inches $\begin{array}{cc}\text { Field } & \text { I } \\ \text { Set } & \text { Set } \\ 1 & 2\end{array}$ Field I
Set Set

\section{KANSAN.}

1. 6 str. med. v. sl. str. v. str. str. med. med. med. str. $7-12$ str. str. v. sl. med. v. str. str. v.sl. sl. med. med. $13-24$ str. med. neut. med. v.str. v.str. med. med. str. med. 25-36 med. v. sl. nent. sl. v. str. str. med. v. sl. med. sl. 


\section{Coloration of Ammonia Solution.}

The intensity of coloration of the anmonia extract ats an indication of the decree of acidity (33) was tested on only the two upper sections, the smaller amounts of organic matter present in the two lower sections precluding the use of this method. Twenty grams of air-clry soil was treated with $250 \mathrm{cec}$ of + per fent ammonia, well shaken and allowed to stand for eight days, when portions were drawn off and compared with a standard solution in a colorimeter. The standard solution was made up from one of the soil extracts which had been drawn off from what appeared to be the darkest in the series. A column of this solution $11.7 \mathrm{~cm}$. high shut out all the light coming through an aperture $1 \mathrm{~cm}$. in rlameter from a new 25-watt Mazcla lamp when tested in a dark room. The standard was made loy diluting $100 \mathrm{cc}$ of this solution to $1^{9} 0 \mathrm{cc}$. with distilled water. In comparing the test solutions with the standard a column of the former $10 \mathrm{~cm}$. in height was employed and the data reported in tables 33 and 34 are the heights in centimeters of columns of standard refuired to exactly equalize this. All solutions were brown in color, there being none of the black color often obtained in the determination of humus (maticre noire of Grandeat1).

On the second dis after starting the extraction eight of the solutions, ranging in color from dark to light, and representing the different types, were selected and comparisons with the standard were made daily in order to determine when the increase in depth of color ceased. The results are shown in table 33 . Thus, at the time of reading on the

Table 33.-Proportional amounts of coloring matter itrtrated by ammonia from day to day.

Time of

extraction

days

$\begin{array}{ll}2 & 10 \\ 3 & 13 \\ 4 & 13 \\ 5 & 14 \\ 6 & 16 \\ 7 & 17 \\ 8 & 19\end{array}$

$\begin{array}{rr} & \text { Kim-an } \\ 2 & 3 \\ 8 & 2 \\ 12 & \cdots \\ 13 & 3 \\ 14 & 3 \\ 14 & 3 \\ 16 & 4\end{array}$

$\begin{array}{lr}i & 1 \\ \cdots & 9 \\ \cdots & 9 \\ \cdots & 11 \\ 2 & 12 \\ \frac{2}{2} & 12 \\ & 11\end{array}$

$\begin{array}{ccc}\text { latte } & \text { Hinconsin } & \\ 2 & 3 & 4 \\ 5 & 5 & 2 \\ 6 & 5 & 2 \\ 6 & 5 & 2 \\ 6 & 5 & 2 \\ 7 & 5 & 3\end{array}$

sixth day it resumed a higher colum of stamelarel to match the elepth of color in Nos. 1.2 and 4 on the Kansan and No. 1 on the Late IVisconsin than it had on the previous day, while in . Vo. 3 on the Kansan? and Nos. 2, 3 and $t$ on the I ate Wisconsin the test showerl that no more coloring matter had been extracted during this period. During the seventh day but little increase in the elepth of color occurred. Then all solutions were shaken and on the next day they were compared with the standard. The eight test solutions showed it sligh increase in the deptli of color over the previous day, undoubtedly due to the last shaking. 
焉焉

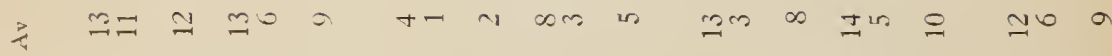

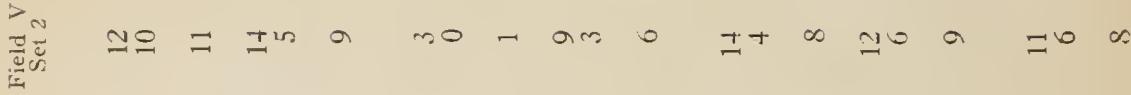

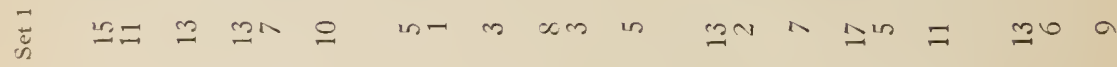
立 $匚$ ป

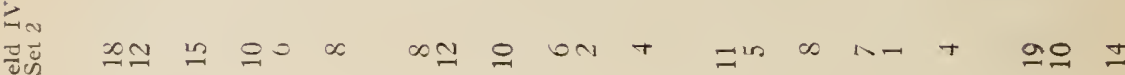
is

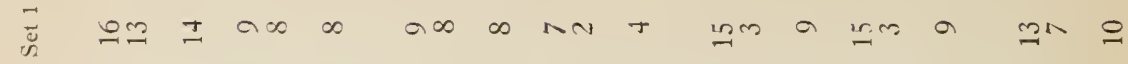
$\stackrel{3}{\stackrel{3}{3}}$

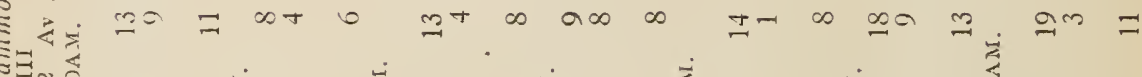

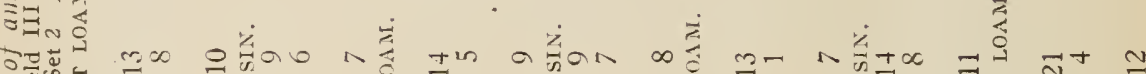

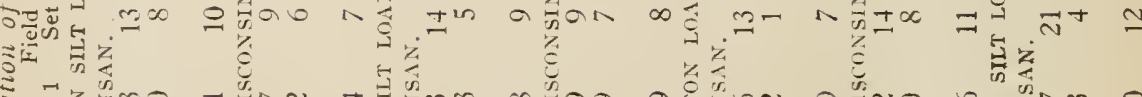

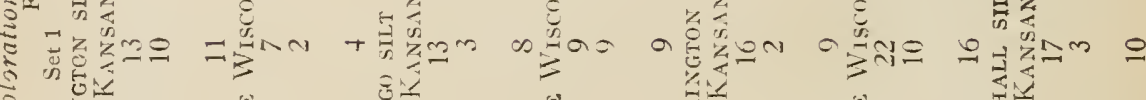
की

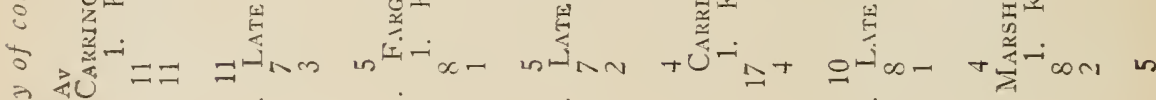

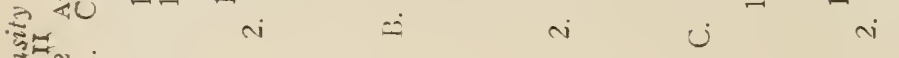

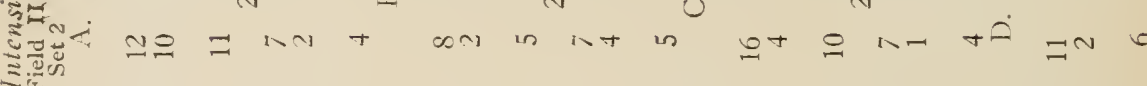
के $\frac{1}{3}$

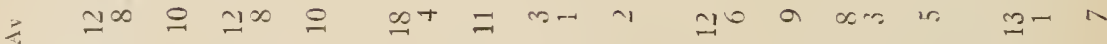

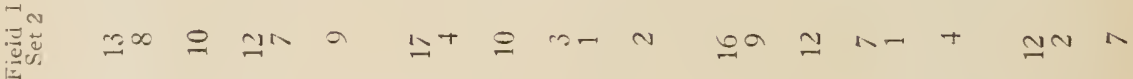

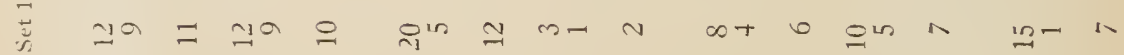

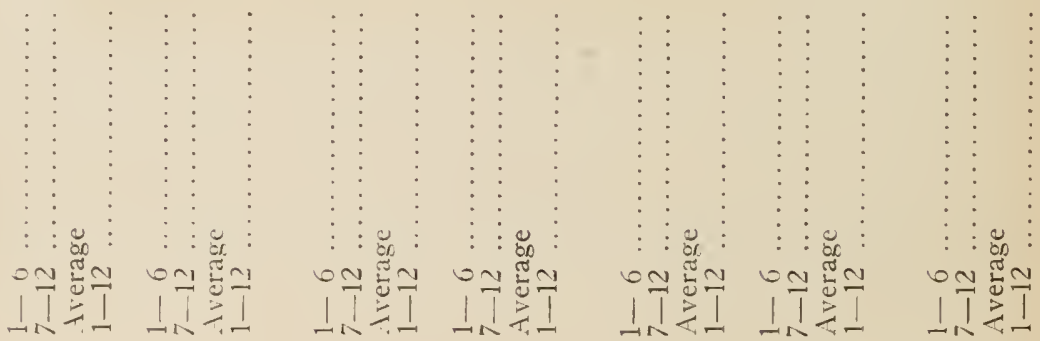



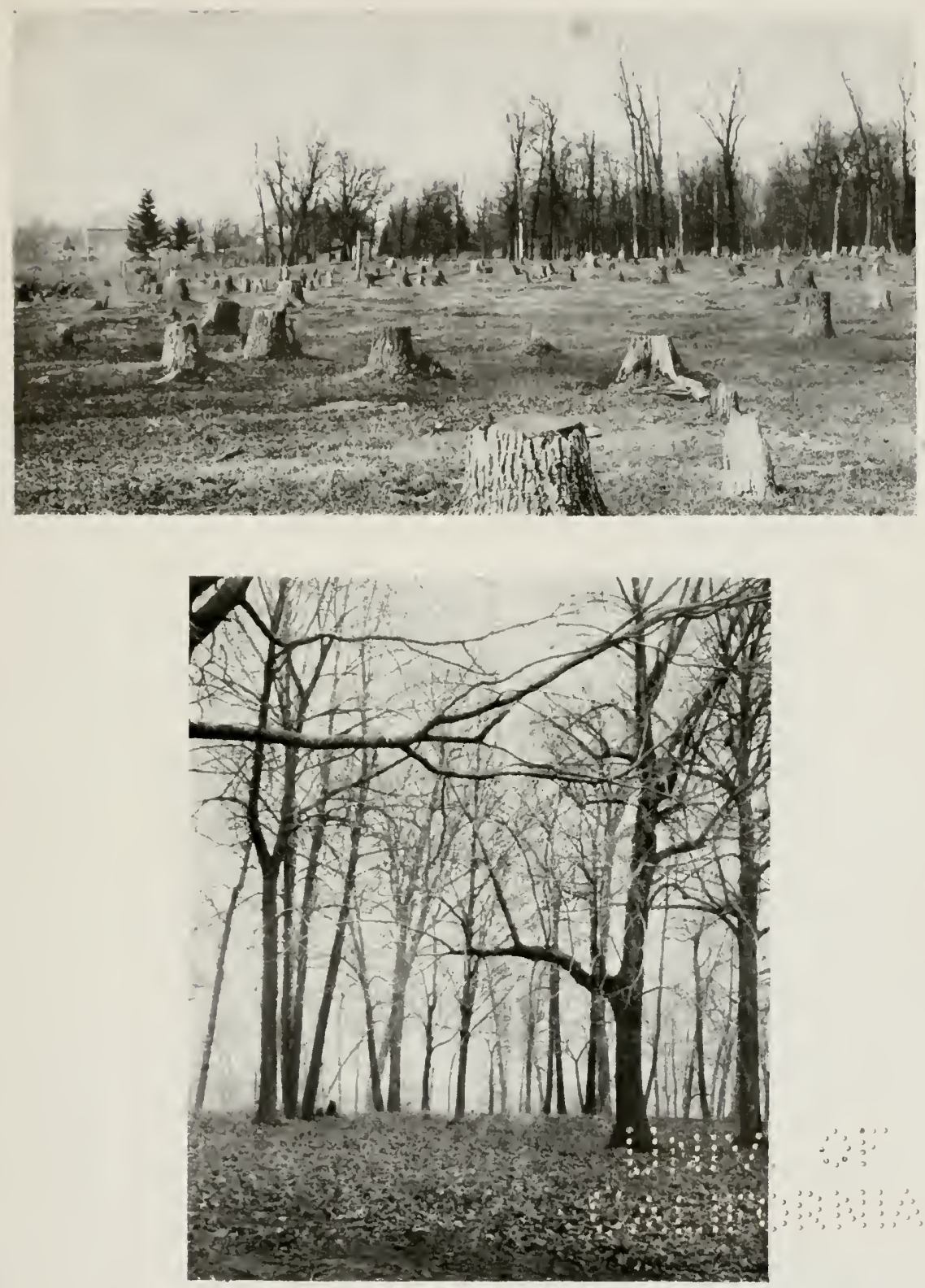

ILLCSTRATING Ch.iRACTER OF VegetatION oN CiRRINGTUN LOAM.

1. Field $\mathrm{V}$-on the Kansan, the portion with the trees still standing.

2. In the mirlst of field IV-on the Jate Wisconsin, showing the cover of leaves on the forest floor. 



\section{Comparison of Indications Obtained by Different Methods.}

\section{Comparison of Indications Obtained By Truog and Litmus} Methods. There is a creat similarity between the indications obtained by the Truog and the litmus methods as carried out in the present study. For the most part, the reactions are the same if, in the Truog test, we indicate any degree of aciclity simply "acid." "The discrepancies are, in the main, between samples which show only a slight acidity by the Truog methorl, most of these heing neutral to litmus.

It might be mentioned here that it so happened that the tests with litmus were made after the soils had been arranged in order of their color (p. 58) so that soils from the different sets. fields, types and drifts were promiscuously intermingled, and it was only after the reaction had been determined and recorded and the data reassembled that the first intimation of the relation of reaction to type and drift was olitained.

Comparison of Reaction By the Truos Hethod and the Carbonate Content. A relation hetween the degree of acidity shown hy Truogs test and the cathonate content, as shown by the jercentage of carbon dioxide (Tables 21 to 23 ), may be pointed out. Where the content of carbon dioxide is above 0.11 per cent no acidity is slown. In the case of surface soils there seems to be no doubt but that some organic matter is decomposed during the course of the carbon dioxide determination with the evolution of carbon dioxicle and the percentage thus raised slightly. Hence, it appears safe to assume that the showing of even a very slight acidity by the Truog test indicates that carbonates in any form are either lacking or present in so small an amount as to be of no consequence.

comparison of Reaction By Litmus Method with the Carbonate Contcut. Since the indications attained by the litmus method agree so well with those obtained by the Truog test, the same seneral agreement between the reaction shown by it and the carbonate content monkd be expected. and this is found to be true.

Comparison of Indications Furmished By the Litmus. Truog and Immonia Mcthods. The results obtained by the ammonia method agree only in a very general way with those found by the Truog and litmus methods. Between the regree of acidity from field to field as shown by the ammonia method, on one hand, and the Truog and litmus methods on the other, there is no relation. Nor does it appear possible to select any arbitury number of units of color in the first corresponding with any particular decree of acidity is established by the second. 


\section{Relation of Calcareousness to Texture.}

The variation in texture of the samples from the four types used in this study, as expressed by the moisture equivalents (Table 20). varies rather widely, the highest average for a type being 32.2 and the lowest 21.0. Each type was found to have practicaily the same texture on both drifts.

One relation between the textnre and calcareousness should be pointed out. The Fargo silt loam, which on both drifts has the finest texture, still has carlonate in the surface six inches. The Carrington silt loam, next finest in texture, still has carbonate present in the second and third foot-sections on the Late $1 \mathrm{I}$ isconsin, but none on the Kansan, while the Carrington loam, which has the coarsest texture of all the type studied, shows no carbonate in the first three feet on either drift, the leaching having carried it below this level even on the more recent formation. However, it should be borne in mind that the first-named type has the most imperfectly developed natural surface drainage and the last the hest. the Carrington silt loam occupying an intermediate position.

\section{Relation of Calcerousness to Age of Drift.}

As pointed out above the texture of the soil on each of the threc types is quite uniform from drift to drift. So, any difference in the amount of calcium carbonate between soils fron any one type on the two drifts must be due, not to difference in texture and hence to differences in the rate of percolation, but to the age of the drift. In the samples from the Fargo silt loam carbonate is found on both drifts and no difference in the degree of leaching is shown. On the Carrington loam the carbonate has been leached out of the first three feet on both drifts, so that it is only in the soils from the Carrington silt loam that any relation between the calcareousness of the soil and the age of the drift will be apparent. In the soils from this type on the Kansan no carbonate is found above the three foot level but in the majority of fields on the Late Wisconsin it occurs in the third foot-section and in some instances in the second, indicating that leaching has proceeded farther on the Kansan. 


\section{INORGANIC CONSTITUENTS.}

\section{Methorls of Chemical Analysis.}

The drift samples from the three glacial types were subjected to a complete or rock analysis. In the case of the individual field samples, determinations of only carbon dioxide and phosphoric acid were made.

The methods of analysis employed were those used in the laboratory of the United States Geological Survey (19) except in the case of phosphoric acid. In (letermining this extremely important constituent by the methorl used in that laboratory such discordant results were obtained that the main investigation was halted until a satisfactory method for the determination of total phosphoric acid could be developed. The author (2S) has already published an account of this subsidiary investigation.

The method for the determination of phosphoric acid thus developed is briefly as follows: One gram of dro soil is weighed into a platinum dish of appropriate size and igniter in the muftle at dull red heat a sufficient length of time to insure the complete oxiclation of the organic matter. After cooling. $10 \mathrm{cc}$. of distilled water. $10 \mathrm{cc}$. of nitric acid and $5 \mathrm{cc}$. of hydrofluoric acid are added, the mixture well stirred, and the contents of the dish evaporated on the steam bath until approximately $5 \mathrm{cc}$. remain, when an atditional $5 \mathrm{cc}$ of hydrofluoric acid are added, the mixture again well stirred, and the evaporation continued to complete dryness. Exapuration with small quantities of nitric acid is repeated two or three times. After the final evaporation the residue is dried at 110 degrees $C$. in the air-bath for an hour or two in order, as IVashington (32, p. 16.3) states, "to render insoluble any silica which might otherwise come down with the phosphorus." When cool the resirlue is taken up, with $3 \mathrm{cc}$ of concentrated nitric acid and $7 \mathrm{cc}$. of distillerl water, boiled gently for a few minutes, and after coolinw somewhat, is filtered and washed: the phosphorus in the filtrate is precipitated with ammonium molybdate, and finally weighed as magnesium pyrophosphate. IVith soils poor in phosphorus a larger sample of soil should be taken and the amounts of the reacents proportionately increasecl.

It was later ascertanined that if about $15 \mathrm{cc}$ of boiling hot water be adcled after treating the residuc with $3 \mathrm{cc}$ of nitric acid and the contents of the dish stirred and set aside for 5 or 10 minutes, instead of bringing this to boiling. the time of filtering could be considerably shortenerl without lesiening the accuracy of the metlosl. 
The general scheme for the determination of the other inorsanic constituents is briefly outlined in the following sentences: One gram of dry soil was weighed into a $25 \mathrm{cc}$. platinum crucible and ignited in the muffle at a dull red heat for a sufficient length of time to destroy all organic matter, when it was remoied, cooled and weighed. The difference between this and the original weight gives the iolatile matter.

The ignited soil was then fused with five grams of sodium carbonate and the melt digested some time with hot water, acidified with hydrochloric acid and finally evaporated to drrness. This was extracted with warm dilute hychrocloric acid and the resillue filtered off. dried, ignited and weighed. It was then treated with hydrofluoric acid, evaporated to dryness, ignited and again weiohed, the difference between the two weights giving the anomnt of silica.

In the filtrate the sesquioxides of iron, aluminum, phosphorus and titanimm were precipitaterl with ammonia, filtered off, placed in the same crucible with traces of these left from the silica. (lried, ignited and weighed. The combinert oxides were fused with potassimm pyrosulphate, the melt dissolved in water to which a few cubic centimeters of sulphuric acil had been added, filtered, and the residue isnited, weigherl and evaporated with hydrottuoric acid. It was then isnites and arain weighed, the loss in weight representing a last trace of silica included in the combined oxides, this being added to the amonnt first obtained.

In the filtrate from the pyrosulphate fusion the iron was reduced with hydrogen sulphide and titrated with permanganate and the titanimm deternined colorimetrically in this solution after the faint permanganate tint had clisappeared. The phosphorus was determined in a separate sample as described above. When the amounts of iron, titanium and phosphorus were deducted from the amount of combined oxides the quantity of almmina was obtained.

In the filtrate from the sespuioxide precipitation, the lime wa: thrown down with ammonimm nxalate and subseguently determined by titration with permanganate.

The magnesia was precipitated in the filtrate after the removal of the lime and finally weighed as magnesium pyrophosphate.

The potash and soda were letermined by the Iawrence Smith methorl $(29)$.

The analrtical clata are the averages of concordant duplicate determinations.

The inorganic comstituents in the varions soil trpes on the different drifts are shown in tables 35 to 37 . To make evident the variationin inclividual constituents these are dealt with separately in later tables 
Table 35-Composition of Carringtun silt loam.

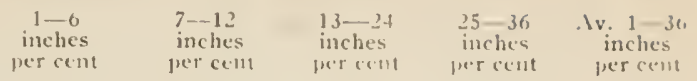

1. KAxsix:

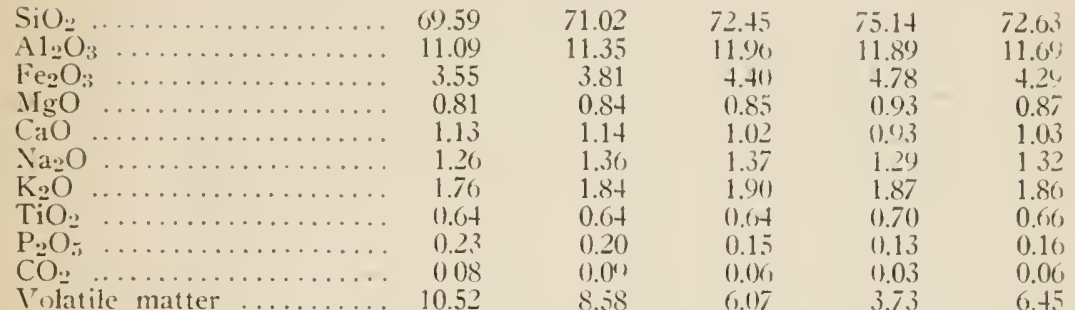

2. LATE MISCONSIN.

\begin{tabular}{|c|c|c|c|c|c|c|}
\hline $\mathrm{SiO}_{2}$ & & 72.89 & 73.62 & 75.24 & 73.6 .5 & 74.05 \\
\hline $\mathrm{Al}_{2} \mathrm{O}_{3}$ & $\ldots \ldots \ldots \ldots \ldots \ldots$ & 10.46 & 10.87 & 11.35 & 12.13 & 11.38 \\
\hline $\mathrm{Fe}_{2} \mathrm{O}_{3}$ & $\ldots \ldots \ldots \ldots \ldots \ldots$ & 2.99 & 3.21 & 3.42 & 3.81 & 3.44 \\
\hline $11 \mathrm{gO}$ & $\ldots \ldots \ldots \ldots \ldots \ldots \ldots$ & 0.72 & 0.74 & 0.88 & 1.21 & 0.94 \\
\hline $\mathrm{CaO}$ & $\ldots \ldots \ldots \ldots \ldots \ldots \ldots \ldots$ & 1.24 & 1.18 & 124 & 2.08 & 1.51 \\
\hline $\mathrm{Na}_{2} \mathrm{O}$ & $\ldots \ldots \ldots \ldots \ldots \ldots \ldots$ & 139 & 1.35 & 1.3 .3 & 1.31 & 1.3 .3 \\
\hline $\mathrm{K}_{2} \mathrm{O} \ldots$ & $\ldots \ldots \ldots \ldots$ & 1.66 & 1.74 & 1.86 & 1.87 & 1.81 \\
\hline $\mathrm{TiO}_{2}$. & $\ldots \ldots \ldots \ldots$ & 0.50 & 0.52 & $0.5 t$ & 0.53 & 0.5 .3 \\
\hline $\mathrm{P}_{2} \mathrm{O}_{5}$ & $\cdots \cdots$ & 0.18 & 0.17 & 0.14 & 0.11 & 0.14 \\
\hline & $\ldots \ldots \ldots \ldots \ldots \ldots \ldots$ & 0.07 & 0.05 & 0.13 & 1.06 & 0.42 \\
\hline & e matter ........... & 9.38 & 7.80 & 5.34 & 2.99 & 5.614 \\
\hline
\end{tabular}

Table 36.-Composition of Fargo silt lonm.

\begin{tabular}{|c|c|c|c|}
\hline$\overline{c h e s}^{6}$ & $\begin{array}{l}7 \text {-12 } \\
\text { inches }\end{array}$ & $\begin{array}{l}13-24 \\
\text { inches }\end{array}$ & $\begin{array}{l}25-30 \\
\text { inches }\end{array}$ \\
\hline
\end{tabular}

1. Kixsix.

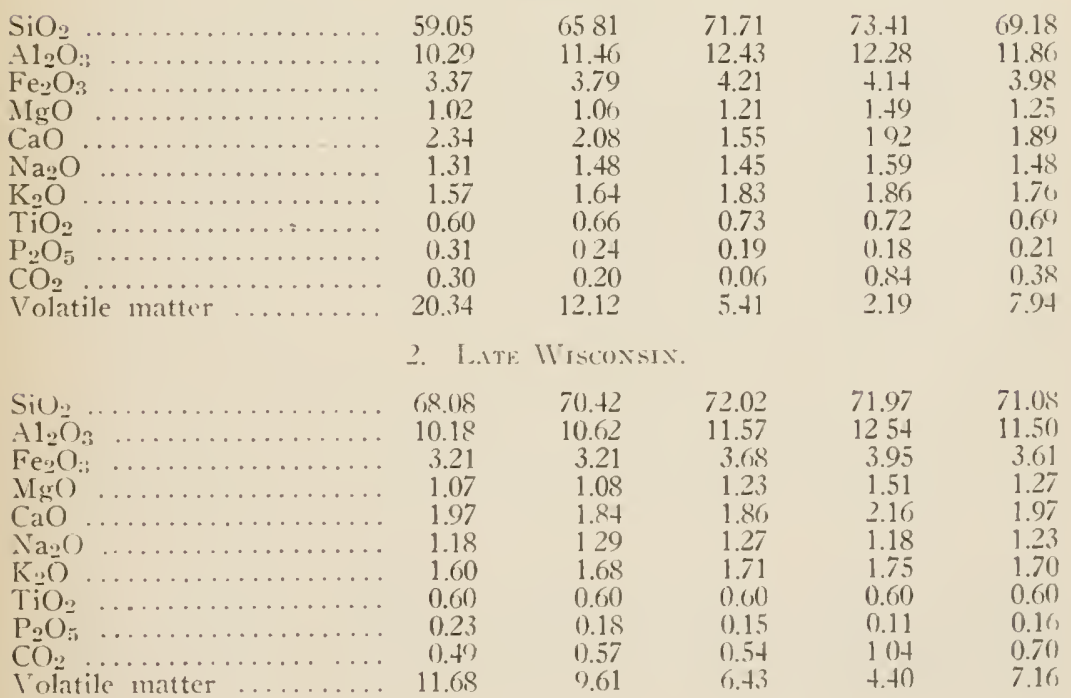


Table 37.-Composition of Carrington loam.

$\begin{array}{rrrrr}\begin{array}{c}1-6 \\ \text { inches } \\ \text { ier cent }\end{array} & \begin{array}{c}7-12 \\ \text { inches } \\ \text { percent }\end{array} & \begin{array}{r}13-24 \\ \text { inches } \\ \text { percent }\end{array} & \begin{array}{r}25-36 \\ \text { inches } \\ \text { per cent }\end{array} & \begin{array}{r}\text { Av } 1-3 \\ \text { inches } \\ \text { per cent }\end{array} \\ 75.69 & 77.05 & 74.95 & 78.23 & 76.52 \\ 9.50 & 10.54 & 12.01 & 10.46 & 10.83 \\ 2.93 & 3.41 & 4.23^{*} & 4.04 & 3.81 \\ 0.70 & 0.71 & 0.94 & 0.78 & 0.81 \\ 1.06 & 0.92 & 0.97 & 1.02 & 0.99 \\ 1.46 & 1.42 & 1.38 & 1.41 & 1.41 \\ 1.72 & 1.76 & 1.82 & 1.65 & 1.74 \\ 0.65 & 0.73 & 0.69 & 0.60 & 0.67 \\ 0.23 & 0.18 & 0.18 & 0.15 & 0.18 \\ 0.09 & 0.04 & 0.03 & 0.04 & 005 \\ 6.41 & 3.73 & 3.32 & 2.66 & 3.68\end{array}$

2. LATE WISCONSIN.

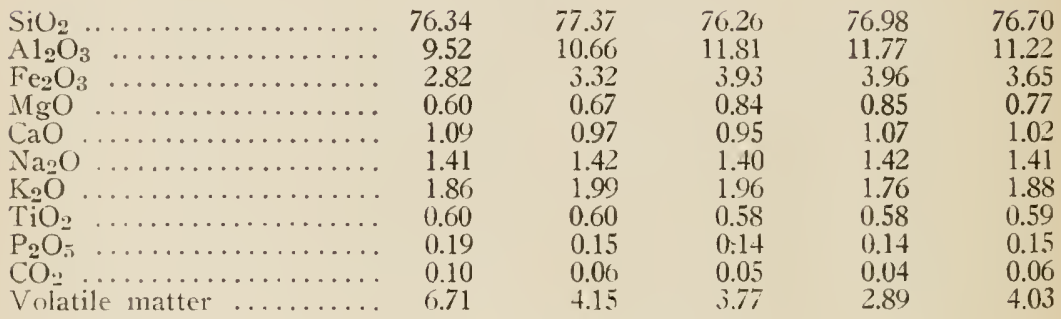

\section{Silica.}

The silica (Table 38) is quite uniformly distributed on the two drifts, the amounts differing slightly, however, from type to type. The lowest averages are those for the Fargo silt loan and the highest those for the Carrington loam. On the Kansan, the former, in the first 6-inch section, shows only 59.05 per cent, but this does not appear so strange when we take into consicleration the fact that this soil carries over 20 per cent of volatile matter. On the Lansan, the maximtm appears in the lowest section, while on the Late Wisconsin it is reached in the second foot or the lower lialf of the first. The soils on the younger drift are, on the average, somewhat richer in silica and the maximum amount is found at a higher level.

Table 38 .-Silica in the different sections.

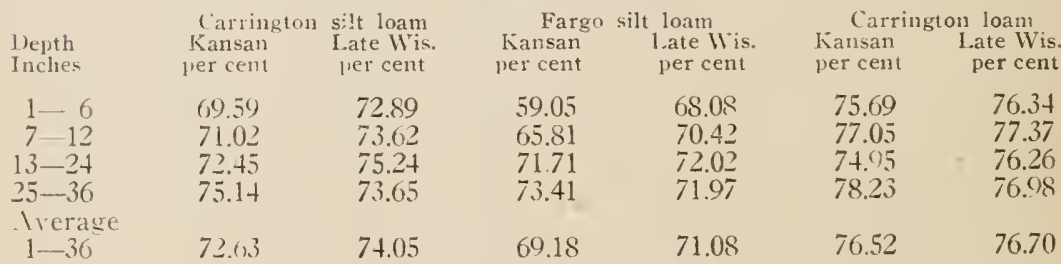




\section{Iron.}

The iron is reported as ferric oxicle in table 3 . The distribution is quite uniform from trpe to type and from drift to drift. On the Kansan, all three types show a higher content than on the Late Wisconsin, and, on the latter, the average percentages are almost identical. The difference between drifts is greatest on the Carrington silt loam where, in the second and third foot-sections, it amounts to 1.0 per cent. and least on the Carrington loam, which exhibits a remarkable parallelism also in the case of practically all other constituents. On the Kansan, the maximum on two of the thrce types is shown in the second foot-section, while on the Late Wisconsin it is found in the third foot.

Table 39--Ferric oxide in the different sections.

\begin{tabular}{|c|c|c|c|c|c|c|}
\hline \multirow[b]{2}{*}{$\begin{array}{l}\text { Depth } \\
\text { Inches }\end{array}$} & \multirow{2}{*}{$\begin{array}{l}\text { Carrington } \\
\text { Kansan } \\
\text { percent }\end{array}$} & \multirow{2}{*}{$\begin{array}{l}\text { silt loam } \\
\text { l.ate Wis. } \\
\text { per cent }\end{array}$} & \multicolumn{2}{|c|}{ Fargo silt loam } & \multicolumn{2}{|c|}{ Carrington loam } \\
\hline & & & $\begin{array}{l}\text { Kansan } \\
\text { per cent }\end{array}$ & $\begin{array}{l}\text { Late Wis. } \\
\text { per cent }\end{array}$ & $\begin{array}{l}\text { Kansan } \\
\text { per cent }\end{array}$ & $\begin{array}{l}\text { Late Wis. } \\
\text { per cent }\end{array}$ \\
\hline $1-6$ & 3.55 & 2.99 & 3.37 & 3.21 & 2.93 & 2.82 \\
\hline $7-12$ & 3.81 & 3.21 & 3.79 & 3.21 & 3.41 & 3.32 \\
\hline $13-24$ & 4.40 & 3.42 & 4.21 & 3.68 & 4.23 & 3.93 \\
\hline $25-36$ & 4.78 & 3.81 & 4.14 & 3.95 & 4.04 & 3.96 \\
\hline Average & & & & & & \\
\hline $1-36$ & 4.29 & 3.44 & 3.98 & 3.61 & 3.81 & 3.65 \\
\hline
\end{tabular}

4. Alumina.

The total alumina (Table 40) is very uniformly distributed on the two drifts as well as from type to type, on the Kansan showing a minimum of 9.50 per cent and a maximum of 12.43 per cent and, on the Late Wisconsin, a range from 9.52 to 12.54 per cent.

Table 10.-Alumina in the different sections.

\begin{tabular}{|c|c|c|c|c|c|c|}
\hline \multirow[b]{2}{*}{$\begin{array}{l}\text { Uepth } \\
\text { Inches }\end{array}$} & \multirow{2}{*}{$\begin{array}{l}\text { Carringto } \\
\text { Kansan } \\
\text { per cent }\end{array}$} & \multirow{2}{*}{$\begin{array}{l}\text { silt loam } \\
\text { Late Wis. } \\
\text { per cent }\end{array}$} & \multicolumn{2}{|c|}{ Fargo silt loam } & \multicolumn{2}{|c|}{ Carrington loam } \\
\hline & & & $\begin{array}{l}\text { Kansan } \\
\text { per cent }\end{array}$ & $\begin{array}{l}\text { Late Wis. } \\
\text { per cent }\end{array}$ & $\begin{array}{l}\text { Kansan } \\
\text { per cent }\end{array}$ & $\begin{array}{l}\text { Late Wis. } \\
\text { per cent }\end{array}$ \\
\hline $1-6$ & 11.09 & 10.46 & 10.29 & 10.18 & 950 & 9.52 \\
\hline $7-12$ & 11.35 & 10.87 & 11.46 & 10.62 & 10.54 & 10.66 \\
\hline $13-24$ & 11.96 & 11.35 & 12.43 & 11.57 & 12.01 & 11.81 \\
\hline $25-36$ & 11.89 & 12.13 & 12.28 & 12.54 & 10.46 & 11.77 \\
\hline $\begin{array}{c}\text { Average } \\
1-36\end{array}$ & 11.69 & 11.38 & 11.86 & 11.50 & 10.83 & 11.22 \\
\hline
\end{tabular}

In the vertical distribution the maximum, as in the case of the ferric oxide, on the Kansan, is to be found in the second foot and on the Late Wisconsin in the third foot, the opposite of what was found for silica. The percentages in the upper sections are not as large as those in the lower ones. which is to be explained by the downward translocation of colloidal clay.

The similarity in the alumina content on the two drifts is evident from the averages for the three-foot sections on all three types, viz.. 11.46 per cent on the Kansan and 11.37 per cent on the Late Wisconsin. 


\section{Titanium.}

The titanium (Table 41 ) is very uniformly distributed on the two Irifts, and on the three types as well. The amounts found on the Kansan are slightly higher in all cases than those found on the Late $1 \mathrm{~V}$ isconsin, thus resembling the alumina in distribution.

Table HI.-Titunium in the difficent sections.

\begin{tabular}{|c|c|c|c|c|c|c|}
\hline & Carrington & silt loam & Fargo & silt loam & Carris & on loatn. \\
\hline $\begin{array}{l}\text { Jepth } \\
\text { Inches }\end{array}$ & $\begin{array}{l}\text { Kansan } \\
\text { ler cent }\end{array}$ & $\begin{array}{l}\text { Late Wis. } \\
\text { jer cent }\end{array}$ & $\begin{array}{l}\text { Kansan } \\
\text { per cent }\end{array}$ & $\begin{array}{l}\text { Late Wis. } \\
\text { per cent }\end{array}$ & $\begin{array}{l}\text { Kansan } \\
\text { per cent }\end{array}$ & $\begin{array}{l}I \text { ate } W \text { is. } \\
\text { per cent }\end{array}$ \\
\hline $1-6$ & 0.64 & 0.50 & 0.60 & 0.60 & 0.68 & 0.60 \\
\hline $7-12$ & 0.64 & 0.52 & 066 & 0.60 & 0.73 & 0.60 \\
\hline $13-24$ & 0.64 & 0.54 & 0.73 & 0.60 & 0.69 & 0.58 \\
\hline $25-36$ & 0.70 & 0.53 & 0.72 & 0.60 & 0.60 & 0.58 \\
\hline $\begin{array}{l}\text { Iverage } \\
1-36\end{array}$ & 0.66 & 0.53 & 0.69 & 0.60 & 0.67 & $0.5^{\circ}$ \\
\hline
\end{tabular}

\section{Lime.}

The total lime (Table +2, part 1) varies almost directly with the carbon dioxide. On the Carrington silt loan the amount in the first three sections is practically the sane on both drifts, varying between 1.0 and 1.25 per cent. In the third foot, however, the quantity on the Late $W$ isconsin is more than twice as great, reaching 2.08 per cent, as compared with 0.93 per cent on the Kansan.

On the Fargo silt loam there is not a wide difference between the amounts of this constituent in the different sections on either drift, and the average for the three feet is 1.89 per cent in the case of the Kansan and 1.97 per cent in that of the Iate Wisconsin.

The amount of lime in the different sections of Carrington loam is remarkably similar, the difference between the two drifts for any given level being no greater than that between duplicate determinations on the same sample. All calcium compounds at all readily soluble have evidently been leached out of this type to a depth greater than three feet.

The amount of lime in the form of carbonate was computed from the carbon clioxide content (Table $42, p t, 2)$. On the Carrington silt loam, only in the second and third foot-sections of the Late Wisconsin is any appreciable quantity shown. (On the Fargo silt loam the second foot-section on the Kansan is the only one to show a deficiency in this, while with the Carrington loam on both drifts the carbonate has been leached out to a depth greater than three feet.

By deducting the lime as carbonate from the total amount the quantity in the form of silicate is secured (Table +2, pt. 3). On the two prairie types, this decreases from the surface downward. On the forest tvpe, the Carrington loam, the first and fourth sections show like amounts, while the intervening two are alike and show somewhat smaller amounts. 
l whle 12.-Linte in the diffirent sections

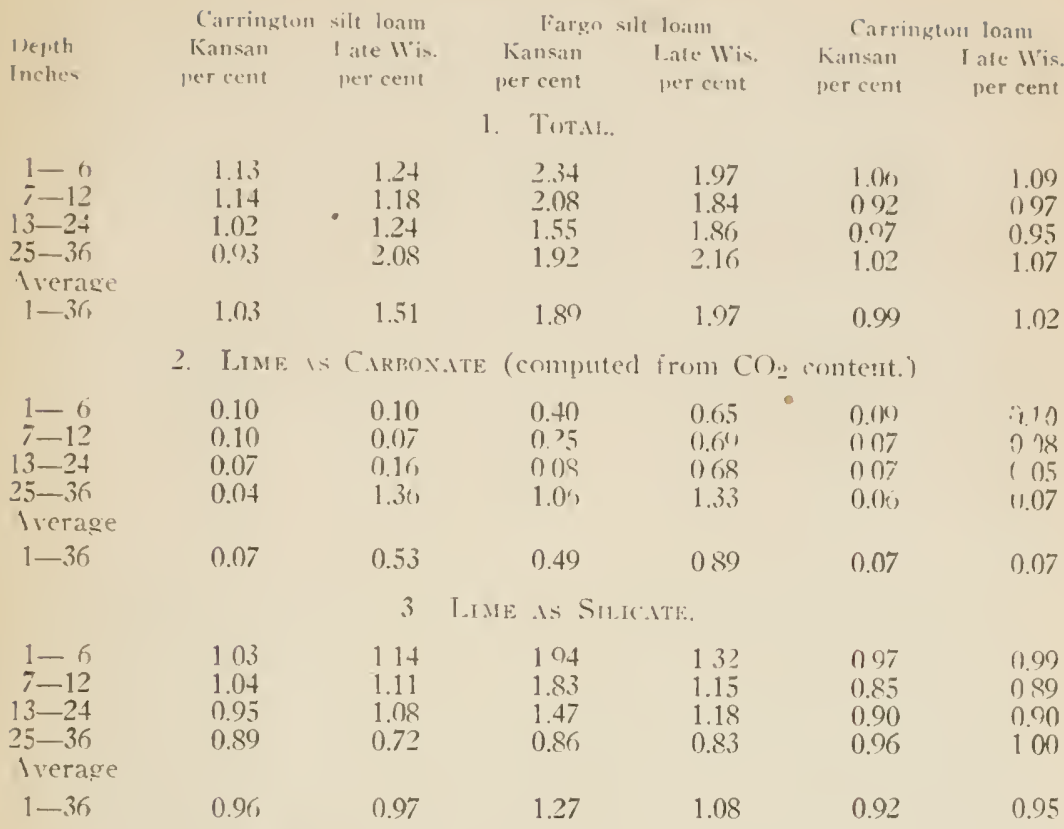

Discussion. With one exception the amount of total line in the surface section is sreater than in the second. Plant roots feeding in the lower levels carry this constituent into the acrial parts, which, on death and decar, leave behind in the surface layer this translocated lime.

On the Kansan the two Carrington series have lost the more readily soluble lime compounds to a denth of more than three feet. The Carrington silt loam on the Late Wisconsin still retains a considerable amount in the third foot-section, but with the Carrington loam the leaching has been as extensive as on the Kansan.

The poorly drained condition of the Fargo silt loam has prevented anv serious leaching on this tyoe. This is well illustrated by table 42. part 2. which shows every section well supplierl with carbonate with the exception of the second foot on the Kansan.

On the Kansan line in the form of carlonate bas been leached out to a depth greater than three feet with both the Carrington silt loan and the Carrington loam. On the Jate Visconsin the same is true for the latter type. but there is still an appreciable quantity in the third foot-section of the former.

On each trpe the averace amount of lime as silicate is very similar on hoth drifts with the exception of the Fareo silt loam, where it is slightly the higher on the Kansan. There is a general decrease in the amount of this from the surface downard on the prairie tvpes, while on the forest type there is but little variation in its vertical distribution. 


\section{Magnesia.}

There is very little difference between the amounts of magnesia (Table 43) found on the two drifts on any given type. The largest amount is found, as in the case of lime, on the Fargo silt loam, the average being, respectively, 1.25 per cent for the Kansan and 1.27 per cent on the Iate Wisconsin. The averages for the Carrington loam are slightly lower than those for the Carrington silt, loam, which are 0.87 per cent and 0.94 per cent, respectively, for the two drifts.

Table +5--Magnesia in the different sections.

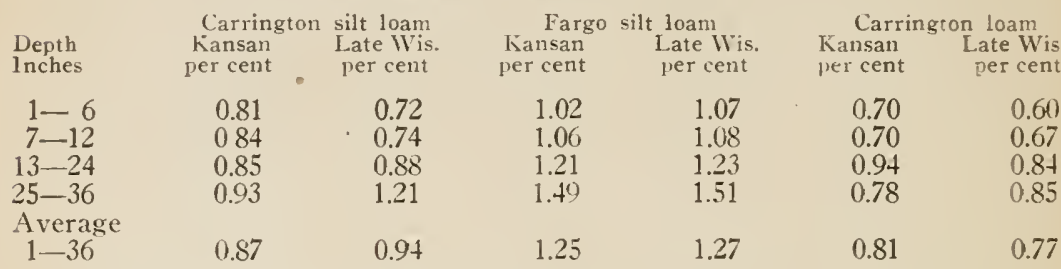

The ratio of total lime to magnesia (Table 44 , pt. 1 ) falls between 1.0 and 1.8 , averaging 1.4 for the three-foot section on all types. It is very similar for each type on both drifts, the greatest difference being shown on the Carrington silt loam, where, on the Kansan, it is 1.2 as compared with 1.5 on the Late $W$ isconsin. The optimum ratio varies with different plants (26), but in general the lime must equal or exceed the magnesia if the most satisfactory cultural results are to be obtained $(24$, p. 33$)$.

Table 14.-Relation of lime to magnesia in the different sections.

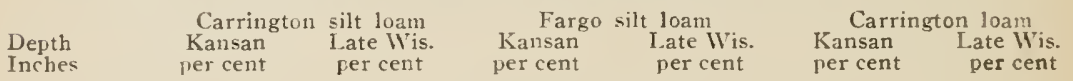

1. Ratio of Tot Il Lime to Magnesia.

$\begin{array}{ccccccc}1-6 & 1.4 & 1.7 & 2.3 & 1.8 & 1.5 & 1.8 \\ 7-12 & 1.3 & 1.6 & 2.0 & 1.7 & 1.3 & 1.4 \\ 13-24 & 1.2 & 1.4 & 1.3 & 1.5 & 1.0 & 1.1 \\ 25-36 & 1.0 & 1.6 & 1.3 & 1.4 & 1.3 & 1.3 \\ \begin{array}{c}\text { Average } \\ 1-36\end{array} & 1.2 & 1.5 & 1.6 & 1.6 & 1.2 & 1.3\end{array}$

2. Ratio of Lime as Silicate to Magnesia.

\begin{tabular}{|c|c|c|c|c|c|}
\hline $1-6$ & 1.2 & 1.5 & 1.9 & 1.2 & 1.4 \\
\hline $7-12$ & 1.2 & 1.5 & 1.7 & 1.0 & 1.2 \\
\hline $13-24$ & 1.1 & 1.2 & 1.2 & 0.9 & 1.0 \\
\hline $25-36$ & 0.9 & 0.6 & 0.5 & 0.5 & 1.2 \\
\hline $\begin{array}{l}\text { Average } \\
1-36\end{array}$ & 1.1 & 1. & 1.2 & 0.8 & 12 \\
\hline
\end{tabular}

On both prairie types the ratio of the portion of the lime in the form of silicate to magnesia (Table 44, pt. 2) decreases from the surface downward, as was the case with the amounts of lime in the form of silicate on these, while on the forest type it decreases through the first three sections, rising slightly again in the third foot. On both drifts the average ratio for each type is very similar with the exception of the Fargo silt loam, where that for the Kansas is the higher. 
Discussion. The amounts of mannesia found on the two drifts are very similar, the averages fur the three foot section on the Kansan and the Late Wisconsin, respectively, heing 0.98 per cent and 0.99 per cent. Considerable variation from type to type is shown, the Fargo silt loam carrying the most and the Carrington loam the least.

The ratio of total lime to magnesia is slightly the higher on the Late Wisconsin, this being due to its higher proportion of the former constituent.

The arerage ratio of lime as silicate to magnesia is very similar on both drifts with the exception of that for the farou silt loam on the Late Wisconsin, where it is somewhat the lower. The maximum ratio in every instance is found in the surface section while the minimum is found in the third foot, except on the Carrington loam, where it appears in the second foot-section.

\section{Phosphoric Acid.}

The phosphoric acid (Tables 45 to 48 ) was determined in all the field samples by the modification of IVashington's method described above (p. 41). Averages from these give the data for the drift samples (Table 49).

Carrington Silt Loam. On this type (Table 45) there is shown, in general, a decrease from the surface downward, a distribution characteristic of prairie soils (3). The amount found on the Kansan is slightly higher than that on the Late IVisconsin, the general average for the former being 0.165 per cent compared with 0.141 for the latter. The distribution from field to field is very regular.

Twble 45-Phosphoric acid in the different sections from the fire fields on Carrington silt loam.

\begin{tabular}{|c|c|c|c|c|c|c|}
\hline $\begin{array}{l}\text { Depth } \\
\text { Inches }\end{array}$ & $\begin{array}{c}\text { Field } \\
\text { I } \\
\text { per cent }\end{array}$ & $\begin{array}{l}\text { Field } \\
\text { II } \\
\text { per cent }\end{array}$ & $\begin{array}{l}\text { Field } \\
\text { III } \\
\text { percent }\end{array}$ & $\begin{array}{l}\text { Field } \\
\text { IV } \\
\text { per cent }\end{array}$ & $\underset{\text { per cent }}{\text { Field }}$ & $\begin{array}{l}\text { Average fo } \\
5 \text { fields } \\
\text { per cent }\end{array}$ \\
\hline & & & 1. KANSix. & & & \\
\hline $1-6$ & 0.245 & 0.220 & 0.258 & 0.214 & 0.204 & 0.228 \\
\hline $7-12$ & 0.200 & 0.223 & 0.220 & 0.191 & 0.188 & 0.204 \\
\hline $13-24$ & 0.159 & 0.165 & 0.147 & 0.137 & 0.147 & 0.151 \\
\hline $25-36$ & 0.140 & 0.143 & 0.127 & 0.102 & 0.134 & 0.129 \\
\hline $\begin{array}{c}\text { Average } \\
1-36\end{array}$ & 0.174 & 0.176 & 0.171 & 0.147 & 0.159 & 0.165 \\
\hline
\end{tabular}

2. Late Wisconsin.

$\begin{array}{lllllll}\text { 1-6 } & 0.204 & 0.182 & 0.172 & 0.175 & 0.178 & 0.182 \\ \text { 7-12 } & 0.210 & 0.151 & 0.153 & 0.172 & 0.156 & 0.168 \\ \text { 13-24 } & 0.156 & 0.108 & 0.144 & 0.147 & 0.118 & 0.135 \\ \text { 25-36 } & 0.102 & 0.104 & 0.121 & 0.143 & 0.096 & 0.113 \\ \begin{array}{c}\text { Average } \\ \text { 1-36 }\end{array} & 0.155 & 0.126 & 0.142 & 0.154 & 0.127 & 0.141\end{array}$

Fargo Silt Loam. While somewhat larger amounts of phosphoric acid are found in the soils of this type (Table 46), the same observations as to its distribution apply. The difference in the amounts found on the two drifts are, however, much sreater, the average for the 
Kansan being 0.214 per cent compared with 0.156 per cent for the Late Wisconisin. The former shows the higher content in all four levels. It is to be noted that the decrease in the amounts found in the third fontsection (n the Kansan is not nearly so great as on the younger drift.

Table 46.-Phosphoric acid in the different sections from the five fields on Fargo silt loam.

\begin{tabular}{|c|c|c|c|c|c|c|}
\hline $\begin{array}{l}\text { Depth } \\
\text { Inches }\end{array}$ & $\begin{array}{c}\text { Field } \\
\text { I } \\
\text { per cent }\end{array}$ & $\begin{array}{l}\text { Field } \\
\text { II } \\
\text { per cent }\end{array}$ & $\begin{array}{c}\text { Field } \\
\text { III } \\
\text { per cent }\end{array}$ & $\begin{array}{l}\text { Field } \\
\text { IV } \\
\text { per cent }\end{array}$ & $\underset{\substack{V \\
\text { per cent }}}{\text { Field }}$ & $\begin{array}{c}\text { Average fo } \\
5 \text { fields } \\
\text { per cent }\end{array}$ \\
\hline \multicolumn{7}{|c|}{ 1. KANSAN. } \\
\hline $1-6$ & 0.290 & & 0.255 & 0.363 & 0.338 & 0.311 \\
\hline $7-12$ & 0.248 & 0.223 & 0.207 & 0.264 & 0.283 & 0.243 \\
\hline $13-24$ & 0.169 & 0.182 & 0.162 & 0.207 & 0.210 & 0.186 \\
\hline $25-36$ & 0.179 & 0.172 & 0.168 & 0.201 & 0.175 & 0.179 \\
\hline $\begin{array}{l}\text { Average } \\
1-36\end{array}$ & 0.206 & & 0.187 & 0.240 & 0.232 & 0.214 \\
\hline \multicolumn{7}{|c|}{ 2. LAte Wisconsin. } \\
\hline $1-6$ & 0.239 & 0.229 & 0.219 & 0.220 & 0.216 & 0.225 \\
\hline $7-12$ & 0.185 & 0.156 & 0.213 & 0.179 & 0.185 & 0.184 \\
\hline $13-24$ & 0.146 & 0.172 & 0.188 & 0.134 & 0.115 & 0.151 \\
\hline $25-36$ & 0.118 & 0.099 & 0.121 & 0.112 & 0.111 & 0.112 \\
\hline $\begin{array}{c}\text { Average: } \\
1-36\end{array}$ & 0.159 & 0.154 & 0.175 & 0.148 & 0.142 & 0.156 \\
\hline
\end{tabular}

Carrington Loam. In the soils on this type (Table 47) neither the distribution from the surface downward nor that from field to field is as regular as was the case on the two prairic types. The averages for the five fields on the two drifts show a general decrease from the surface downward, although on the Late WVisconsin they are, below the first 6-inch section, practically the same. The general average for the Kansan is slightly the higher, being 0.177 per cent as compared with 0.151 per cent for the Late Wisconsin.

Tabl: 47.-Phosphoric acid in the different sections from the five fields on Carringto $n$ lcam.

Depth

Inches

$$
\begin{gathered}
\text { Field } \\
\text { I } \\
\text { ver cent }
\end{gathered}
$$

$1-6$
$7-12$

$13-24$

25-36

Average

$1-36$

$1-6$
$7-12$

$13-24$

$25-36$

Average

$1-36$
0.236

0.182

0.150

0.124

0.161

0.213

0.178

0.162

0.162

0.17 .3

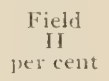

0.216

0.160

0.162

0.159

0.170

2. Late Wisconsin.

$\begin{array}{llll}0.175 & 0.207 & 0.162 & 0.213 \\ 0.140 & 0.159 & 0.115 & 0.143 \\ 0.147 & 0.147 & 0.131 & 0.128 \\ 0.162 & 0.110 & 0.131 & 0.137 \\ & & & \\ 0.155 & 0.147 & 0.133 & 0.148\end{array}$

0.194

0.147

0.143

0.140

0.151 


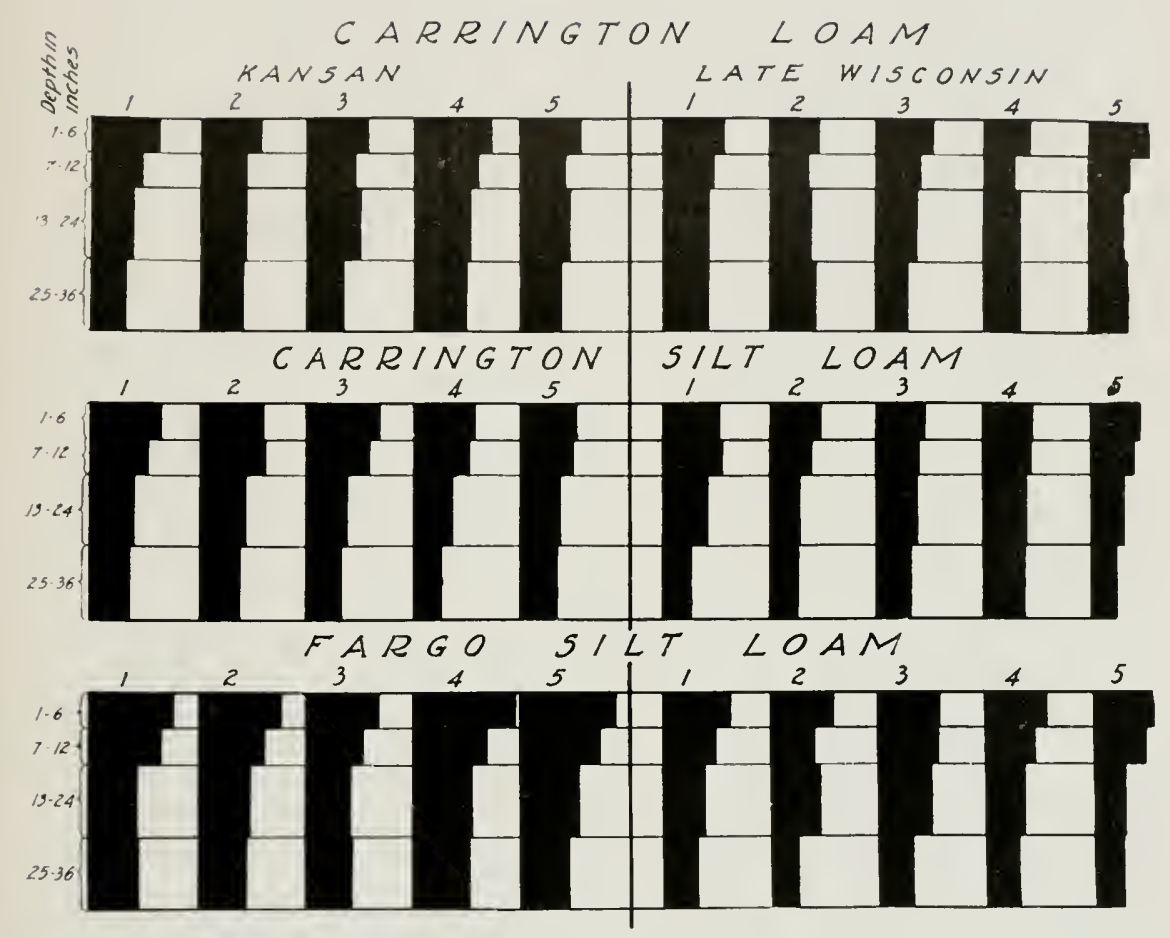

Fig. 5.-Diagram showing the distrilution of phosphore acid on the different types on both drifts. 
PI. ITE: VI

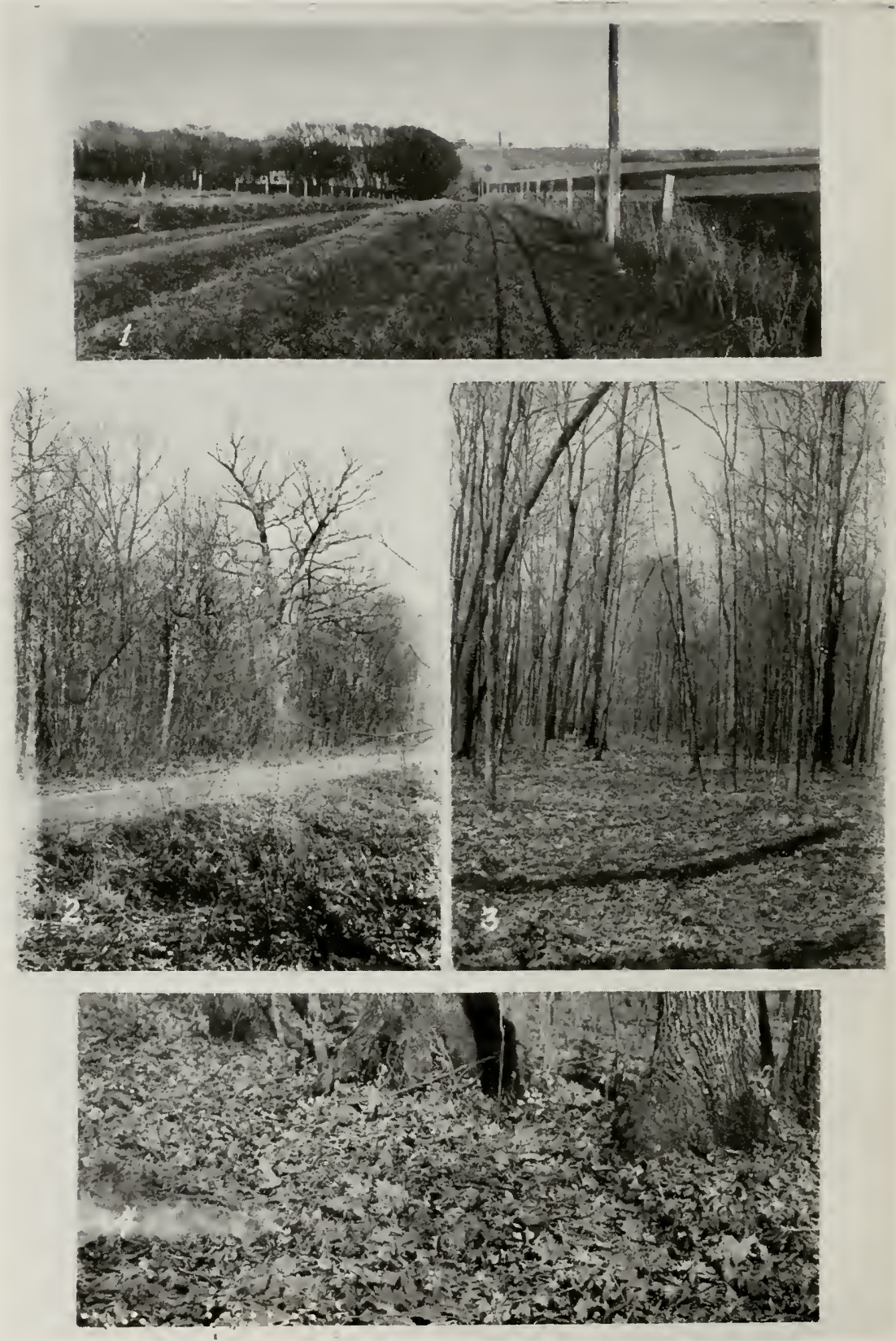

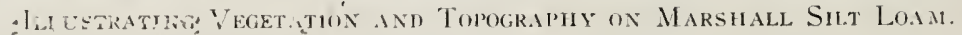

$\because 1$. Ticla $V$, a rodulde strip remnant of the original prairie.

2-3. Fields I and HII, still in forest.

4. View of forest floor in above fields. 
Marshall Sill l.oum. The phosphoric acid in soils from the forested fields, I, II and III (Table 48) shows the sance irregularity at that on the other forest type, the Carrington loam. The cleared fields, IV and $V$, are in seneral more like those on the pratirie types, the amounts being considerably higher than those found on the other three. As pointed out above (p. 2t), the thickness of loesial deposit on the three forested fields is not great, the till being cncountered in the third foct on two of them so that it is not improbable that these have been so:newhat modified. The cleared fields, on the other hand, appear tu be more typical of this type, the thickness of the deposit here being sulficient to remove any chance of inter-mixing with boulder clay from below.

Table 18. - Phosphoric acid from the different sections: from the five fields on Marshall silt loam.

$\begin{array}{ccccccc}\begin{array}{c}\text { Depth } \\ \text { Inches }\end{array} & \begin{array}{c}\text { I'ield } \\ \text { I } \\ \text { percert }\end{array} & \begin{array}{c}\text { Ficld } \\ \text { II } \\ \text { percent }\end{array} & \begin{array}{c}\text { Field } \\ \text { III } \\ \text { per cent }\end{array} & \begin{array}{c}\text { Field } \\ \text { IV } \\ \text { per cent }\end{array} & \begin{array}{c}\text { Field } \\ \text { V } \\ \text { per cent }\end{array} & \begin{array}{c}\text { Average for } \\ 5 \text { fields } \\ \text { percent }\end{array} \\ 1-6 & 11.167 & 0.143 & 0.172 & 0.226 & 0.223 & 0.186 \\ 7-12 & 11.153 & 0.146 & 0.147 & 0.207 & 0.207 & 0.172 \\ 13-24 & 11.124 & 0.124 & 0.153 & 0.162 & 0.178 & 0.148 \\ 25-36 & 11.114 & 0.159 & 0.153 & 0.172 & 0.166 & 0.153 \\ \text { Average } & & & & & & \\ 1-36 & 11.132 & 0.142 & 0.155 & 0.183 & 0.186 & 0.160\end{array}$

Discussi)n. The averages for the five fields from the different types on the rwo drifts are shown in table 49 . The amounts found on the Kansan, on each type and in every field, are greater than those on the Late Wisconsin. The vertical distribution on the prairie types. viz., the Carrington silt loam and the Fargo silt loam, shows a steady decreast: from the surface downward while that on the forest types is irregular.

Table 19.--Phosphoric acid in the different sections. The data are the arerage's for the fire ficlds reported in tables 45 to 18 inclusice.

\begin{tabular}{|c|c|c|c|c|c|c|c|}
\hline \multirow[b]{2}{*}{$\begin{array}{l}\text { Depth } \\
\text { Inches }\end{array}$} & \multicolumn{2}{|c|}{ Carrington silt loam } & \multicolumn{2}{|c|}{ Fargo silt loam } & \multicolumn{2}{|c|}{ Carrington loam } & \multirow{2}{*}{$\begin{array}{l}\text { Marshall } \\
\text { silt loam } \\
\text { Kansan } \\
\text { per cent }\end{array}$} \\
\hline & $\begin{array}{l}\text { Karsan } \\
\text { per cent }\end{array}$ & $\begin{array}{l}\text { Late Wis. } \\
\text { per cent }\end{array}$ & $\begin{array}{l}\text { Kansan } \\
\text { per cent }\end{array}$ & $\begin{array}{l}\text { 1.ate Wis. } \\
\text { per cent }\end{array}$ & $\begin{array}{l}\text { Kansan } \\
\text { per cent }\end{array}$ & $\begin{array}{l}\text { Late Wis. } \\
\text { per cent }\end{array}$ & \\
\hline $1-6$ & 0.228 & 0.182 & 0.311 & 0.225 & 0.233 & 0.194 & 0.180 \\
\hline $7-12$ & 0204 & 0.16 & 0.243 & 0.1 & 0.180 & 0.147 & 0.172 \\
\hline $13-24$ & 0151 & 0.135 & 0.186 & 0.151 & 0.176 & $0.1+3$ & 0.148 \\
\hline $25-36$ & 0.129 & 0.113 & 0.179 & 0.112 & 0.150 & 0.140 & 0.15 .3 \\
\hline Avera & & & & & & & \\
\hline $1-36$ & 0.165 & 0.141 & 0.214 & 0.156 & 0.177 & 0.151 & $0.160)$ \\
\hline
\end{tabular}




\section{Potash.}

The potash (Table 50 ) is fairly uniform for each type on the two drifts, the averages for the three-foot section, with the exception of those for the Carrington loam, being practically the same. On the I.ate Wisconsin the latter type shows slightly higher amounts, averaging 1.88 per cent compared with 1.74 on the older drift. However, if the amounts found in the fifteen fields on each drift are averaged the percentage is the same in both cases, viz., 1.79.

\section{Table 50.-Potash in the differcnt scctions.}

\begin{tabular}{|c|c|c|c|c|c|c|}
\hline \multirow[b]{2}{*}{$\begin{array}{l}\text { I)eyth } \\
\text { Inche: }\end{array}$} & \multirow{2}{*}{\multicolumn{2}{|c|}{$\begin{array}{cc}\text { Carrington } & \text { silt loam } \\
\text { Kansall } & \text { Late Wirs. } \\
\text { per cent } & \text { per cent }\end{array}$}} & \multicolumn{2}{|c|}{ Fargo silt loam } & \multicolumn{2}{|c|}{ Carrington loam } \\
\hline & & & $\begin{array}{l}\text { Kansan } \\
\text { per cent }\end{array}$ & $\begin{array}{l}\text { Late Wis. } \\
\text { per cent }\end{array}$ & $\begin{array}{l}\text { Kansan } \\
\text { per cent }\end{array}$ & $\begin{array}{l}\text { Late Wis. } \\
\text { per cent }\end{array}$ \\
\hline $\begin{array}{l}1-6 \\
7-12 \\
13--24 \\
25-36\end{array}$ & $\begin{array}{l}1.76 \\
1.84 \\
1.90 \\
1.87\end{array}$ & $\begin{array}{l}1.66 \\
1.74 \\
1.86 \\
1.87\end{array}$ & $\begin{array}{l}1.57 \\
1.64 \\
1.83 \\
1.86\end{array}$ & $\begin{array}{l}1.60 \\
1.68 \\
1.71 \\
1.75\end{array}$ & $\begin{array}{l}1.72 \\
1.76 \\
1.82 \\
1.65\end{array}$ & $\begin{array}{l}1.86 \\
1.9 ; \\
1.16 \\
1.76\end{array}$ \\
\hline vera & & & & & & \\
\hline $1-36$ & 1.86 & 1.80 & 1.76 & 1.70 & 1.74 & 1.88 \\
\hline
\end{tabular}

The percentages found for the surface sections are, in every case, lower than those found for the second, while the amounts in the three lower sections, except those on the Carrington loam, are very similar. On the type just mentioned the third foot-section carries on both drifts a smaller amount than any of those above it.

\section{Soda.}

On the two Carrington series the soda (Table 51) is very uniform for both drifts, showing little variation either between the different sections or from the surface downward. With the Fargo silt loam the amounts are distinctly the higher on the Kansan, averaging 1.48 per cent as compared with 1.23 per cent for the younger drift. The widest range in distribution from the surface downward is shown by the same fields, where it varies from 1.31 per cent in the surface to 1.59 per cent in the third foot.

Table 5I.-Soda in the different scctions.

$\begin{array}{lccccrr}\begin{array}{l}\text { Depth } \\ \text { Inches }\end{array} & \begin{array}{c}\text { Carrington } \\ \text { Kansan } \\ \text { per cent }\end{array} & \begin{array}{c}\text { silt loam } \\ \text { Late Wis. } \\ \text { per cent }\end{array} & \begin{array}{c}\text { Kansan } \\ \text { per cent }\end{array} & \begin{array}{c}\text { silt loam } \\ \text { Late Wis. } \\ \text { per cent }\end{array} & \begin{array}{c}\text { Carrington loam } \\ \text { Kansan } \\ \text { per cent }\end{array} & \begin{array}{r}\text { Late Wis. } \\ \text { per cent }\end{array} \\ \begin{array}{l}1-6 \\ 7-12\end{array} & 1.26 & 1.39 & 1.31 & 1.18 & 1.46 & 1.41 \\ 13-24 & 1.36 & 1.35 & 1.48 & 1.29 & 1.42 & 1.42 \\ 25-36 & 1.37 & 1.33 & 1.45 & 1.27 & 1.38 & 1.40 \\ \text { Average } & 1.29 & 1.31 & 1.59 & 1.18 & 1.41 & 1.42 \\ 1-36 & 1.32 & 1.33 & 1.48 & 1.23 & 1.41 & 1.41\end{array}$




\section{ORGANIC CONSTITUENTS.}

\section{Volatile Matter.}

The volatile matter, which in the present instance includes the organic matter and water of constitution, is reported in table 52. There is very little difference in the amounts found on the two drifts when the comparison is made between the various sections on the two types of the Carrington series, lut a very wide one is observed when the surface 6-inch section of the Fargo silt loam is taken into consideration. On the Kansan this rises to 20.34 per cent as compared with 11.68 per cent on the Late Wisconsin.

Table 52.-Folutile matter in the different sections.

$\begin{array}{lccccrr}\begin{array}{l}\text { Depth } \\ \text { Inches }\end{array} & \begin{array}{c}\text { Carrington } \\ \text { Kansan } \\ \text { per cent }\end{array} & \begin{array}{c}\text { Late WVis. } \\ \text { per cent }\end{array} & \begin{array}{c}\text { Kansan } \\ \text { ler cent }\end{array} & \begin{array}{c}\text { Late Wis. } \\ \text { per cent }\end{array} & \begin{array}{c}\text { Cansang } \\ \text { ler cent }\end{array} & \begin{array}{r}\text { Late Wis, } \\ \text { per cent }\end{array} \\ 1-6 & 10.52 & 9.38 & 20.34 & 11.68 & 6.41 & 6.71 \\ 7-12 & 8.58 & 7.80 & 12.12 & 9.61 & 3.73 & 4.15 \\ 13-24 & 6.07 & 5.34 & 5.41 & 6.43 & 3.32 & 3.77 \\ 25-36 & 3.73 & 2.99 & 2.19 & 4.40 & 2.66 & 2.89 \\ \text { Average } & & & & & & \\ 1-36 & 6.45 & 5.64 & 7.94 & 7.16 & 3.68 & 4.03\end{array}$

The course of the streams before the Late IVisconsin glaciation was in a general southwesterly direction, but the ice, and later the drift material left behind, blocked the previously existing drainage chanuels and forced the water to find outlets to the southeast. liefore these new channels were fully developed the drainage was very incomplete and undoubtedly large areas were covered by standing water part of the season. The surface material carried by the water from the surrounding highlands was thus deposited on the lowlands. Organic material accumulated through the growth of dense lowland vegetation and the deposition of the remains of this. Little or no peat was formed on this drift.

On the Late Wisconsin the poorly drained areas were not as numerous as on the older formation and such as existed were more in the form of "pot holes" in which the conditions for the formation of peat were favorable, so that in most instances we have the Fargo silt loam as a narrow band between the low lying peat areas and the upland soil. Further, the high land did not have the black surface soil which remained on the unglaciated Kansan from the as yet munamed interglacial interval preceding the I ate Wisconsin, and hence, the eroded material accumulated in the lower lying areas was not so rich in organic matter. 


\section{Organic Carbon.}

The oryanic carbon was determined by combustion with copper oxide in a current of oxygen, the sample of soil having first been digested with phosphoric acid solution and evaporated to dryness.

The amounts of organic carbon (Table 53) on both types of the series differ little from drift to drift. The Carrington loam carries much less than the silt loam. The Marshall silt loam closely resembles the former.

Table 53.-Organic Carbon in the differcul sections.

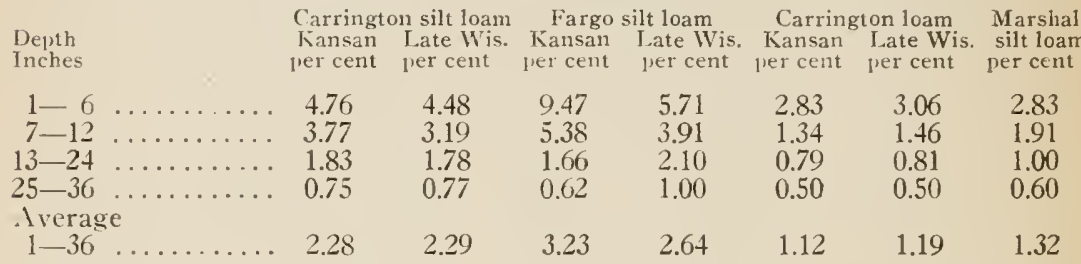

With the Fargo silt loam the upper two sections are much richer in organic carbon on the Kansan than on the Late Visconsin. This is to be attributed to the Late Wisconsin glaciation obstructing the drainage on the Kansan with resulting increased accumulation of eroded surface soil dereloped during pre-Wisconsin time. The organic carbon in the second and third foot sections on this type shows much less difference, it being slightly the higher on the Late $W$ isconsin.

\section{Nitrogen.}

Nitrogen was rletermined on both sets of samples from each field, using the Gunning modification of the Kjeldahl method. The normal variation in upland fields shows a decrease from the surface downward, this being especially regular in the case of prairie fields (2, p. 219).

Carrington Silt Loam. Considerable variation within the same field and from field to field is shown on both drifts (Table 54). The average amounts on the two drifts are very similar.

It is to be olsserved that in the second and third foot-sections the differences between the two sets from the same field and between the field samples are as great as, if not greater than, in the sections of the surface foot where a difference in compactness and accordingly a difference in density (2. p. 219) might account for it.

Fargo Silt Loam. As with the Carrington silt loam, the nitrogen varies considerably from field to field and within a few of the individual fields (Table 55). An extraordinary range is shown in Field IV on the Kansan, where it varies from slightly over 1.0 per cent in the surface to .028 per cent in the subsoil. 


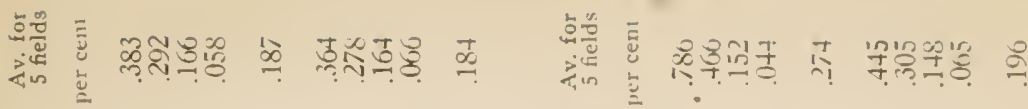

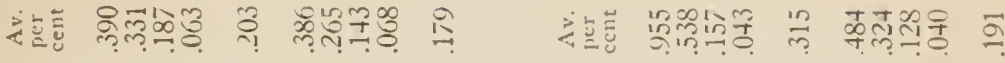

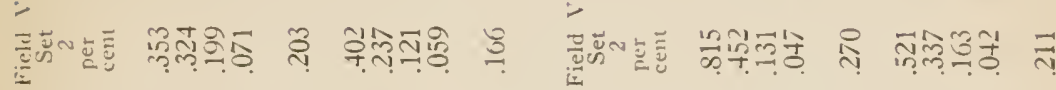

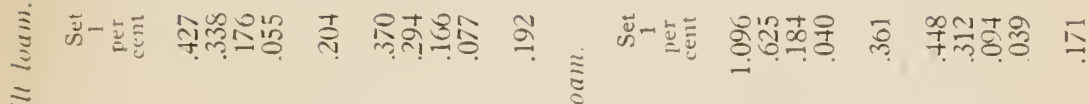
宊

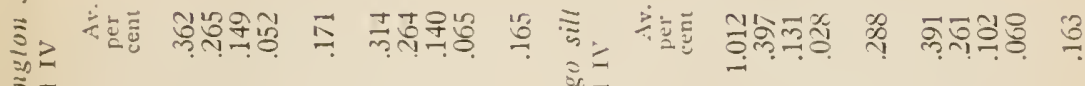

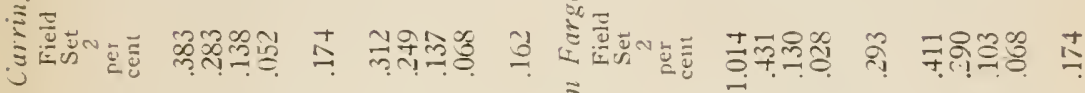

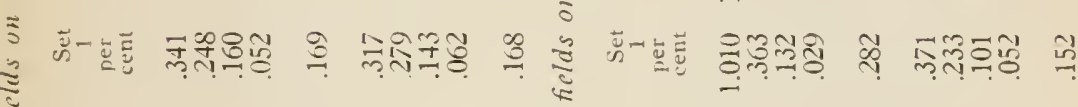

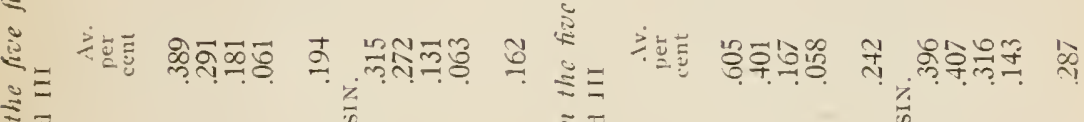

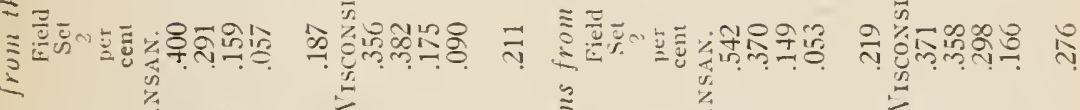

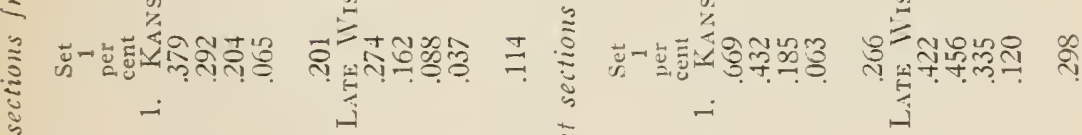

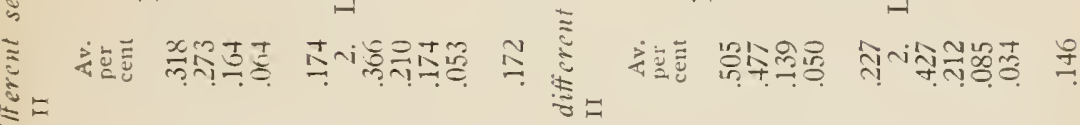

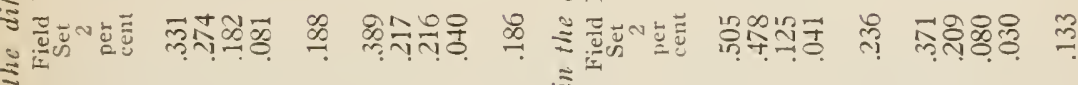

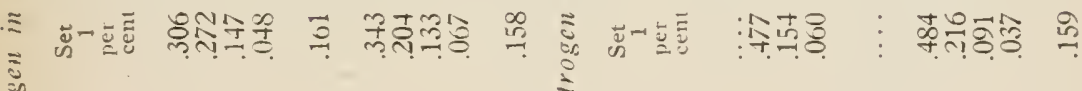

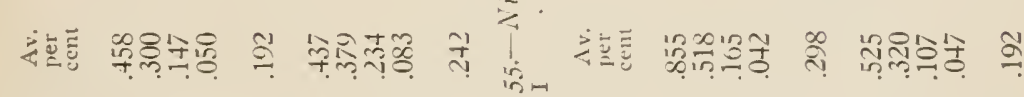

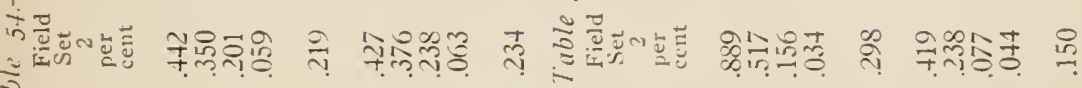

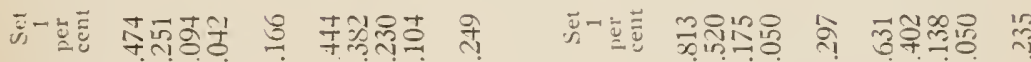

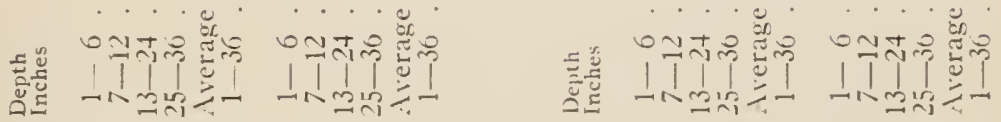




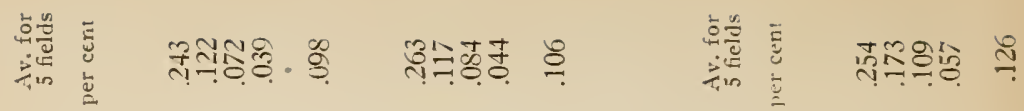

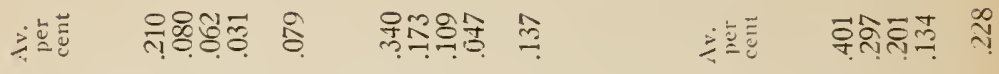

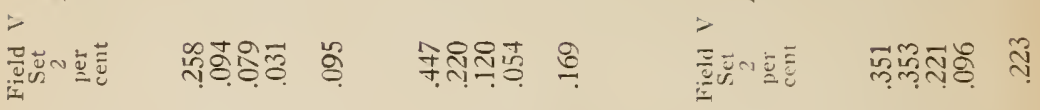

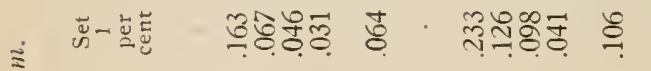

-

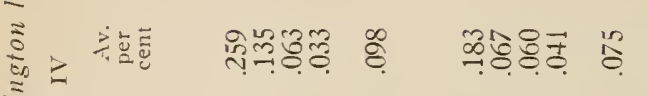

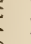

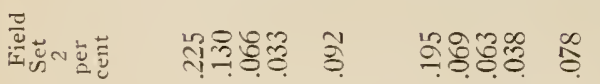
곡

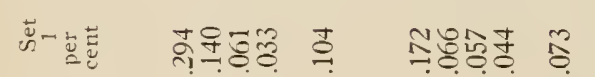

है

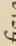
气

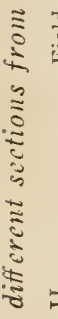

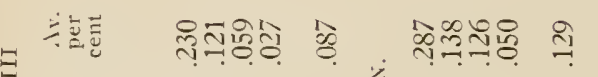
政

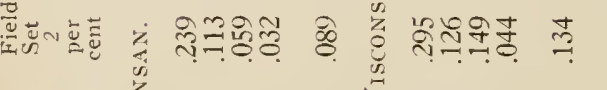

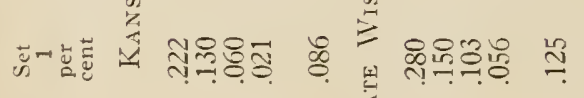

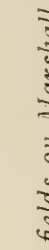

\section{पर}

-

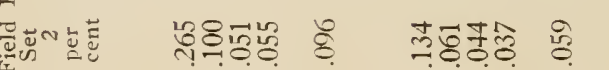

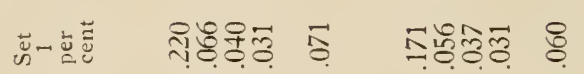

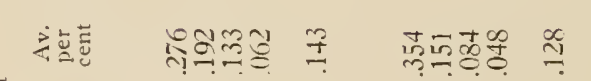
z)

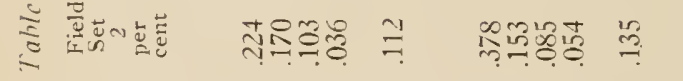

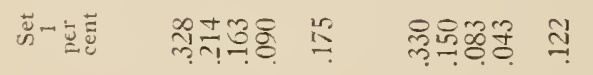

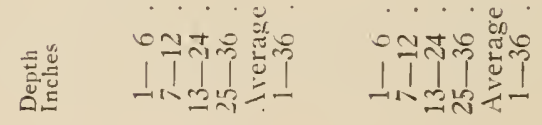




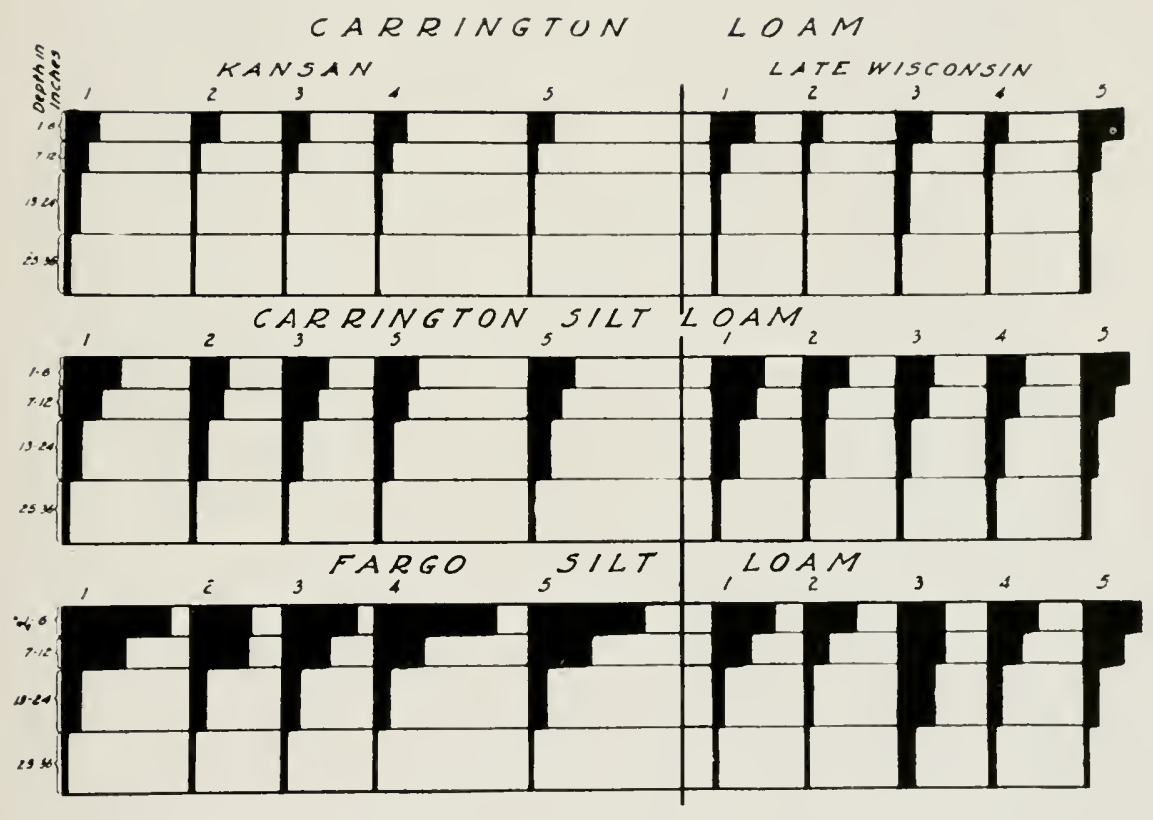

Fig. 6.-Diagram showing the distribntion of nitrogen on the different tyes on both drifts. 

There is a wide difference in the amounts of nitrosen found in the surface foot on the two drifts, those on the Kansan being, on the average, 76 per cent the higher in the surface six inches and 52 per cent the higher in the second section. The conditions mentioned above (p. 53) under which the soils of this type were developed furmish an explanation for this difference, the accumulation of organic matter and nitrogen being parallel.

The average amount of nitrogen found in the second and third foot-sections on the two drifts are, on the other hand, yuite similar.

Carrington Ioam. The amounts of nitrogen found in a forest type are naturally not as high as those found on the prairie types. The variation (Table 56) within the same field and from ficld to field, as well as the distribution from the surface downward, are much the same. There is little difference between the averages for the two drifts.

Marshall Silt Loam. The three forested fields, I. II and III, show little variation within the same field, but a wider one from field to field (Table 57). In the amounts present these resemble the fields on the Carrington loam, a forest type.

The cleared fields, IV and $V^{\top}$, resemble the prairie types in both the amounts of nitrogen and its distribution.

Discussion. The averages for the five fields on the different types are shown in table 58. Both the Carrington silt loam and the Carrington loam are very similar on the two drifts. The latter shows the lowest percentage of all four types, but this is to be explained by the fact that the areas sampled were all forested while prairie conditions prevailed on the other types, with the exception of three fields on the Marshall silt loam.

Table 58.-Nitrogen in the different sections. The data are anerages for the fiv'e ficlds reported in tables 5 to 57 inclusiz'c.

\begin{tabular}{|c|c|c|c|c|c|c|c|}
\hline \multirow[b]{2}{*}{$\begin{array}{l}\text { Depth } \\
\text { Inches }\end{array}$} & \multicolumn{2}{|c|}{ Carrington silt loam } & \multicolumn{2}{|c|}{ Fargo silt loam } & \multicolumn{2}{|c|}{ Carrington loam } & \multirow{2}{*}{$\begin{array}{l}\text { Marshall } \\
\text { silt loam } \\
\text { per cent }\end{array}$} \\
\hline & $\begin{array}{c}\text { Kansan } \\
\text { percent }\end{array}$ & $\begin{array}{l}\text { I.ate Wis. } \\
\text { per cent }\end{array}$ & $\begin{array}{r}\text { Kansan } \\
\text { per cent }\end{array}$ & $\begin{array}{l}\text { Late Wis. } \\
\text { per cent }\end{array}$ & $\begin{array}{l}\text { Kansan } \\
\text { jer cent }\end{array}$ & $\begin{array}{l}\text { Late Wis. } \\
\text { per cent }\end{array}$ & \\
\hline $1-6$ & .383 & .364 & .786 & .445 & .243 & .263 & .254 \\
\hline $7-12$ & .292 & .278 & .466 & .305 & .122 & .117 & .173 \\
\hline $13-24$ & .166 & .164 & .152 & .148 & .072 & .084 & .109 \\
\hline $25-36$ & .058 & .066 & .044 & .065 & .039 & .044 & .057 \\
\hline $\begin{array}{c}\text { Average } \\
1-36\end{array}$ & .187 & .184 & .274 & .196 & .098 & .106 & .126 \\
\hline
\end{tabular}

With the Fargo silt loam the two mpyer sections are much richer in nitrogen on the Kansan than on the Iate Wisconsin, the former being 76 per cent higher in the first 6 -inch section and 52 per cent in the second. This corresponds to the organic carbon (Table 5.3). The averages for the second and third foot-sections on this type are very similar.

The average for the three feet on the Marshall silt loam is quite similar to both of those on the Carrington loam, the difference beins: due to the relatively large amounts found in the two cleared fields on the former. 


\section{E. COLOR.}

A color comparison was made of all the samples, inclating those of both sets from each field. For this purpose a 25-gram portion of each soil passed through a $2 \mathrm{~mm}$. sieve, was placed in a porcelain dish of $100 \mathrm{cc}$. capacity, moistened and allowed to temper for an hour. Then all the moistened samples were arranged in order of color, the darkest being placed at one end and the lightest colored at the other.

It was found possible to differentiate the soils into eight groups (Tables 59 to 62), the shades of color in which were fairly distinct. The graduation from one group into another, however, was not abrupt. nor did every member of any of the groups possess exactly the same shade as all the others. While eight shades of color were distinguishable, there were only three basic colors, viz., black, white and red. The members of group 1, the darkest, and of group 2 were black to black with a brownish tint, those of group 3 brownish black to dark brown, of 4 dark brown, of 5 dark reddish brown, of 6 light reddish brown, of 7 brownish red, and of 8 brownish gray to light gray. The color subsoils, as has recently been pointed out $(1, \mathrm{p} .253)$. is not dependent upon the amount of organic matter, being due in large part to other coloring material. The degree of oxidation of the iron affects the color as illustrated by groups 7 and 8 , which have relatively the same intensity of color but the former has the more pronounced reddish shade because of a higher degree of oxidation of the iron.

Carrington Silt Loam. Considerable variation in color was found between sets within the same field as well as from field to field, this being as great on one drift as on the other (Table 59).

On the Late Wisconsin the soils in the first 6-inch section have. in general, a relatively darker color than those of the corresponding level on the older formation. There is quite a marked difference in the shade of color between the soils from the third foot level on the two drifts, those on the Kansan having a distinctly reddish tint, while on the younger drift browns, grays, and gravish browns predominate. This would indicate that the oxidation of the iron has not proceeded as far on the latter. The averages for the five fields, with the exception of the first six inches, are the same.

Fargo Silt Loam. With the exception of Fields I and II on the Late Wisconsin, there is little variation between the two sets within the same field (Table 60 ). The average for the three foot sections on the Kansan are the same, while a wider variation is shown on the Late Wisconsin. On the latter the color of the soils in the second 


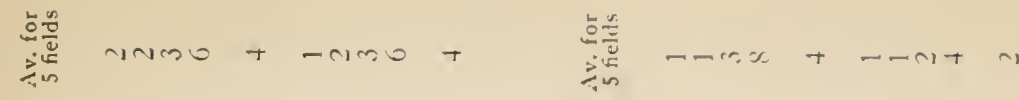
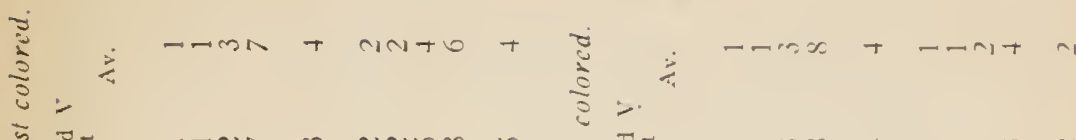

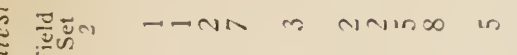

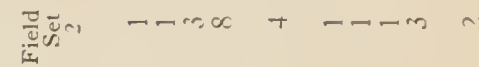

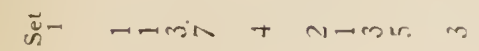

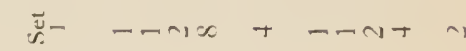

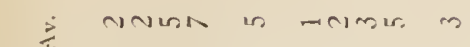

$=-\infty+\infty+\infty+\infty$

三

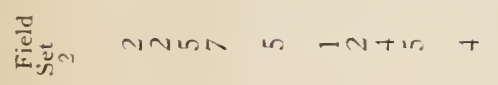

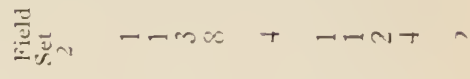

$\cong$

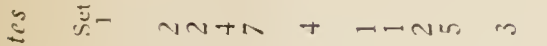

$\breve{y}--m+--N+\cdots$

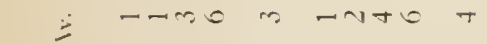

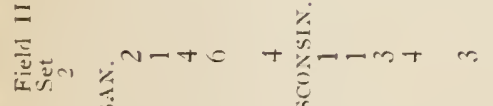

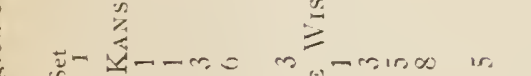

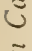

亏

$\frac{3}{3}$

$\cong$

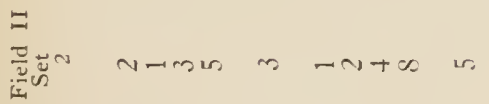

ז̈- vesm $+-m+\infty$ is.

$\frac{2}{3}$

$\therefore$ NNmo + Nat 1

ชั

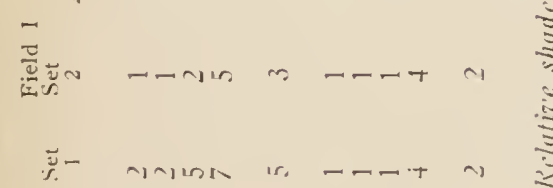

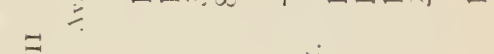

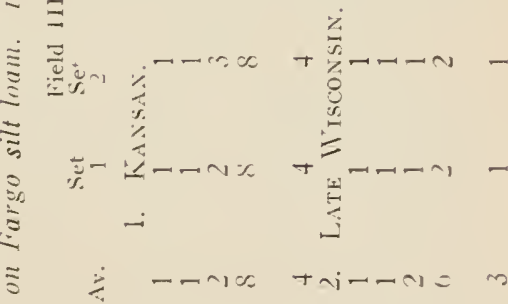

$\stackrel{3}{3}$

$\cong$

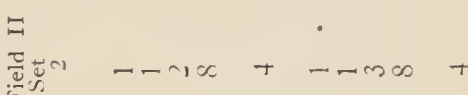

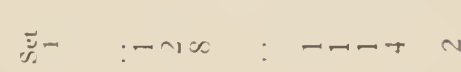

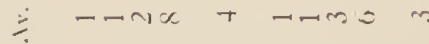

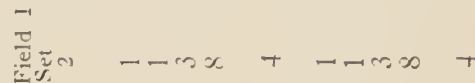

รั- - -

in

$\stackrel{2}{3}$

$\vdots \vdots \vdots \vdots \vdots \vdots \vdots \vdots \vdots \vdots$

$\stackrel{\Xi}{\Xi}$

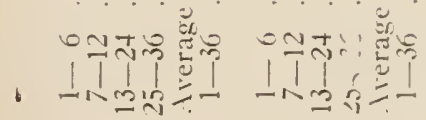

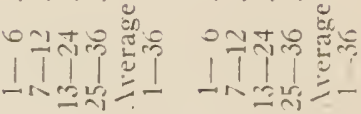




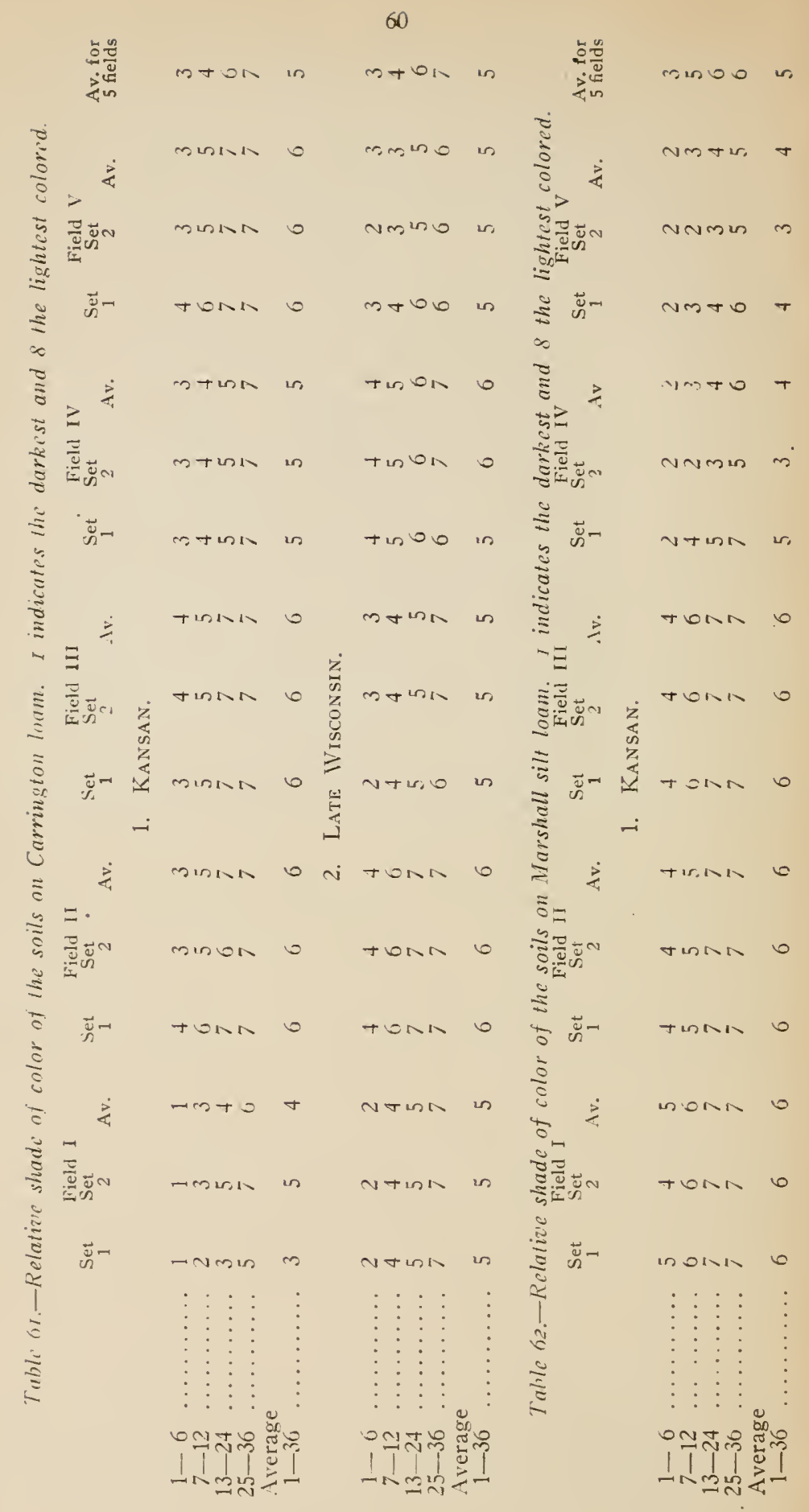


and third foot-sections is relatively darker. With this type the grays characterize the third foot-sections on the Kansan, being absent from a majority of the fields on the Late $\mathrm{W}$ isconsin, a condition just the opposite to what prevailed on the Carrington silt loam. This nav be attributed to the obstructed drainage, mentioned above, on the older drift, the water table being relatively close to the surface, this excluding the air and preventing any considerable oxidation of the iron componnds, while on the younger formation this type is confined to more or less narrow bands around the lower lying areas and consequently does not have the water table as near to the surface.

Carrington Loam. The remarkable similarity between the two drifts characteristic of the soils of this type already mentioned extends to the color also (Table 61). With the exception of Field I on the Kansan, there is little variation within the individual fields, either from field to field, or from drift to drift.

Marshall Silt Loam. There is little variation in color between the soils from the two sets within the same field (Table 62) but, as with the chemical composition. there is a marked difference between the three forested fields, I, II and III, and the two cleared ones, IV and $\mathrm{V}$. On the latter the effect of the accumulation of organic matter has reached as far as the third foot, causing a darker shade than if found in the corresponding level in the forested fields.

Discussion. The averages for the five fields on the different types on the two drifts are shown in Table 63. There is little difference in intensity of color between the soils of any one type on either drift, and none at all. if we except the surface 6 inches, on the Carrington silt loam and the second and third foot-sections on the Fargo silt loam. In the case of these exceptions the color of the soils on the Late Wisconsin is darker, indicating a condition just opposite to that reported by Burke and Kolbe (11, p. 21), who presumably refer to the surface soil when they state that "the Kansan drift has senerally" a darker color than the Wisconsin."

Table 63.-Relative shade of color. The data are the arierages for the fir'e fields reported in tables 59 to 62 inclusize.

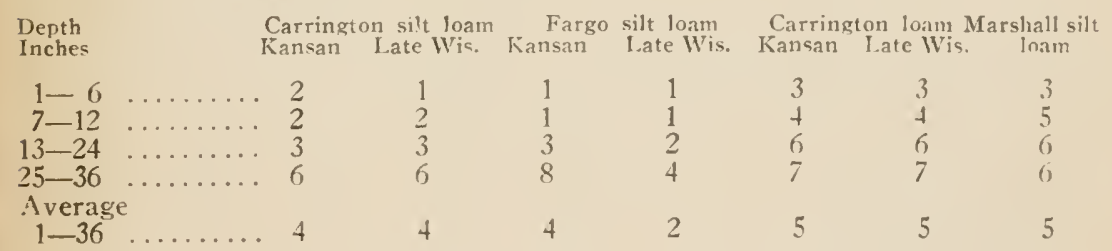




\section{CLASSIFICATION OF RICE COUNTY TYPES ACCORDING} TO THE RUSSIAN SYSTEM.

Having reported in detail the composition and properties of three soil types, it will be of interest to consider their classification according to the Russian system. The present and past climate of Minnesota excludes the probability of any of these belonging to either Class I (Laterites and Red Earths) or (lass IV (Semi-arid and Arid Soils). Class $V$ (Soils formed under an excess of moisture) are represented only by the peat areas, which are not included in the present study, and Class VI (Alkali Soils), so far as now known, are entirely absent. This leaves the three types studied to be assigned to either of the two remaining classes, or partly to each, viz., Class III (Chernozem or Black Prairie Soils) and Class II (Podzols, Gray Forest Soils, Brown Earths and Degraded (hernozem).

The soils of Class III, true chernozems, are characterized in the surface layer by a content of organic carbon from 3.5 to 6.0 per cent and of nitrogen from 0.30 to 0.50 per cent $(21$, p. 318$)$, and a neutral reaction while the soil just below the dark colored portion effervesces with dilute acids. The data in Table $6+$ illustrates the character of typical Russian chernozems (21, p. 318). The soils of Class II, degraded chernozems, podzols and Brown Earths, are lower in organic carbon and nitrogen and are characterized by an acid reaction ( 16. p. 88) of the surface layer.

Table 6t.-Organic Constitucuts in the surface foot (approx.) of Russian ilernozem according to Kossoaitsch.

\begin{tabular}{|c|c|c|c|c|c|}
\hline & $\begin{array}{l}\text { Organic } \\
\text { matter }\end{array}$ & $\begin{array}{l}\text { Volatile } \\
\text { matter }\end{array}$ & $\begin{array}{l}\text { Organic } \\
\text { carbon* }\end{array}$ & Nitrogen & $\begin{array}{l}\text { Carbon } \\
\text { dioxide }\end{array}$ \\
\hline $\begin{array}{l}\text { Source of sample } \\
\text { Orël Mensk }\end{array}$ & per cent & per cent & per cent & percent & per cent \\
\hline $\begin{array}{l}\text { Urel, Mzensk Maloarcnang.... } \\
\text { IVoronesh, Bobrowsk ........ }\end{array}$ & 11.73 & $\begin{array}{l}13.20 \\
14.67\end{array}$ & $\begin{array}{l}0.39 \\
6.80\end{array}$ & 0.21 & 0.00 \\
\hline Ufa, Belebeiew ....... & 1672 & 19.56 & 9.69 & 0.83 & 2.2 .3 \\
\hline $\begin{array}{l}\text { Tobolisk, T Tukalinsk } \ldots \ldots \ldots \\
{ }^{*} \text { Organic Matter } \div 1.724 \text {. }\end{array}$ & 10.82 & 14.22 & 6.27 & 0.48 & 0.00 \\
\hline
\end{tabular}

If the Rice county soils (Table 65) the Fargo silt loan is clearly a true chernozem, the organic carbon and nitrogen falling well above the lower limits of the amounts of these constituents found in the chernozems of Russia. The Carrington silt loam also would be placed in this class if we considered only the proportions of organic carbon and nitrogen but, considering also the acid reaction of the surface layer and the non-calcereous nature of the subsoil immediately below this, we must regard it as being in the early stages of degradation.

Table 65.-Organic Constituents in the surface foot of Rice County soils. The data are az'erages of the ti'o corresponding drift samples.

\begin{tabular}{|c|c|c|c|c|c|}
\hline & Volatile & Organic & & Carbon & \\
\hline & $\begin{array}{l}\text { Matter } \\
\text { per cent }\end{array}$ & $\begin{array}{l}\text { Carhont } \\
\text { per cent }\end{array}$ & $\begin{array}{l}\text { Nitrogen] } \\
\text { per cent }\end{array}$ & $\begin{array}{l}\text { Dioxide } \\
\text { per cent }\end{array}$ & Reaction \\
\hline oton & 13.44 & 6.12 & .50 & .390 & v. sl. \\
\hline gton $S$ & 9.07 & 4.29 & .33 & .076 & med. \\
\hline ngton Loam & 5.25 & 2.25 & .19 & .077 & med. \\
\hline rshall Silt Loan & & 2.37 & .21 & $\cdots$ & med. \\
\hline
\end{tabular}

With the Carrington loam this process has advanced still further, placing the type clearly outside of the chernozems. The lower content of organic carbon and nitrogen and the acid reaction of the whole three foot-section slows that it belongs in Class II, and since it both lacks the characteristic podzol horizon $(16, \mathrm{p} .68)$, and compared with the Gray Forest Soils has a relatively high content of organic matter, it is to be considered as degraded chernozem. 


\section{SUMMARY.}

The thesis reports a study of the relation of the chemical composition and the physical properties of certain glacial soils of Minnesota to the age of the drift upon which they have been developed. The fields sampled are in Rice comnty, for which detailer glacial and soil surveys were avalable. This county is covered in part by the latest drift, the late Wisconsin, and the remainder l, the earliest exposed in Minnesota, the Kansan, both derived from practically the same sources and both originally highly calcareous from the surface downward while the southern tip of the deciduous forest, the l'igr Woods of Minnesota, extended down into it from the north and oecupied extensive areas on both sides of the dividing line between the two drift sheets.

On each of three types, the loam and the silt loam of the Carrington series and the silt loam of the Fargo series, representing, respectively, forest, upland grassland and lowland grassland, ten vircin fields were sampled, five on the Late $1 V$ isconsin and five on the Kansan.

All the fields sampled for the Carrington series were so situated as to have been fully exposed to the leaching effect of the portion of the precipitation passing from the surface into the deeper subsoil. The largo silt loam had developed under such poor natural drainage conditions that on many of the fields of this type there was little or no leaching to le expected.

The samples were taken to a depth of three feet in four separate sections, the first six inches, the second six inches, the second foot, and the third foot. In each field two sets were taken, these being composites from ten borings, and these two sets were combined to form the field simples. Complete analyses were made of the composites of the corresponding sections irom the five fields on the same type and the same drift, determinations of the phosphuric acid and carbon dioxide of all the field samples, and of the moisture equivalent, proportions of coarser rock fragments, nitrogen, color and reaction by various methods of all the set samples.

Five fields on a fourth soil type, Marshall silt loam, developed only upon the loess overlying the Kansan till, were included in the study and treated similarly insofar as part of the rleterminations are concerned. Three of these were still in virgin forest, and two were adjacent to land that had been cleared and given over to farming.

The texture of the fine earth of each type, as indicated by the moisture equivalent, is very similar on both drifts, but the proportion of coarser fragments is lower in the soils on the Kansan than in those on the Late Wisconsin. On the older formation, the original fragments of the softer rock (limestones, shales, and cherts), have almost entirely given way to the processes of weathering throughout a depth greater than three feet. 
A general relation was found to exist between the calcereousnes. and the texture, the finest txtured soils retaining the most carbonate and the coarsest the least.

With the two members of the Carrington series the degree of acidity, as indicated by three different methods, the litmus, the Truog and the ammonia, is the more pronounced on the Kansan. With the loam the carbon dioxide content is alike on both drifts, carbonates having been removed to a depth in excess of three feet, but with the silt loam, while on the Kansan the leaching has been as extensive as on the preceding type, considerable amounts of carbonate still remain in the third foot on the Late Wisconsin. On the fields of the Fargo type much less carbonate has been removed in the case of either drift and the reaction is less frequently acid on the Kansan than on the younger drift.

On the Kansan the calcium carbonate has been leached out to a depth greater than three feet on both the Carrington types, while on the Late Wisconsin the same is true for the Carrington loam but there is still an appreciable quantity in the third foot-section of the Carrington silt loam.

'The lime other than that in the form of carbonate is similar botli in arnount and distribution on the two Carrington types, but in the first two feet in the Fargo silt loam is considerably the higher on the Kansan.

The magnesia on each type is very similar from drift to drift, but is considerably higher in the fargo silt loam than in the other types.

The ratio of total lime to magnesia is slightly the ligher on the Late $W$ isconsin, this being due to the greater amount of calcium carbonate on the two of the types on the latter. The ratio of lime, in the form of silicate, to magnesia is very similar for each type from drift to drift, except with the Fargo silt loam where it is the lower on the younger formation.

The phosphoric acid is the higher on the Kansan, this being true for each of the three types. The amounts were determined in all ten fields on each type and with every type the individual fields on the Kansan showed an amount higher than or practically equal to that in the field on the Late Wisconsin richest in this constituent. On the two prairie types it shows a decrease from the surface downward, but with the forest type the vertical distribution is irregular.

Both potash and soda are very similar in corresponding sections from the two drifts except that with the Carrington loam the potash is slightly the higher and the soda distinctly the lower on the later glaciation.

In volatile matter the corresponding sections from the two drifts are very similar except that the Fargo silt loam in the surface six-inch 
section shows nearly twice an much on the Kansan ats on the Late Wisconsin.

The organic carbon, both in annount and distribution, is very similar from drift to drift with both of the Carrington types, but in the first two sections of the Fargo silt loan it is the higher on the Kansan, in this rescmbling the volatile matter. The foresterl fields show lower percentages than those on the grassland.

The distribution of nitrengen resembles that of organic carbon and volatile matter.

In relative darkness of color there is no difference between the Arifts in the case of any of the soil types, except in the surface six-inch section on the Carrington loam and the second and third foot-sections on the Fargo silt loan. With these the soil on the Iate Wisconsin is somewhat the darker.

If the three types of soils studied in detail were to be classified according to the Russian sistem, the Fargo silt loan would be considered a true chernozen, the Carrington silt loan a chcrnozem in the early stages of degradation, and the Carrington loam a degraded chernozem.

In general, the first three fect of soil on the well-rhained areas, originally similar in topography and profile and later coverce by the same type of regetation, are almost identical on the two drifts, which would suggest that the age of the most recent glaciation is so great as to have permitted the uniformity in climate and in vegetative cover. which has prevailed on the two sides of the dividing line in any locality, to almost completely obliterate the effects of the wreat ilifference in age.

It appears probable that the previously reported markeri differences in composition between the soils on the Kansan and on the Des Moines Lobe of the Late $\mathrm{W}$ isconsin are to be attributed to the effects of the differences in climate and vegetation that are involved when we employ data from large sections extending far to the east and to the west, respectively, of the contact line of the surface exposures of the two glacial sheets. It is probable that the differences which have been induced by differences in precipitation and vegetation within the area of any one glaciation nay be found to far exceed those attributable only to differences in the age of glaciation. 


\section{LITERATURE CITED.}

(1) Alway, F. J., and Blish, M. J.

1916. The loess soils of the Nebraska portion of the transition region: II. Humus, humus-nitrogen and color. In Soil Sci. $z^{\prime}, I$, no. 3 , p. $239-258,+$ fig.

(2) Alway, F. J., and McDole, G. R.

1916. The loess soils of the Nebraska portion of the transition region: I. Hygroscopicity, nitrogen, and organic carbon. In Soil Sci., i. 1, no. $3, p .197-238.2$ fig., $3 \mathrm{pl}$.

(3) Alway, F. J., and Rost, C. O.

1916. The vertical distribution of phosphorus in the surface soil of prairies. In Soil Sci., v. 2, no. 5, p. 493-497.

(4) Alway, F. J., and Rost, C. O.

1916. The loess soils of the Nebraska portion of the transition region: IV. Mechanical composition and inorganic constituents. In Soil Sci., i'. $T$, no. $5, p .705-136,2$ fig.

(5) Alway. F. J., and Russel, J. C.

1916. Use of the moisture equivalent for the indirect determination of the hygroscopic coefficient. In. Jour. Agr. Rescarch, r, 6, no. $22, p .833-8+6$.

(6) Briggs, L. J.. and McLane. J. W.

1907. The moisture equivalents of soils. U. S. Dept. Agr. Bur. Soils Bu1. 45, 23 p., 1 fig., 1 pl.

(7) Briggs, L. J., and McLaNe, J. W.

1910. Moisture equivalent determinations and their application. In Proc. Amer. Soc. Agron., v. 2, p. 138-147, 6 pl.

(8) Briggs, L. J., and Shantz, H. L.

1912. The wilting coefficient for different plants and its indirect determination. L. S. Dept. Agr. Bur. Plant Indus. Bul. 230, 83 p., 9 fig.. 2 pl.

(9) Brown, P. E.

1914. The fertility in lowa soils. Iowa Agr. Exp. Sta. Bul. 150, p. 89-152.

(10) Buchanan, H.

1807. Journey from Madras through Mysore. Canara, and Malabar. Vol. $I I$.

(11) BURKE, R. T. A., and KOLBE, L. A.

1911. Soil survey of Rice Cotunty, Minnesota. Advance sheets from field operations, 1909. 39 p., 1 fig., 1 map.

(12) Bureau of Solls.

1013. Soils of the United States. U. S. Dept. Agr. Bur. Soils Bul. 96. p. 791,13 fig., 2 pl.

(13) Chamberlin, T. C., and Salisbury, R. D.

1907. Geology, vol. III, 624 p., 576 figs. Holt \& Co., New York.

(14) Doкutschajew, V. V.

1883. Russian chermozem. St. Petersburg. 
(15) GLKKA, K.

1915. Pedologie. (Russ.) Petrograd.

(16) GunKa, K.

1914. Die typen cler Bodenbildung., 358 1., 65 fig., map. Berlin.

(17) HiLGarJ, E. WV

1892. A report un the relation of soils to climate. U. S. Dept. Agr. Weather Bur. Bul. 3.

(18) Hiliakd), E. WV

1895. Origin, value, and reclamation of alkali lands. In yearbook of U.S. Ilept. Agr., p. 103 .

(19) Hillekrand, W. F

1910. The andysis of silicate and carbonate rocks. U. S. Geol. Survey Bul. 422, 239 p., 27 fig.

(20) Hopkins, C. G., and Pettit, J. H.

1908. The fertility in Illinois soils. I11. Agr. Exp. Sta. Bul. 123, p. 187294. $8 \mathrm{pl}$.

(21) Kossumitsch, P.

1912. Die Swartyerde (Tschernosiom). In Internat. Mitt. Bodenk, Bd. $I, p .199-351$.

(22) LEIERETT, FRANK.

1910. Comparison of North American and European glacial deposits. In \%eilschrift für Gictscherkunde. ₹'. If. p. 2.1I-3I6, 5 fig., $5 \mathrm{pl}$.

(23) I.ETERETT. lik.INK, and S.IRDeson, F. W.

1917. Surface formations and agricultural conditions of northeastern Minneiota. Minnesota (ieological Survey Bul. 13, p. 72, 15 fig.

(2t) L,OEN, OSCAR

1901. The relation of lime and magnesia to plant growth. I. Liming of soils from a plysiological standpoint. In U.S. Dept. Agr. Bur. Plant Indus. Bul. I. p. I-35.

(25) MCMLLLER, P. R.

1915. A study of the glacial and loessial soils of the most southerly tier of counties in Minnesota. Thesis, University of Minnesota.

(26) MAY, 1), W.

1901. The relation of lime and magnesia to plant growth. II. ExperiInental study of the relation of lime and nuaguesia to plant growth. In U. S. Dept. Agr. Bur. Plant Indus. Bul. 1, p. 37-53, $3 \mathrm{pl}$.

(2T) RAMANN E.

1911. Bodenkunde, ed. 3, p. 619,63 fig.

(28) Rost, Clayton O.

1917. The determination of soil phosphorus. In Soil Sri., r. t, no. t, $\mathrm{r}$. 295-3II.

(29) Smith, J. LaWrence.

1871. On the determination of the alkalies in silicates ignited with carbonate of line and sal ammoniac. In Am. Jour. Sci., 2nd ser.,

(30) TRUOG, E.

1915. A new test for soil acidity. Wisconsin Agr. Exp. Sta. Bul. 294, 15 p., 3 fig., 1 cl.

(31) WaRTH, F. J.

1903. The composition of Indian laterite. In Geological Magazine. v. 4, no. 10, h. $154-159$.

(32) Washington, H. S.

1910. Manual of chemical analysis of rocks. Ed. 2, 200 p. New York.

(33) Wheeler, H. J., Hartwell, B. L., and SARGent, C. L.

1899. Chemical methods for ascertaining the lime requirement of soils. Rhode Island Agr. Exp. Sta. Bul. 62. 


\section{BIOGRAPHICAL SKETCH.}

Clayton Ord Rost was born near Ord, Valley county, Nebraska, on Nov. 24, 1885. His elementary education was secured in public schools near Nebraska City and at Orchard, Nebr., where he completed the ninth grade. Later he attended the Nebraska Normal College at Wayne and the Neluraska State Normal College at Peru, entering the University of Nebraska in 1908. In 1911 he received the degree of Bachelor of Science with his major in chemistry, and in 1912 the degree of Master of Arts with his major in agricultural chemistry.

From November, 1912, to August, 1913, he was research assistant in agricultural chemistry in the Nebraska Agricultural Experiment Station. In August, 1913, he was appointed assistant chemist in the Division of Soils of the Agricultural Experiment Station, University of Minnesota. He continued advanced work in the Graduate School of the same University, completing the residence and course work for the degree of Doctor of Philosophy in June, 1918.

Major-Soil Chemistry.

Minor-Geology (petrography).

Thesis-Parallelism of the soils developed on the Gray Drifts of Minnesota.

Phi Beta Kappa.

Signa Xi.

\section{Publications}

The determination of total manganese in soils. (With R. A. Gortner.) In Jour. Indus. Eng. Chem. v. 4, No. 7 (1912), p. 522-524.

The loess soils of the Nebraska portion of the transition region; IV. Mechanical composition and inorganic constituents. (With F. J. Alway.) In Soil Science, v. 1. No. 5 (1916), p. 405-437, 2 fig.

The vertical distribution of phosphorus in the urface soil of prairies. (With li. I. Alway.) In Soil Science, v. 2, No. 5 (1916), p. 493-498.

The loess soils of the Nebraska portion of the transition region: VI. The relative "rawness" of the subsoils. (With F. J. A!way and G. R. McDole.) In Soil Science, v. 3, No. 1 (1917) p. 9-36, 9 plates, 4 figs.

The determination of soil phosphorus. In Soil Science, v. 4, No. + (1917), p. 295-312.

Determination of lime and phosphoric acid in peat soils: Comparison of Jönköping with Bremen method. (With F. C. Clapp.) In Soil Science, v. 5, No. 3 (1918), p. 213-219. 

ALL BOOKS ARE SUBJECT TO RECALL RENEW BOOKS BY CALLING 642-3405

\section{DUE AS STAMPED BELOW}

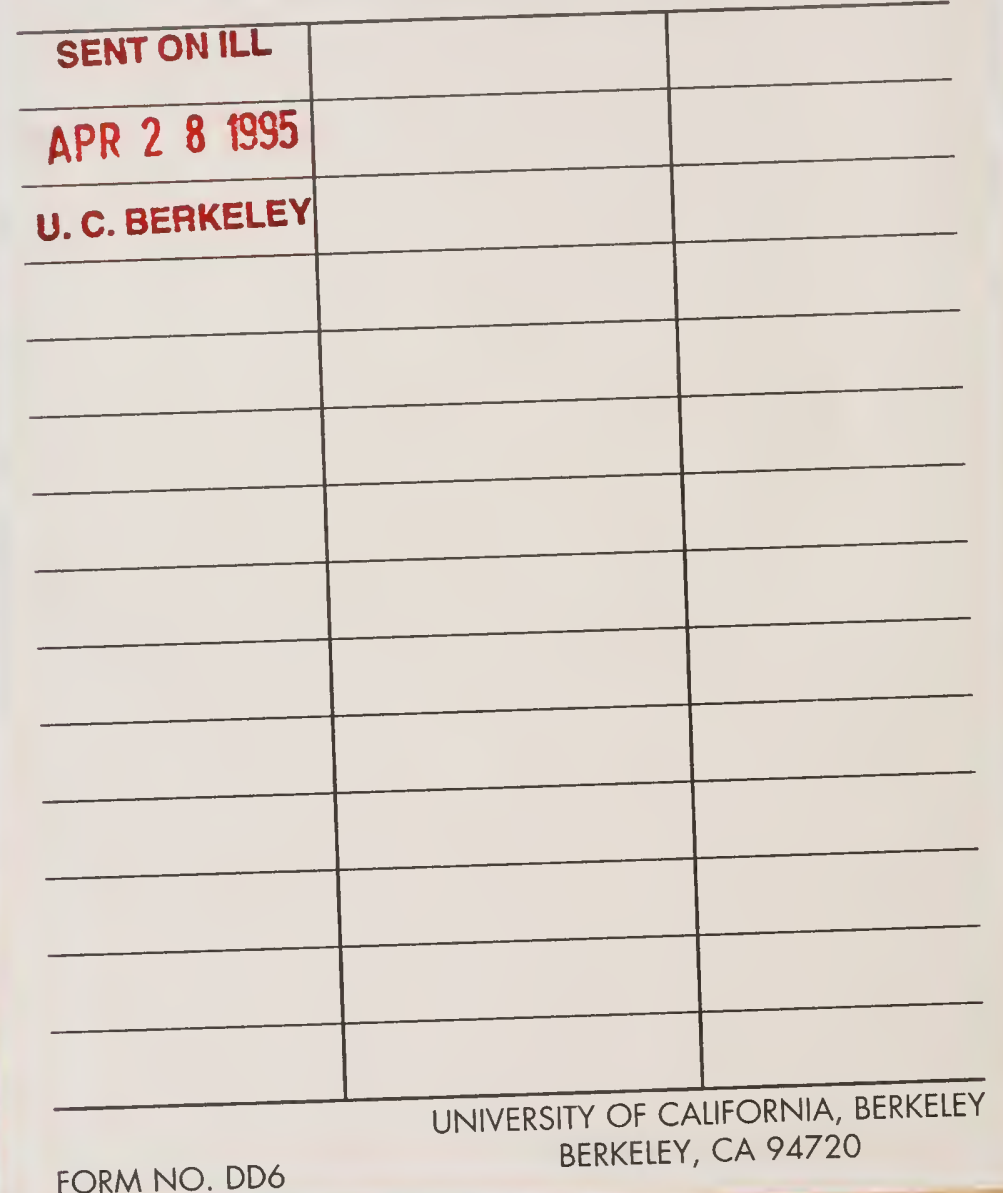




\section{8}

UNIVERSITY OF CALIFORNIA LIBRARY 
